UNIVERSIDADE DE SÃO PAULO

USP

Lucas Matteocci Lopes

VIOLÊNCIA, SACRIFÍCIO E PODER

- UMA LEITURA GIRARDIANA DE TENDÊNCIAS DA LITERATURA OCIDENTAL

VERSÃO CORRIGIDA

Mestrado em Teoria Literária e Literatura Comparada

São Paulo

2019 
Lucas Matteocci Lopes

\section{VIOLÊNCIA, SACRIFÍCIO E PODER \\ - UMA ANÁLISE GIRARDIANA DE TENDÊNCIAS DA LITERATURA OCIDENTAL VERSÃO CORRIGIDA}

Dissertação apresentado à Banca examinadora da USP Universidade de são Paulo -, como exigência parcial para obtenção do título de Mestre em Teoria Literária e Literatura Comparada, sob a orientação do Prof. Dr. Marcus Vinícius Mazzari

São Paulo 
Autorizo a reprodução e divulgação total ou parcial deste trabalho, por qualquer meio convencional ou eletrônico, para fins de estudo e pesquisa, desde que citada a fonte.

Catalogação na Publicação

Faculdade de Filosofia, Letriça e Ciências Humanas da Universidade de São Paulo

Lopes, Lucas Matteoce1
V1olênc1a, Sacrific10 e Poder - Uma Le1tura G1rardiana de Tendencias da Literatura oc1dental / Lucas Matteocc1 Lopes ; or1entador Marcus V1n1c1us Mazzar1. - Så Paulo, 2019.

D1saertaçăo (Mestrado) - Faculdade de F1losof1a, Letras e c1encias Humanas da Universidade de Sao comparada. Area de concentraçăo: Teor1a Literár1a e L1teratura comparada.

1. Literatura Comparada. 2. Sacrifíc10. 3. Poder. II. Título. 


\section{ENTREGA DO EXEMPLAR CORRIGIDO DA}

\section{DISSERTAĈ̃O/TESE}

\section{Termo de Ciência e Concordância do (a) orientador (a)}

Nome do (a) aluno (a): Lucas Matteocci Lopes

Data da defesa: 18/11/2019

Nome do Prof. (a) orientador (a): Marcus Vinicius Mazzari

Nos termos da legislação vigente, declaro ESTAR CIENTE do conteúdo deste EXEMPLAR CORRIGIDO elaborado em atenção às sugestões dos membros da comissão Julgadora na sessão de defesa do trabalho, manifestando-me plenamente favorável ao seu encaminhamento e publicação no Portal Digital de Teses da USP.

São Paulo, 11 /02 /2020

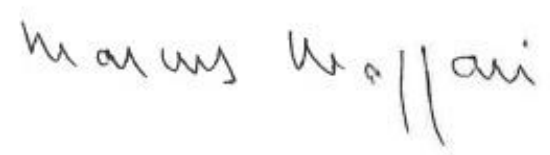

Prof. Dr. Marcus V. Mazzari

DTLLC

2800416 


\section{Agradecimentos}

Agradeço a todos que possibilitaram e contribuíram para o desenvolvimento deste trabalho.

A meu orientador, Marcus Vinicius Mazzari, que aceitou este projeto, ainda mal definido, e me deu liberdade para desenvolvê-lo. Também pelas importantes contribuições, pelas profundas e estimulantes aulas durante a graduação e a pósgraduação. E não menos por ter me salvado em questões burocráticas, para as quais não apresento grande talento.

A meus professores de graduação e pós-graduação, em diálogo implícito com os quais produzi durante este tempo de formação todos os trabalhos em que se colocavam e nos quais procurei desenvolver a maioria das questões trabalhadas nesta dissertação. São numerosos demais para receberem o merecido agradecimento nominal, mas gostaria de destacar os professores: Ana Paula Pacheco, que me orientou em minha iniciação científica, em que já começava o diálogo com a teoria de René Girard; Christian Werner, para o curso do qual redigi inicialmente o trecho desta pesquisa que trata de Odisseu; e aos professores Yudith Rosenbaum e Alexandre Bebiano, que aceitaram participar de minha banca de qualificação e muito contribuíram com seus comentários e questionamentos. Igualmente agradeço aos professores que compuseram a banca examinadora: João Cezar de Castro Rocha, profundo conhecedor da obra de Girard; Priscila Figueiredo; e novamente Alexandre Bebiano; todos os quais me permitiram uma maior compreensão de meu trabalho e contribuíram para a reflexão acerca de sua possível continuidade.

Agradeço a Maurício Fraya, amigo e colega que, após a defesa, se ofereceu para revisar a dissertação, com prazo limitado, e contribuiu para suprimir muitas imperfeições textuais, não sendo responsável por aquelas que possam permanecer. Também sou grato a ele pelo diálogo constante ao longo da graduação e da pósgraduação.

Agradeço também a todos aqueles que me emprestaram sua visão para a leitura e o estudo ao longo destes anos, tornando ainda mais verdadeiro o aspecto de diálogo que nem sempre nos recordamos ser intrínseco a este ato que em nossa 
cultura tornou-se solitário, mas que para mim sempre envolveu a presença física de um outro. Particularmente a Cristiane Cardoso de Melo, que me acompanhou do primário até a conclusão do ensino médio, e a Irene Leonel, que por pura amizade dedicou inúmeros fins de semana a partilhar comigo o prazer da literatura e tanto me ensinou em diversos sentidos.

Nesse sentido, agradeço ainda aos sites Litteratureaudio e Librivox, bem como a seus voluntários, que se dedicam a tornar acessível a tradição literária por meio de seus audiolivros, sem o que teria sido impossível o trabalho autônomo com muitas das obras aqui estudadas.

Agradeço também a minha família, e muito particularmente a meus pais: Paulo Cesar Carneiro Lopes e Nivea Maria Matteocci, professores que sempre me ensinaram a amar a literatura e me ensinaram a saber que ela é mais (ainda mais) do que um grande prazer; me apontaram caminhos que me deixaram livre para seguir ao mesmo tempo que sempre me apoiaram de todas as maneira ao trilhá-los.

Agradeço à Universidade de São Paulo e à CAPES, que me outorgaram uma bolsa de estudos que me permitiu levar adiante esta pesquisa, direito que, infelizmente, parece estar em vias de se tornar um privilégio cada vez mais raro.

Haveria muitos mais a agradecer. Todos os meus amigos, colegas e todos aqueles com os quais, de um modo ou de outro, tive contato ao longo destes anos, pois, afinal, tudo faz parte de nosso caminho e contribui com nosso esforço de buscar a verdade, sabendo não sermos seus donos. Sou muito grato a todos. 


\section{Resumo}

Este trabalho procura investigar sob que formas fenômenos sacrificiais figuram na tradição literária, os caminhos pelos quais eles vêm a se fazer presentes nela e sua relação com o sacrificialismo extraliterário. Para isso, a principal referência teórica é o pensamento de René Girard, que postula a resolução de crises cíclicas de violência interna no seio das mais diversas sociedades através do sacrifício de um bode expiatório como o eixo que dá origem à cultura e estrutura todas as comunidades humanas.

Esta abordagem não é de forma alguma extraliterária, pois em diversas obras o sacrifício ocupa um papel central na organização de seu enredo e na construção dos personagens, além de se relacionar com o próprio estilo do texto. Sua presença,

porém, é em geral sutil, raramente correspondendo ao esquema básico da crise sacrificial proposto por Girard, do mesmo modo que, fora da literatura, este se manifesta também sob formas as mais diversas.

Na literatura épica, o sacrificialismo está ligado aos valores guerreiros e imperialistas próprios às sociedades que representam e o sacrifício tende a se dividir em dois: o louvável sacrifício do herói e o sacrifício punitivo ou simplesmente inevitável de seus antagonistas. Na literatura cômica, o riso zombeteiro se volta contra as vítimas típicas da sociedade, quer sejam os marginalizados quer os poderosos cuja queda cíclica renova e reforça as estruturas de poder que representam. Na literatura que retrata as tendências revolucionárias, costuma haver uma denúncia do sacrifício constituído pela opressão social, mas pode haver o risco de queda em um novo sacrificialismo quer na ideia de autossacrifício revolucionário, quer na ideia de eliminação dos opositores desta revolução.

Embora esta abordagem destaque um aspecto de violência presente na literatura, mais frequentemente de modo acrítico, isso não implica sua condenação. Trata-se apenas de ressaltar a ambiguidade de um de seus aspectos constitutivos, reforçando sua complexidade e sua riqueza enquanto manifestação essencial da cultura humana. 
Palavras-chave: Tradição literária; literatura comparada; sacrifício; poder; René Girard

\begin{abstract}
This research seeks to investigate in what forms sacrificial phenomena are presented in the literary tradition, the ways by which they become present in it, and their relation to extraliterary sacrificialism. For this, the main theoretical reference is the thought of René Girard, who postulates the resolution of cyclical crises of internal violence within the most diverse societies through the sacrifice of a scapegoat as the axis that gives rise to culture and structures all communities.

This approach is by no means extra-literary, for in many literary works sacrifice plays a central role in the organization of its plot and in the construction of the characters, in addition to its relationship with the style of the text itself. Its presence, however, is generally subtle, rarely corresponding to the basic scheme of the sacrificial crisis proposed by Girard, just as, outside the literature, it also manifests itself in the most diverse forms.

In epic literature, sacrificialism is linked to the warrior and imperialist values proper to the societies they represent, and sacrifice tends to be divided into two: the praiseworthy sacrifice of the hero and the punitive or simply unavoidable sacrifice of its antagonists. In comic literature, mocking laughter turns against the typical victims of society, whether marginalized or powerful whose cyclical downfall renews and reinforces the power structures they represent. In literature portraying revolutionary tendencies, there is often a denunciation of social oppression, but there may be a risk of falling into a new sacrificialism either in the idea of revolutionary self-sacrifice or in the idea of eliminating opponents of this revolution.

Although this approach highlights an aspect of violence present in the literature, most often in an uncritical way, it does not imply its condemnation. It is just a matter of stressing the ambiguity of one of its constitutive aspects, reinforcing its complexity and richness as an essential manifestation of human culture.
\end{abstract}

Keywords: Literary tradition; comparative literature; sacrifice; power; René Girard 


\section{ÍNDICE}

Introdução

Apresentação........................................................................................11

Introdução teórica.......................................................................................16

1 Concepção filosófica...............................................................16

2 Concepção antropológica.............................................................19

2.1 - Mimetismo e gênese da cultura.................................19

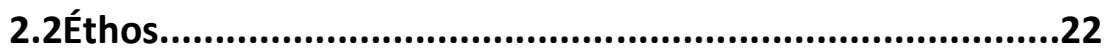

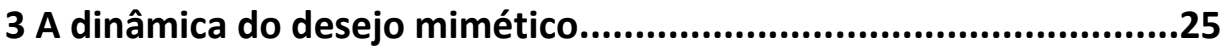

3.1 - Mediação externa e constituição da subjetividade..........25

3.2 - Mediação interna.........................................................29

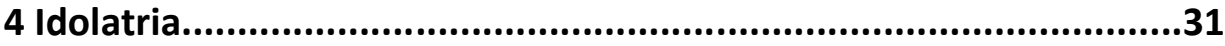

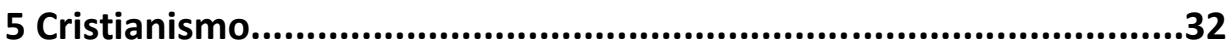

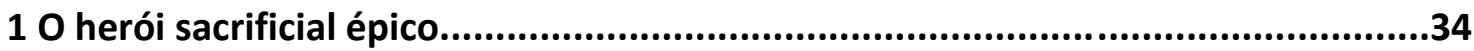

1. Surgimento do mito do herói .............................................................34

2. Deslocamentos sacrificiais em Gilgamesh..............................................38

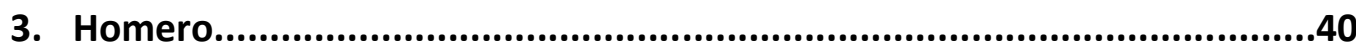

3.1.Heróis homéricos..........................................................................40

3.2 Cara ou coroa: Odisseu, Tersites e Iro..............................................43

4. Tendências sacrificiais na tradição épica pós-homérica: o sacrifício imperial e o sacrifício dos sacrificadores................................................51

5. O sacrificialismo na épica cristã colonialista........................................54

6. La chanson de Roland.........................................................................57

Apêndice: o sacrifício e a glória.............................................................68

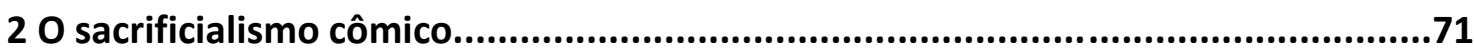

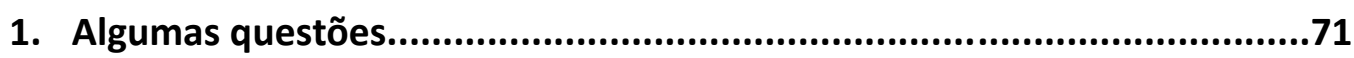


2. A manipulação dos mecanismos sacrificiais em Aristófanes.....................73

3. Enfraquecimento do coletivo na Comédia Nova......................................78

4. Carnavalização, transformação e conservadorismo em Rabelais...............79

4.1 0 sacrificialismo na cultura carnavalesca...................................79

4.20 sacrifício na ficção de Rabelais.............................................85

3 Represão, revolução e sacrifício ......................................................................99

10 sacrificialismo repressivo e o revolucionário.....................................100

2 Conflitos sociais e os ciclos sacrificiais em Germinal .............................111

3 Denúncia e adesão ao sacrificialismo em Brecht...................................131

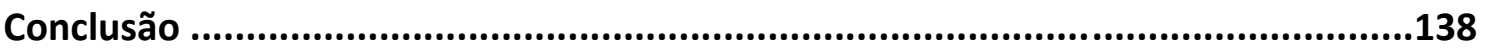

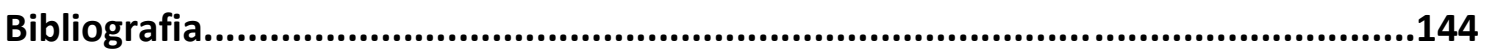




\section{Introdução}

\section{Apresentação}

A violência e o poder, duas palavras fortes, cuja relação mútua não é qualquer segredo, embora possa ser abordada pelos mais diversos ângulos. Que o emprego da violência possa contribuir para a conquista e a defesa do poder é bastante evidente, e muita polêmica pode ser criada acerca da possibilidade de uma sociedade que se sustente sem apoiar-se neste mesmo poder violentamente estruturado. Entretanto, e tampouco isso será novidade para a maioria, não é apenas, e talvez nem mesmo primordialmente, da violência coercitiva, diretamente empregada para coibir e governar indivíduos e grupos, que se alimentam o poder e a ordem vigentes em uma sociedade, como se se tratasse de algo imposto de fora àqueles que a compõem.

É principalmente a violência intrínseca a cada indivíduo e à dinâmica de seu relacionamento coletivo que, ao se organizar e receber um direcionamento adequado, cria a unidade e a paz mínima necessária para que uma comunidade humana se mantenha como tal, e, dentro da teoria de René Girard, o que permite a conversão desta violência, que em si deveria ser um fator de desordem e dissolução social, na principal força de união de toda coletividade é o sacrifício. Assim temos a terceira palavra que compõe o título deste trabalho e que constitui o elo essencial entre as duas outras.

De que se trata, para Girard, este "sacrifício" é uma das principais questões que este trabalho procura discutir, ou melhor dizendo: não apenas o que é o sacrifício para o autor francês, mas também a que outros fenômenos poderíamos aplicar produtivamente o mesmo nome nos servindo de sua teoria, mesmo quando não se trata exatamente daquilo a que ele próprio aplica o conceito de modo mais sistemático. Com isto em vista, inicialmente esta pesquisa pretendia fornecer uma espécie de tipologia, examinando exemplos diversos de obras literárias que representassem a temática sacrificial. À medida, porém, que o trabalho se definia com maior clareza, o que acabou se consolidando como objeto da pesquisa foram 
exatamente os casos em que as relações do sacrifício com a estruturação do poder político nas sociedades de que tratavam as obras literárias apareciam mais diretamente, e assim as análises se dividiram em três capítulos, cada um abordando um "gênero" distinto: a épica, a literatura cômica, e a literatura que se liga à questão da revolução.

A maior parte desta introdução será dedicada à discussão da teoria de Girard e a uma tentativa de articulá-la com a visão filosófica mais ampla que orientou o desenvolvimento deste trabalho, por isso não a apresentarei por ora com um mínimo de profundidade. Apenas esclarecerei, para o leitor inteiramente sem familiaridade com ela, que para Girard o sacrifício é, basicamente, o processo pelo qual a violência coletiva da comunidade, no contexto de uma crise em que seus membros se voltam uns contra os outros, termina por se concentrar sobre um indivíduo único, com a morte ou expulsão do qual a paz torna a reinar. Este esquema simples, porém, pode assumir formas muito diversas e frequentemente difíceis de identificar; as diferenças de um caso para outro sendo muito significativas.

Como o sacrifício vem a figurar nas obras literárias é algo que também será mais discutido adiante, mas agora apresentarei brevemente aquilo com que me deparei nas análises que compõem os três capítulos principais desta pesquisa.

À primeira vista poderia parecer pouco evidente minha afirmação de que os três gêneros estudados representam de modo particularmente perceptível a ligação entre o sacrifício e o poder, mas creio que isto ficará mais claro. A literatura épica, de tema heroico e bélico, em geral dá representação direta à ideologia imperialista das sociedades em que foram criadas suas obras, apresentando sem grandes disfarces sua tomada do inimigo como bode expiatório, em torno da luta contra o qual se constitui sua própria unidade. Também indisfarçado é o papel do ideal de autossacrifício dos guerreiros, o que de um lado proporciona sua adesão entusiástica aos perigos da guerra, de outro fornecendo como mais um elemento de unidade social o culto comum aos heróis mortos em batalha.

Estas são, de fato, manifestações de sacrificialismo que se afastam em grande medida do modelo básico do sacrifício tão sumariamente apresentado acima. Um dos 
motivos pelos quais podemos considerá-las como "sacrifícios" é sua ligação à violência coletiva e seus efeitos no interior da comunidade. Mais que isso, a literatura épica, originando-se de mitos tradicionais ou, em casos mais tardios, tratando assuntos históricos segundo seus modelos, nos apresenta heróis individuais que assumem de forma bastante forte o papel do bode expiatório morto na crise sacrificial, já que, na teoria girardiana, é da transfiguração de tais crises que se originam os mitos.

As formas muito distintas e variadas pelas quais estes elementos se fazem presentes nas obras concretas se verá nas análises. Neste capítulo em particular, o número de textos estudados é grande, e talvez pareça excessivo à primeira vista. Espero que esta impressão se desfaça durante a leitura, tendo em mente que elas não pretendem nem remotamente ser uma análise em profundidade das obras como um todo, mas visam apenas destacar um de seus aspectos que julgo relevante. Além disso, inicialmente não pretendia "alongar-me" - por pouco que o tenha feito se pensarmos no merecimento de cada obra - ao discutir a maioria dos textos citados, mas apenas exemplificar algum ponto da reflexão teórica que desenvolvia, mas acabava me deixando levar e terminei por adotá-lo como "método".

Assim, terminei por abordar, a grandes passadas, de Gilgamesh aos Lusíadas, desenvolvendo mais longamente a análise de La chanson de Roland, a que inicialmente iria me dedicar. Também aproveitei neste capítulo um trabalho elaborado durante a graduação para o professor Christian Werner sobre o personagem Odisseu na tradição homérica - o subtítulo que terminou por constituir se destacando um pouco do restante do capítulo -, e acabei incluindo como um anexo uma reflexão teórica sobre a Glória, elaborada a partir do livro de Agamben, O Reino e a Glória a qual julguei relevante para o tema, mas que não consegui encaixar de modo mais orgânico no corpo do capítulo.

Quanto à literatura cômica, muitas vezes sua ligação com o sacrificial não é menor. Embora muitos tendam a considerar o humor em si mesmo libertário e revolucionário, com grande frequência este consiste em designar um indivíduo ou grupo como alvo da zombaria unânime e cruel de uma comunidade, cujos laços se fortalecem graças ao escárnio comum à sua vítima desprezada. Os objetos da 
zombaria, ademais, são frequentemente escolhidos entre aqueles que por uma razão ou outra tendem prioritariamente a se tornarem os bodes expiatórios de perseguições mais diretamente violentas, de outro lado estas sendo frequentemente acompanhadas pelo escárnio cruel a suas vítimas.

Um ponto importante em que a questão do cômico se liga à do poder é sua estreita relação com as festas carnavalescas que, segundo a teoria girardiana, são uma das principais formas de reprodução ritual da crise sacrificial, suspendendo temporariamente como ela as hierarquias e regras de uma comunidade, para então reafirmar a ordem com um novo sacrifício. Além disso, o herói cômico é em grande medida uma contraparte do herói épico, carregando de modo mais visível do que este sinais negativos - ainda que muitas vezes recebendo um tratamento simpático enquanto circunscritos ao âmbito do cômico - que o relacionam ao bode expiatório, culpabilizado e perseguido, transfigurado pela narração mítica.

Neste capítulo as obras analisadas são menos numerosas, e foram escolhidas entre as que colocam de modo mais "direto" a relação do riso com a disputa pelo poder. São elas A Paz, de Aristófanes, em que podemos ver muito da fervilhante dinâmica sacrificial que atuava na democracia ateniense; e os romances de Rabelais, em que é de particular interesse o tema do destronamento; além de haver uma breve discussão de traços da Comédia Nova.

É no terceiro capítulo que a questão do poder entra de modo mais evidente. A discussão contemporânea, tão forte nos séculos XIX e XX, acerca da possibilidade e justiça da transformação das estruturas sociais por meio da revolução, coloca de modo bastante visível o problema do emprego da violência para tomar ou manter o poder e, assim, o dos sacrifícios que qualquer destas posições exigem.

Do lado do discurso conservador, o sacrifício pode ser visto tanto na defesa de que a exploração constante de largas parcelas da sociedade é necessária para a manutenção da ordem estabelecida, quanto na ideia de que qualquer tentativa de abalá-la deve ser reprimida violentamente, o que torna as vítimas desta exploração e desta repressão em bodes expiatórios, cujo sacrifício é necessário para a manutenção do status quo. Do lado do discurso revolucionário, por sua vez, a ideia da obrigação do 
autossacrifício em nome da revolução é extremamente forte, podendo assumir formas muito problemáticas, assim como é evidente o caráter sacrificial da ideia de eliminar violentamente todo aquele que pudesse ser um empecilho para a transformação social almejada.

É interessante, ainda, acerca deste tema, notar que ao discuti-lo, frequentemente se emprega metáforas e aproximações com o campo religioso. Isto revela uma percepção intuitiva, no contexto secularizado em que se dá a discussão destas questões, da semelhança entre pontos negativos do religioso, da sociedade secular já estabelecida e dos movimentos revolucionários, a qual, de nosso ponto de vista, reside exatamente no sacrificialismo que estrutura a todos.

As obras analisadas neste capítulo são: Germinal, de Zola, na qual a representação crítica tanto da sociedade burguesa e seu conservadorismo quanto dos movimentos de massa de tendências inconsistentemente revolucionárias dos trabalhadores explorados mostra de modo interessante o sacrificialismo em ambos; e algumas obras de Brecht (em particular A Santa Joana dos matadouros), nas quais o sacrificialismo do sistema capitalista é claramente denunciado, ao mesmo tempo que o sacrificialismo revolucionário a que o próprio autor adere de modo muitas vezes acrítico se revela, pondo à luz, também, complexos mecanismos ideológicos que podemos associar ao ocultamento mitológico do sacrifício.

A discussão destas questões é bastante difícil, pois não se trata de modo algum de condenar por seu sacrificialismo as obras literárias aqui estudadas, em geral de imenso valor artístico. Trata-se, apenas, de destacar sua relação inconsciente com esta dinâmica universal das sociedades humanas, a qual, na verdade, tem grande importância em sua composição artística. De um ponto de vista ético, cabe no máximo ressaltar avanços ou retrocessos no modo de lidar com essa violência humana quase iniludível, os quais se refletem em cada obra particular.

Antes de passar à apresentação dos pressupostos teóricos que guiaram este trabalho, para que o leitor possa se situar melhor ao acompanhá-lo, cabe esclarecer mais alguns detalhes práticos. Para qualquer um que não superestime imensamente as capacidades do autor deste trabalho é fácil supor que a maioria das obras estudadas 
não foram lidas no original. Embora, é claro, a análise do texto original seja essencial para uma interpretação verdadeiramente profunda, não acredito que isto prejudique de modo fundamental seu estudo no nível a que se propõe esta pesquisa.

Outra particularidade que talvez causasse alguma estranheza é o fato de que me refiro a versões em áudio da maior parte das obras literárias citadas. Isto se deve a uma necessidade prática, pois, sendo deficiente visual, este recurso era preciso para que pudesse ter acesso às obras e voltar autonomamente aos trechos que precisava revisitar durante a análise. Também a isso se deve o fato de que não faço citações textuais dos trechos analisados, pois seria difícil para mim localizá-los e transcrevê-los palavra por palavra. Disso, entretanto, talvez resulte até mesmo algo de positivo para o trabalho, já que, embora eu reconheça as vantagens de ter à mão o texto analisado pelo intérprete, as seleções descontextualizadas que este possa fazer não são necessariamente menos falseadoras que paráfrases bem intencionadas; além de que, para ressaltar o ponto de vista sobre o qual o estudioso de um texto gostaria de chamar a atenção do leitor, é quase sempre necessário parafrasear, em alguma medida, o mesmo trecho que foi citado, o que não conviria para um trabalho desta natureza, tornando-o excessivamente extenso para uma pesquisa de mestrado.

Sem mais delongas, passemos à segunda parte desta introdução.

\section{Introdução teórica}

\section{1 - Concepção filosófica}

Começarei com uma declaração não argumentativa da minha concepção filosófica, a qual justifica a opção teórica que orientará a presente pesquisa. Por seu próprio caráter não argumentativo, tal posição parecerá necessariamente ingênua, tanto mais por não estar entre as mais em voga no presente momento do mundo acadêmico. Ainda assim, ela é assumida por muitos dos grandes pensadores da atualidade ${ }^{1}$ e 0 fato de que aqui não possa ser melhor defendida não deve fazer com que a descartem

\footnotetext{
${ }^{1}$ Ver, por exemplo: HÖSLE, Vittorio. L'idealisme objectif. Paris: Les Éditions Du Cerf, 2001; VAZ, Henrique C. de Lima. Escritos de Filosofia II: ética e cultura. São Paulo, Edições Loyola:1988; OLIVEIRA, Manfredo Araújo de. Ética, direito e Democracia. São Paulo: Paulus, 2010.
} 
com demasiada facilidade, sendo, como qualquer posição teórica, a seus maiores expositores que qualquer crítica séria deve remeter. Os pontos mais diretamente ligados ao objeto deste trabalho serão abordados com alguma profundidade mais e não necessariamente dependem da aceitação do todo da visão teórica em que se inscrevem para possuírem validade. Entretanto, acredito que não colocar com clareza a base de que partem consistiria em um erro.

A realidade é una e a filosofia é o pensamento do todo. Dizer que a realidade é una não significa negar a multiplicidade, mas reconhecê-la como manifestações distintas do Ser que se aliena nos entes, os quais, por sua vez, não são autônomos e não estão isolados, mas fazem parte de um sistema dinâmico em que tudo se relaciona com tudo e está sempre em transformação ao relacionar-se, sendo nisto que consiste a dialética.

Deste modo, cada ciência particular é o estudo de dado aspecto deste sistema, isolado de modo sempre algo arbitrário, mas permitindo compreender melhor este aspecto isolado. Assim como, na realidade, cada um destes aspectos é manifestação do todo em seu processo dialético e permanece parte da totalidade do mundo fenomênico em cada um de seus momentos sincrônicos que podem ser isolados, os resultados a que chegam as ciências particulares podem ser reinscritos por um esforço conceitual em um quadro teórico filosófico que propõe uma visão do todo, sendo o preenchimento de suas lacunas e o seu detalhamento.

Assim, de um ponto de vista filosófico dialético, poderíamos não hierarquizar, mas propor uma organização das ciências particulares segundo a precedência do aspecto do todo que tratam no desenrolar do processo diacrônico dialético. Cada um destes aspectos do todo permanece a atuar nos desenvolvimentos posteriores do mundo fenomênico e, idealmente, as ciências que abordam estes últimos deveriam levá-los em conta. Fazer isso de modo completo, no entanto, é impossível e até que ponto isto pode ser feito de modo relevante é uma questão que cada pesquisador deve buscar resolver segundo as exigências de sua pesquisa.

Assim, não de um ponto de vista epistemológico, mas de acordo com o critério de precedência acima sugerido pode-se apresentar a seguinte lista de ciências 
(evidentemente lacunar) relevantes para esta pesquisa, a própria existência do objeto de algumas sendo questionada em certos quadros teóricos: teologia; metafísica; física (entendida de modo a compreender desde a física subatômica, passando pela química até a constituição daquilo que entendemos como objetos e suas relações puramente materiais); biologia (sendo de particular importância o estudo do processo evolucionário dos seres vivos); a antropologia (entendida como estudo das constantes no ser humano que se manifestam sob diversas formas); a sociologia (entendida como o estudo de cada sociedade em particular); e a crítica literária. Como mencionado, esta lista é lacunar. Como também mencionado, o objeto de cada uma destas ciências é um recorte arbitrário e em cada uma delas muitos outros poderiam ser feitos, entre estes nem todos abordando aspectos sucessivos do desenvolvimento do todo, mas muitas vezes paralelos.

A crítica literária, assim, surge como um desenvolvimento da sociologia, não por ser considerada um de seus ramos ou dever ser praticada segundo sua metodologia, mas pelo fato de a literatura ser um produto humano e como tal só poder surgir no contexto de culturas particulares. De acordo com o que precede, o estudo da literatura deve, é claro, centrar-se nela enquanto literatura, mas nisso só tem a ganhar ao incluir (na justa medida) o saber fornecido pelas demais ciências.

Enquanto fenômeno, a literatura é uma produção humana, da qual qualquer manifestação particular se dá em dada sociedade particular, sendo determinada por ela. Esta sociedade, por sua vez, será uma manifestação concreta das possibilidades antropológicas, que, de um lado, dependem da base biológica humana e, de outro, apenas têm existência nas diversas sociedades particulares.

Por seu caráter representativo, a literatura sempre apresenta figuras humanas ou antropomorfizadas ${ }^{2}$ relacionando-se umas com as outras. Deste modo, quer a proponham como uma visão aplicável à realidade extraliterária, quer não, toda obra apresenta mais ou menos explicitamente uma visão sobre o humano e as formas de relacionamento possíveis entre os indivíduos em sociedade.

\footnotetext{
${ }^{2}$ Há obras que enfocam quase exclusivamente o aspecto formal da literatura, evitando seu caráter de representação. Estas exceções, porém, são bastante tardias e em geral o fazem de modo programático, como uma oposição à tendência natural de representação, o que as torna, de todo modo, inseparáveis dela.
} 
Assim, podemos considerar que toda obra, além de ser um produto social, portanto analisável em termos sociológicos e antropológicos, se estrutura a partir de uma hipótese antropológica e sociológica, intrínseca a ela enquanto literatura propriamente dita. Não será, então, um procedimento extraliterário procurar explicitar esta hipótese intrínseca a cada obra e verificar como esta a traz em sua forma. Também é possível confrontar a visão da obra com as hipóteses fornecidas pela antropologia e a sociologia enquanto ciências em si, assim verificando em que elas divergem, como as últimas podem nos ajudar a interpretar aspectos da primeira e mesmo em que esta poderia trazer elementos a serem acrescentados às ciências ou levá-las a rever algum de seus pontos.

É este o procedimento que será adotado nesta pesquisa, mais especificamente aplicado à temática sacrificial na literatura. Para isso é preciso definir de partida uma dada visão antropológica e sociológica entre outras sobre a qual se basear. Procurarei esclarecer agora qual é a que escolhi e julgo adequada para o estudo das questões a que tentarei responder.

\section{2- Concepção antropológica}

\section{1 - Mimetismo e gênese da cultura}

A principal referência teórica para esta pesquisa será a teoria mimética, desenvolvida por René Girard. Não obstante, procurarei articular esta teoria com outras linhas, as quais, acredito, podem completar algumas de suas insuficiências, além disso, procurando desenvolver por conta própria alguns elementos já levantados por Girard e outros autores girandianos.

A hipótese mimética é sabidamente ambiciosa, propondo uma explicação unitária para a cultura, desde o processo de hominização (a passagem dos grupos hominídeos

pré-humanos para o estado de cultura), passando pela estruturação de todas as culturas, as relações entre indivíduos, a crise contemporânea e, mesmo, prevendo um fim do mundo para um futuro mais ou menos próximo. O eixo central que permite a articulação de toda esta teoria é o conceito de mimetismo, cuja atuação procuraremos acompanhar passo a passo. 
Para Girard, o mimetismo é uma tendência que os hominídeos dos quais evoluiu a humanidade compartilhavam já com os animais. Ele tem bases biológicas e neurológicas, e leva os indivíduos a copiarem as ações com que se deparam.

Uma das principais manifestações do mimetismo é a mímesis de apropriação: a tendência dos indivíduos a, ao notaram que um outro pretende se apropriar de dado objeto (alimento, por exemplo), procurarem também se apropriar deste objeto, o que leva a um conflito por sua posse. Nas outras espécies, tais conflitos são contidos por mecanismos que os impedem de ter consequências demasiado violentas, entretanto, entre os antepassados da humanidade a violência recíproca pouco a pouco passou a ir além destas barreiras, podendo chegar ao extremo.

Ainda pela ação do mimetismo, a violência recíproca entre dois indivíduos era copiada pelos demais membros de seu grupo, deste modo a violência mimética contagiando toda a coletividade, a qual, no limite, poderia sucumbir a esta violência interna. Porém, ao mimeticamente adotarem como objeto de sua agressividade o objeto da agressividade dos outros, esta tende a convergir sobre um indivíduo único, o qual, sem maiores defesas, será expulso ou morto pela coletividade em conjunto. Uma vez eliminado aquele que se tornou o alvo de toda a violência do grupo, esta se desfaz por se ver privada de objeto e assim a paz regressa ao grupo.

A todo este processo Girard chama mecanismo de bode expiatório, ou mecanismo sacrificial. Para ele, tal acontecimento é tão impressionante para os membros da coletividade que o vivencia que a partir dele se desenvolve toda a cultura. Em alguns momentos de sua obra, isto pareceria se dar de modo excessivamente brusco, mas em outros momentos ele chega a esclarecer que seria com a repetição deste ciclo durante um longo processo de evolução que aos poucos se formariam as culturas.

Os membros de um grupo não podem interpretar um fenômeno que parece exceder tão grandemente seus poderes como tendo sua origem neles próprios, vendo assim, tanto a violência que deles se apodera como a súbita paz que a sucede como provenientes de forças autônomas exteriores à comunidade. Com uma consciência parcial dos verdadeiros mecanismos por trás da crise mimética, a comunidade cria regras e tabus que visam prevenir as rivalidades internas capazes de desencadear o 
contágio mimético e a escalada da violência. Por exemplo, a vingança contra um ato de violência sendo rigidamente regulada de modo ritual e o acesso aos objetos de desejo mais propícios a incitar rivalidades violentas, como parceiros sexuais, estando sob prescrições igualmente rígidas. Por outro lado, criando ritos nos quais procuram reproduzir os acontecimentos da crise espontânea em sua origem, para assim repetirem também os seus efeitos de purga da violência e pacificação. Nos rituais, os tabus e distinções da comunidade são quebrados e uma vítima substitutiva, primeiro humana e mais tarde animal ou mesmo representada por um objeto, é sacrificada, representando a vítima original.

É à violência substancializada, vista como autônoma e situada espacialmente do lado de fora dos limites da comunidade que corresponde o conceito de sagrado ou seus correspondentes nas diversas culturas. É uma força impessoal e ambivalente, com uma face negativa ligada à violência nefasta da crise, e uma face positiva, ligada a seus efeitos de reestabelecimento da paz e de reunião da comunidade, fornecendo seus valores culturais. Todos os ritos visariam manipular esta perigosa substância sobrenatural de modo controlado, permitindo que ela atue na comunidade na medida correta para vivificá-la, mas não ao ponto de se apoderar dela e lançá-la em nova crise.

As divindades míticas são a transfiguração da vítima original. Na visão mítica, esta vítima é vista como sobrenaturalmente ligada ao sagrado por ser ela, como já dito, tanto quem traz a crise quanto quem a desfaz e reestabelece a paz, desse modo sendo, como o sagrado em si, ambivalente. A ênfase de cada culto pode estar no sagrado impessoal ou na divindade, neste caso sendo ela a reger o sistema de culto sacrificial, mas para Girard, trata-se sempre da reprodução da crise fundadora, visando que a violência que se identifica com o sagrado recrudesça, para então expulsá-la no sacrifício, permitindo a manutenção do sistema cultural.

Para Girard, são estes os princípios que, com base na natureza mesmo biológica do ser humano, regem a passagem à cultura e estruturam todas as sociedades humanas. Os princípios do mimetismo, porém, continuam a atuar no contexto cultural sob formas próprias a ele, sendo estas, na realidade, o foco do interesse de Girard. Eles mantêm e mesmo ampliam tanto seu potencial construtivo quanto destrutivo, os 
mecanismos culturais criados para manter o primeiro e conter o segundo não bastando para impedir novas rivalidades e novas crises não rituais, as quais podem eventualmente resultar na refundação da ordem cultural sob formas alteradas, mas em que a dinâmica do mimetismo e dos mecanismos sacrificiais sempre persistem, mais ou menos visíveis.

Antes de estudar as especificidades do mimetismo já inserido na cultura, acredito necessário discutir um elemento desta última, a que Girard dá pouco peso: a esfera simbólica, discursiva e axiológica. Poderemos fazê-lo empregando os conceitos relacionados à reflexão sobre o éthos, deste modo pensando a ética.

Esse procedimento nos permitirá acompanhar com um pouco mais de clareza como o processo de hominização descrito por Girard se dá gradualmente, acompanhando o processo de evolução humana. Além disso, Girard tende, principalmente em suas primeiras obras, a negar explicitamente as diferenças entre os diversos sistemas culturais, afirmando que o essencial em todos é a continuidade dos sistemas de bode expiatório e sua ocultação, que a multiplicidade de formas apenas torna mais difícil reconhecer. Também isso poderá ser matizado ao se atentar às especificidades dos sistemas de valores subjacentes às diversas sociedades ou a correntes de discurso em seu seio.

\section{2 - Éthos}

Como se sabe, a percepção do mundo pelos seres humanos não é direta. Não apreendemos os objetos puramente em sua materialidade, mas inevitavelmente interpretamos aquilo com que nos deparamos segundo uma visão de conjunto significativa.

Para efetuar essa interpretação constante do que o rodeia, é preciso que o indivíduo esteja dotado de um sistema simbólico que lhe permita reagir afetivamente a objetos e eventos, Ihes conferir sentido e atuar frente a eles segundo certos padrões. Cada um adquirirá este sistema por sua inserção na cultura a que pertence e que o precede. 
À medida que o recém-nascido se desenvolve, ele segue os modelos à sua volta e, por meio de uma combinação de mimetismo direto e instrução direcionada em proporções variáveis de cultura para cultura, se apropria da maneira de agir, pensar e valorar própria à sua sociedade ou ao segmento dela em que se insere. É a estes padrões de comportamento socialmente herdados que se chama éthos, e esse não determina apenas o modo de agir de um indivíduo, mas sua própria subjetividade.

Pensando de um ponto de vista filogenético, podemos supor que o desenvolvimento da capacidade simbólica e natural do ser humano se deu gradativamente, acompanhando sua evolução biológica, acelerando-se e passando a se determinar pela dinâmica interna a partir do momento em que se acumulou suficiente material cultural. $^{3}$ Unindo tal visão com a hipótese de Girard, é plausível supor que os elementos de um fenômeno tão marcante como seria a crise mimética para uma comunidade de hominídeos em processo de passagem à cultura foram aos poucos se recobrindo de uma significação simbólica, assim como os demais acontecimentos recorrentes que afetam o grupo. Por exemplo, a atitude instintiva de evitar um objeto que houvesse sido causa de conflitos violentos aos poucos receberia uma interpretação que se transmitiria a todos os membros de uma comunidade e se consolidaria em um tabu; do mesmo modo, talvez a visão inquietante da vítima morta pelo grupo aos poucos se convertesse na interpretação de sua sobrevivência em um plano além do imediatamente visível e fosse retrospectivamente ligada à crise que a precedia em uma narrativa mítica que se transmitiria e desenvolveria ao longo do tempo, a partir daí os eventos da crise podendo ser interpretados e repetidos ritualmente à sua luz. É deste ponto em diante que poderíamos considerar constituída uma cultura e seu éthos, visto os tabus e a instituição do ritual já serem o bastante para determinar socialmente as ações dos indivíduos.

Pelo mesmo processo de interpretação e atribuição gradativa de significado passariam paralelamente fenômenos como o ciclo das estações; o ciclo vegetal; o nascimento, crescimento, envelhecimento e morte; ameaças naturais; e o desenvolvimento de técnicas e instrumentos rudimentares. Esses últimos fenômenos, contudo, não possuem a mesma capacidade de estruturação da cultura que o sacrifício

\footnotetext{
${ }^{3}$ Ver Geertz Clifford. A interpretação das culturas. São Paulo: Gen/LTC, 2018.
} 
dentro da visão aqui assumida, pelo que podemos ver nele o eixo que unifica as interpretações que constituem os demais temas míticos à medida que, aos poucos, se entrelaçam e constituem uma visão de mundo organizada. Não obstante, tais temas têm enorme influência psíquica e prática na vida de um grupo humano, o interesse que recebem se justificando por eles mesmos.

A visão de mundo e a prática social de uma comunidade inevitavelmente comportarão valores, ainda que implícitos, que os orientarão. Se nas comunidades tribais primitivas, assim como em muitas comunidades tradicionais dos dias atuais, 0 éthos seria bastante unitário, não havendo grande espaço para variações e divergências internas, em diversas culturas ele aos poucos se complexifica, seja pelo surgimento de visões diversas, interesses conflitantes, pela influência de outros sistemas culturais ou outras razões. Assim, o indivíduo que se desenvolve em uma sociedade de tendências diferenciadas terá que optar entre elas - faça-o com maior ou menor clareza - e para tanto deverá refletir sobre os projetos e valores divergentes que comportam - novamente com maior ou menor consciência - e eventualmente propor outros. Tal discernimento é a reflexão ética.

Mas é preciso destacar que tal escolha entre tendências e valores não se dá nunca de forma pura. Cada indivíduo é afetado pelos discursos diversos a que é exposto, o mais das vezes professando valores conflitantes entre si; orientando-se ora por dado sistema valorativo, ora por outro; assumindo explicitamente certos valores e não se comportando de acordo ou procurando realizá-los por meios inadequados.

Isso, a que poderíamos chamar "incoerências", certamente se deve a fatores diversos, tais como a justificativa ideológica de interesses econômicos, motivações psicológicas inconscientes, as dificuldades concretas para a realização de ideais abstratos e mesmo o fato de que não necessariamente a coerência maximamente rigorosa seja desejável, a realidade exigindo a revisão de valores. Mas além de todas essas razões, talvez não tenha menor peso o fator mimético.

A dinâmica do mimetismo e os mecanismos sacrificiais continuam a atuar no âmbito da cultura, porém recobertos por interpretações simbólicas e conceituais que as afetam e são por elas afetadas. 
Passaremos agora a examinar seu funcionamento na cultura, segundo a teoria girardiana, procurando articulá-lo com os elementos éticos e axiológicos aqui apresentados, os quais Girard não nega, mas aos quais dá pouco destaque, ao menos em sua formulação teórica.

\section{3 - A dinâmica do desejo mimético}

\section{1 - Mediação externa e constituição da subjetividade}

A principal forma que assume o mimetismo no âmbito humano propriamente dito é o desejo mimético. Não é o mero impulso imitativo que nos leva a desejar um objeto, como na mímesis de apropriação, tampouco o valor intrínseco a ele e muito menos a espontaneidade do desejo nascido no íntimo de um indivíduo.

Para Girard, como para muitos outros pensadores, todo indivíduo sente-se insatisfeito e carente de uma plenitude de ser. Cada um acredita ser o único a sofrer desta condição e vê aos outros como possuidores da plenitude, procurando também alcançá-la. Para isso tentará imitá-los em tudo e assim desejará os objetos que acredita desejados pelo outro, crendo serem eles a possuírem a virtude de conferir a plenitude almejada. Esta é a mediação mimética, aquele de quem se copia o desejo sendo chamado por Girard modelo mimético ou mediador do desejo, e quem o toma por modelo, discípulo.

Caso a mediação não conduza à rivalidade pela posse do objeto, ela é chamada mediação externa, por oposição à mediação interna, aquela que a suscita. Esta mediação mimética não conflitiva pode ocorrer seja por haver um sistema de diferenciação social em que o papel do modelo e do discípulo estejam preestabelecidos com suficiente autoridade para impedir sua disputa, seja por o modelo se situar a uma distância social excessivamente grande com relação a seu discípulo (como um chefe político carismático para um cidadão comum), seja por se situar em um passado histórico, mítico ou plano ficcional, como no caso de um herói nacional, um personagem mítico ou mesmo literário, os quais podem servir de modelo para o desejo e o comportamento de alguém da mesma maneira que um outro fisicamente presente. 
É pela mediação externa menos diretamente ligada a um modelo exclusivo e mais a influências cumulativas, e muitas vezes contraditórias, dos diversos modelos à sua volta que, desde a infância, um indivíduo assimila as práticas sociais básicas de sua cultura, elementos das correntes de discurso que circulam em sua sociedade, bem como os valores implícitos ou explícitos que orientam sua forma de agir.

Todos esses elementos são internalizáveis e podem atuar mesmo na ausência da mediação de um modelo direto, de modo que poderíamos considerá-los parte do que compõe o inconsciente, juntamente com pulsões instintivas, traumas e o que mais possa influir autonomamente na vida psíquica e no comportamento de um indivíduo. São eles que impulsionam o comportamento geral de alguém, mas não se deve considerar esta motivação internalizada de modo estanque, pois ela sempre interage com os elementos externos, a atuação social em instituições diversas, frente a transformações históricas e na interação com outros indivíduos. Neste processo, além dos limites práticos que se impõem às determinações daquilo já incorporado pelo indivíduo, o mimetismo continua agindo e a interação com os novos modelos, pessoais ou coletivos, com que se depara, tanto influirá em sua ação mais imediata - por exemplo, na adesão temporária a uma moda, na adoção passageira do discurso de um interlocutor ou na incorporação a um movimento de massa -, quanto fornecerá novo material a ser internalizado, mais ou menos profundamente, e continuar a agir nesta dinâmica.

Nesse processo formam-se padrões de desejo e comportamento que se manifestam alternadamente na ação de um indivíduo. Podemos considerar que a eles subjaz sempre uma estrutura valorativa, a qual pode ser depreendida pelas práticas que os constituem e aquilo que buscam realizar ou obter. Muitas vezes, tais padrões são acompanhados por um discurso, mais ou menos coerente, que os deveria justificar, o qual pode ou não estar de acordo com a estrutura valorativa efetivamente correspondente a eles ${ }^{4}$.

\footnotetext{
${ }^{4}$ Nesta questão utilizo-me das reflexões de Juan Luís Segundo acerca de fé e ideologia em 0 homem de hoje diante de Jesus de Nazaré. São Paulo: Edições Paulinas, 1985. Retomaremos esses conceitos no terceiro capítulo.
} 
Podemos falar de tais padrões de comportamento tanto com relação a atitudes concretas pontuais quanto a padrões mais amplos nos quais estas se inserem. As estruturas valorativas destes últimos muitas vezes correspondem a modelos de comportamento social tais como o individualismo, nacionalismo, autoritarismo baseado na propriedade de terras, tradicionalismo, altruísmo, ascetismo, para tomar exemplos de tipos diversos sem dividi-los mais criteriosamente. Elas convivem em um mesmo indivíduo, interagindo de modo complexo e formando como níveis de valores mais ou menos profundamente arraigados, os quais podem ser artificialmente isolados para fins de análise.

No caso de estruturas valorativas mais passivas, como o individualismo desinteressado ou certos gêneros de submissão à autoridade, não há a necessidade de modelos miméticos muito específicos, elas sendo assumidas basicamente através da mediação de inúmeros modelos que lhes são socialmente oferecidos, sem necessariamente um peso particularmente decisivo. Entretanto, estruturas valorativas amplas podem ser assumidas de modo mais ativo, o indivíduo buscando se conformar conscientemente às atitudes e ações que ditam, caso em que a procura por modelos concretos, mais ou menos exclusivos, pode ser intencional ou, ao menos, sua presença será claramente perceptível. Além de indivíduos de suas relações pessoais que veiculem esses valores, modelos como estes podem ser buscados em livros ou outros produtos discursivos explicitamente ligados aos valores em questão; em relações propriamente de mestre e discípulo; ou em figuras públicas que os representem, como ícones políticos ou religiosos do presente ou do passado.

Ao menos em uma sociedade complexa, mesmo para os que assumirem uma estrutura valorativa com maior consciência, esta não será absoluta. A exposição a modelos e discursos paralelos não pode deixar de fazer com que outros níveis de valores se formem no indivíduo e exerçam ao menos uma influência secundária ou eventual sobre suas ideias e atos. A emergência de um destes níveis secundários ou mesmo a troca definitiva ou temporária do nível predominante dependerá, muitas vezes, da influência direta de um modelo mimético. 
Além disso, em toda sociedade haverá certas estruturas valorativas predominantes, ligadas a seu éthos, das quais dificilmente se poderá escapar inteiramente, mesmo quando se tenha a intenção de fazê-lo, e que formam como um nível básico de valores. Por exemplo, em nossa sociedade globalizada, em graus muito diferentes segundo uma enorme série de fatores variáveis, dificilmente alguém estará completamente livre de certo apelo do que eu chamaria individualismo eletivo, por um lado, e de certos princípios éticos de matriz cristã, ainda que se rejeite a um ou ambos direta e virulentamente.

Até aqui, estivemos abordando como o mimetismo atua na constituição da subjetividade do indivíduo de modo que ele possa agir, até certo ponto, por si mesmo, sem a determinação direta de uma relação mimética. Isto não significa de maneira alguma um retorno à ilusão de autonomia do indivíduo e espontaneidade do desejo que Girard ataca duramente sob o nome de "mentira romântica", mas apenas de ressaltar como a própria constituição daquilo que no indivíduo é autônomo se dá pelo mimetismo.

Essa esfera relativamente autônoma não é negada pelo criador da teoria mimética, mas recebe pouca atenção pelo fato de ele se interessar principalmente pelos casos em que a dependência direta do modelo é mais impositiva. Daremos, agora, um pouco mais de atenção a esses casos, embora procurando manter em mente como também estas relações miméticas são influenciadas por aquilo que já se consolidou previamente como parte da subjetividade do indivíduo apanhado na mediação interna conflitiva.

Antes de passar às análises, pode valer a pena sugerir, apenas, que é a interação dessas esferas relativamente autônomas com a influência direta de modelos miméticos que, em grande medida, determina o maior ou menor grau de submissão de um indivíduo ao mimetismo de mediação interna. Elas também seriam parte importante do que permitiria a libertação parcial do mimetismo destrutivo, a que Girard chama "conversão", pelo ganho de consciência - a que eu consideraria, em geral, mais intuitiva do que faz o autor - da dinâmica do desejo mimético e eventual adoção consciente de um modelo não conflitivo, o qual, para Girard, é por excelência o 
Cristo, embora não necessariamente. Isto se daria em um processo excessivamente complexo para que as condições que levam a um ou outro resultado sejam previsíveis, mas que talvez seja passível de reconstituição parcial pela análise caso a caso.

\subsection{Mediação interna}

Se a mediação externa é aquela em que, por razões diversas, o indivíduo não rivaliza com seu modelo mimético, a mediação interna é aquela em que se dá a mediação dupla, ou seja, em que aquele que serve de modelo para o desejo do outro o toma, por sua vez, como modelo.

Apesar de falarmos em modelo e discípulo, estas posições são, na verdade, complementares e alternativas, pois também aquele que para o outro aparece como autossuficiente e pleno está sujeito à mesma carência de ser que ele próprio, e apenas pode desejar mimeticamente. Não sendo em alguma qualidade própria ao objeto que reside o valor que este parece possuir através da mediação mimética, a sua posse não pode satisfazer e ele parecerá ter perdido suas virtudes a menos que o desejo de outro, o discípulo, o confirme como digno de ser desejado.

A partir do momento em que aquilo que se possui é desejado pelo outro, porém, passa-se a temer perdê-lo para ele, sendo preciso rechaçar o rival. Deste modo, o mediador será um modelo obstáculo para o discípulo; ao mesmo tempo o que suscita seu desejo e barra a sua satisfação.

Ao se ver incapaz de superar o obstáculo constituído pelo modelo, o discípulo toma isso como uma confirmação de sua superioridade, a qual aumentará o seu prestígio, bem como da própria inferioridade e carência. Entretanto, de acordo com o que precede, é apenas a seus olhos que o outro ocupa tal posição, já que sua suposta posse do objeto e da plenitude de ser que esta concede nunca se concretiza, ou estando ameaçada pela rivalidade do discípulo (para ele modelo) ou perdendo qualquer valor na sua ausência. Desse modo, os indivíduos mais inteiramente dependentes dessa dinâmica buscarão sempre estar diante de um modelo obstáculo, seja ao abandonar um objeto de desejo tão logo sua posse pareça garantida, passando 
a desejar outro cuja posse esteja barrada por um rival, seja procurando fazê-lo desejar por um outro que a ameace.

Os indivíduos presos na mediação dupla competirão pela posse do objeto que um designa ao outro como possuidor de valor, neste processo tornando-se cada vez mais semelhantes, já que cada ação que um dos dois praticar buscando a vitória na disputa será reciprocamente praticada pelo outro, que busca o mesmo fim. Cada um acusará o outro de ser o iniciador da disputa e se acreditará justificado em sua própria violência por considerá-la como reação frente à do outro. De fato, visto o papel secundário que tem o objeto na disputa, esta tende a se desligar dele e se autonomizar. O que cada um busca é vencer o adversário.

Os indivíduos que chegaram a este ponto são chamados por Girard de irmãos inimigos ou duplos miméticos. Assim como na crise fundadora, a rivalidade dos duplos tende a envolver aqueles a seu redor e, caso ainda se trate de uma comunidade com dimensões reduzidas o bastante, pode atingir a ela toda, fazendo com que todos se tornem duplos miméticos indiferenciados.

Os sistemas de diferenciação cultural visam justamente evitar este retorno da crise mimética, mas quando, por razões diversas, não bastam para garanti-lo, eles sucumbem à indiferenciação mimética e mais uma vez será preciso que a violência da comunidade se concentre em uma vítima única para que a ordem retorne.

Dependendo do quão bem o sistema cultural ainda seja capaz de cumprir suas funções, a nova crise e o mecanismo sacrificial poderão reestabelecer a ordem em seu seio, mantendo sua vigência e iniciando um novo ciclo sacrificial que culminará em nova crise e novo sacrifício. Se a capacidade de contenção da violência intestina estiver enfraquecida, os ciclos se sucederão cada vez mais rapidamente e seu poder pacificador será menor, até que surjam condições para dar origem a um novo mito e novas estruturas culturais de maior eficiência para o novo contexto.

Em sociedades maiores e mais complexas, a crise mimética continua existindo, mas será, evidentemente, cada vez mais difícil que ela envolva diretamente a cada indivíduo em um impulso de violência mimética indiferenciada, bem como a 
unanimidade completa se tornará mais distante. Nestas sociedades, quando se trata de crises que as afetem realmente como um todo, é principalmente entre as instituições e partidos que as compõem - e que por sua vez se estruturam, em grande medida, pelo mimetismo e o sacrificialismo em seu interior -, que se dão os conflitos e se reestabelecem as novas unanimidades relativas. Nelas, acredito, por mais amplos que sejam seus efeitos pacificadores, cada sacrifício provoca de imediato novas oposições, que em alguma medida devem ser contidos pela coerção direta.

Muitas vezes, também, os bodes expiatórios se tornam coletivos, havendo dados grupos no interior de uma sociedade contra os quais se pratica uma perseguição constante, por vezes visando seu total extermínio. Ainda assim, casos em que o sacrifício, sob uma forma ou outra, de bodes expiatórios individuais tem grande efeito sobre a sociedade como um todo continuam a existir, em geral sendo necessário que as vítimas de tais sacrifícios sejam figuras particularmente influentes na sociedade.

\section{4- Idolatria}

Além do sacrifício ritualizado ou institucionalizado e das repetições mais espontâneas das crises sacrificiais, há ainda outra forma de sacrifício cujas especificidades gostaria de acrescentar a estas estudadas por Girard, a qual, na verdade, em geral se mescla a elas. É o sacrifício idolátrico.

O ídolo, no sentido que o emprego, é tudo aquilo que um indivíduo ou comunidade erige, com maior ou menor consciência, como seu valor absoluto, em seu nome considerando necessária a morte de seres humanos.

O próprio ídolo é mimeticamente constituído, pois é necessária a sua aceitação coletiva por um grupo, o reconhecimento dele por cada um como valor e critério últimos, servindo de modelo para os demais. Na verdade, podemos mesmo considerar que sua primeira aparição se dá com o surgimento da cultura, que toma suas próprias regras e instituições como ídolos, apoiados no sagrado, e é, de modo mais ou menos claro, em seu nome que se praticam os sacrifícios rituais. 
De modo mais específico, alguns dos ídolos mais poderosos, que podem se colocar como guia absoluto para a conduta de vastos grupos humanos, são: a monarquia; o Império; a adesão a uma forma específica de crença religiosa; a pátria ou a nação; a economia; o mercado ou a ideia de revolução. Todos estes são tomados por aqueles que os idolatram como justificativa para a guerra contra outros povos e sua conquista; para a escravidão ou a exploração extremada de grandes parcelas de suas sociedades; e mesmo para o autossacrifício dos que o aceitam. Todos esses sacrifícios possuem papel similar ao do sacrifício girardiano, pois sua aceitação coletiva é um dos principais elementos de união no interior de uma comunidade.

\section{5- Cristianismo}

Um último ponto que, mesmo sem ser diretamente abordado nas análises que se seguem, deve ser apresentado nesta introdução por sua importância no pensamento de Girard é sua visão do cristianismo. Para ele, a religião cristã é essencialmente antissacrificial. Não apenas Jesus toma constantemente o partido dos bodes expiatórios de sua comunidade, como, embora as narrativas de sua morte apresentem grande semelhança com a estrutura sacrificial típica dos mitos em geral, ao invés de aceitar sua validade e apresentar o mecanismo como proveniente da esfera sobrenatural, elas revelam sua dinâmica e apresentam sua violência como imanente e proveniente da comunidade humana. Esta revelação representa um grande golpe contra o mecanismo sacrificial, pois para seu bom funcionamento é indispensável que a comunidade se mantenha inconsciente de sua verdade, do contrário não poderia se deixar levar pela violência mimética ao sacrifício do bode expiatório a que não poderiam ver como o responsável pela crise.

Também em outras culturas há linhas de pensamento antissacrificiais, por exemplo no budismo, em que há um famoso discurso do Buda contra o sacrifício ritual, além de seus princípios se oporem ao sacrifício em sentido mais amplo. Entretanto, não há qualquer tradição em que o antissacrificialismo é tão central quanto no cristianismo, ressaltando a identificação de sua divindade sacrificada com todas as vítimas. 
Isso não significa, absolutamente, que o cristianismo teria posto fim à vigência do sacrificialismo. Ironicamente, além de o próprio cristianismo ter recebido interpretações sacrificiais - predominantes, aliás - que permitem seu uso como o de qualquer mitologia para justificar as formas específicas de sacrificialismo das culturas cristãs, o próprio comprometimento da eficiência pacificadora do mecanismo sacrificial provoca um crescimento da violência e faz com que ele exija cada vez um maior número de vítimas para cumprir sua função, como seria o caso no nazismo ou no stalinismo.

Ainda assim, Girard acredita que o cristianismo lançou uma semente decisiva na cultura ocidental. Ele tornou cada vez mais difícil a unanimidade sacrificial e permitiu um crescimento gradual do reconhecimento dos bodes expiatórios enquanto tais, bem como da tomada de posição a seu favor. 


\section{1- O herói sacrificial épico}

\section{Surgimento do mito do herói}

O objetivo desta pesquisa é estabelecer aquilo a que podemos chamar "sacrifício" na literatura, sua correspondência a fenômenos sociais extraliterários e os caminhos pelos quais essa temática chega à literatura. Para isso, será preciso definir primeiramente o que aqui se entende por sacrifício.

Mais propriamente, o sacrifício é uma prática ritual, ligada ao culto de antepassados, heróis míticos, divindades ou mesmo potências sobrenaturais impessoais. Este sentido propriamente religioso é muitas vezes representado na literatura, mas não é o que nos interessa mais diretamente nesta pesquisa, ainda que seu tratamento ficcional muitas vezes se associe com o que será aqui o foco de nossa atenção. É, antes, o mecanismo recorrente que, para Girard, dá origem a este sacrifício ritual e continua a atuar espontaneamente após seu estabelecimento: a perseguição coletiva de um indivíduo único ou pequeno grupo no contexto de uma crise mimética; o mecanismo de bode expiatório, já abordado na introdução a este trabalho.

Além disto, procuraremos associar este sentido do sacrifício a outros que não correspondem diretamente ao mecanismo estudado por Girard, mas que possuem ligações com ele, a alguns dos quais, por vezes, o próprio autor aplica o termo, embora sem colocar com clareza suas especificidades; trataremos deles mais à frente. Não obstante, a representação dos fenômenos sacrificiais na literatura raramente corresponde de modo evidente à sua descrição teórica, isso tanto pelo fato de as ocorrências reais do mesmo assumirem formas bastante diversas, segundo os variados contextos em que se dão, quanto pelo fato de que a visão deles subjacente a cada obra terá suas características próprias, para começar, dificilmente sendo interpretados como "sacrificiais".

Três caminhos principais pelos quais os elementos sacrificiais podem vir a se fazer presentes na literatura seriam: a influência da tradição literária e a reprodução de elementos sacrificiais já presentes nela, no limite remontando aos mitos; a adesão do autor às tendências sacrificiais próprias a seu tempo, por exemplo ao assumir os bodes expiatórios de sua comunidade, representando-os como culpados e 
merecedores de punição; e a representação crítica do sacrificialismo, ainda que não entendido enquanto tal. Eles não são excludentes e muitas vezes se conjugam, sendo, por exemplo, comum que um autor, ao produzir uma obra de acordo com os cânones tradicionais a um só tempo dê vazão a suas tendências sacrificiais ou, mais raramente, lance um questionamento ético sobre os traços sacrificiais que aqueles contêm; do mesmo modo, sobretudo a partir do romantismo, uma mesma obra pode trazer uma forte crítica a tendências sacrificiais vigentes na sociedade e fundar sobre ela tendências persecutórias contra novos bodes expiatórios.

Quanto à transmissão de elementos sacrificiais pela tradição, primeiro mítica, então literária, isso se relaciona com a origem que o mito tem na transfiguração do mecanismo de bode expiatório. Para Girard, os mitos de uma comunidade representam de modo transfigurado ocorrências concretas desse mecanismo sacrificial que se deram em sua origem, por isso sendo sempre possível encontrar neles os elementos básicos que compõem a crise sacrificial (os estereótipos vitimários, como os chama Girard em 0 bode expiatório ${ }^{5}$ ), mais ou menos claros conforme a versão de um mito se distancia mais ou menos de sua representação original.

O mito tem como uma de suas principais características a tendência a ocultar a responsabilidade da comunidade por sua violência, não por má fé, mas pelo fato de que essa é acertadamente percebida como algo que ultrapassa as forças e a vontade de seus membros, apoderando-se deles pelo contágio mimético. Por isso, como indicado anteriormente, ela é vista como uma força autônoma, responsável tanto pela crise, quanto pela sustentação da ordem que esta vem desfazer e se reestabelece após o sacrifício: o sagrado. A essa força ambivalente se liga a vítima única do sacrifício, que por isso é divinizada e se torna uma divindade ou herói mítico, portadora tanto das características negativas como das positivas ligadas às duas faces do sagrado, já que o fim da crise com sua morte demonstraria ser ela a provocá-la e controlá-la, sendo deste modo que todo o acontecimento será representado no mito.

À medida que a comunidade perde de vista o acontecimento real por trás do mito, os indícios que apontam para ele passam a ser vistos como menos essenciais e

\footnotetext{
${ }^{5}$ GIRARD, René. 0 bode expiatório. São Paulo: Paulus, 2004.
} 
mesmo vergonhosos, sofrendo novos deslocamentos, tendendo principalmente a tornar a violência coletiva menos visível, assim como a separar os elementos negativos e positivos do sagrado, resultando em deuses e heróis cada vez mais puramente sublimes, de um lado, e de outro em vilões, monstros e demônios cada vez mais inteiramente baixos e malignos. Para Girard, é essa a razão pela qual em muitos mitos não estão presentes todos os estereótipos vitimários, que, entretanto, nunca são inteiramente apagados, o que permitiria, de certo modo, retraçar os passos do ocultamento mitológico pelo qual passou dado mito até a verdade do assassinato fundador que esconde.

Embora esse processo de alteração gradual do mito seja uma teoria sólida e útil, não parece plausível que todo mito tenha origem direta em um fenômeno sacrificial como os descritos pelo antropólogo francês. Seria, antes, o papel determinante da tradição mítica na constituição do imaginário de qualquer grupo humano que faz com que haja sempre uma forte mentalidade sacrificial, a qual poderá dar origem a novos mitos que portarão elementos sacrificiais ligados à crise sem necessariamente provirem de uma de suas ocorrências concretas. Um modo pelo qual isso pode se dar é a aplicação do imaginário sacrificial a outros eventos que não a crise mimética - o próprio Girard fala em A violência e o sagrado $^{6}$ da interpretação sacrificial de mortes naturais ou acidentais em certos grupos tribais -, de que um exemplo interessante é a mitologização da morte em batalha do guerreiro carolíngio Rolando, cujo aproveitamento literário em breve analisaremos em La chanson de Roland ${ }^{7}$.

Outra possibilidade, ainda, é a atuação do imaginário sacrificial no surgimento de uma narrativa sem referência a eventos factuais. Disso podemos encontrar interessantes exemplos, citados por Marie Luise von Franz em seu livro A interpretação dos contos de $\mathrm{fada}^{8}$, um dos quais recente o bastante para ter sido documentado. O mais seguramente registrado diz respeito a um ritual que começou a ser praticado por um grupo indígena da América do Norte, seu ponto de partida tendo

\footnotetext{
${ }^{6}$ GIRARD, René. A violência e o sagrado. Rio de Janeiro/São Paulo: Paz e Terra, 1998.

| ${ }^{7}$ ANÔNIMO, La chanson de Roland, tradução para o francês moderno por FABRE, Joseph http://www.litteratureaudio.com/livre-audio-gratuit-mp3/anonyme-la-chanson-de-roland.html

${ }^{8}$ FRANZ, Marie Luise von. A interpretação dos contos de fada. São Paulo: Paulus, 1990.
} 
sido o sonho de um jovem, no qual um xamã recebeu instruções dos espíritos para a comunidade. O outro é o festival da águia, dos esquimós, cujo surgimento não é registrado, mas, a partir do mito de sua origem e em comparação com o primeiro exemplo, permite a von Franz levantar uma plausível hipótese a esse respeito. O mito narra que, certa vez, uma bela águia foi abatida por um caçador, que a empalhou e passou a fazer-lhe oferendas de alimento. Algum tempo depois, o mesmo homem perdeu-se em uma tempestade de neve, sendo guiado por dois espíritos águia em forma humana até uma cidade, onde a mãe da águia abatida, cujo coração bate lamentosamente em luto pelo filho, o agradece pelo bom tratamento que dispensa a esse, dando-Ihe, em retribuição, as instruções para a prática do festival. Para a intérprete junguiana, o encontro com os espíritos teria sido um sonho tido pelo homem ao desmaiar em meio à tempestade, no qual seu inconsciente fornecia uma narrativa que dava significado à sua experiência prévia com a ave que matara e que the impressionara. Nesta sociedade, em que sonhos e visões eram considerados comunicações com o sobrenatural, a experiência do homem foi adotada pela comunidade como um mito (ainda que pouco desenvolvido), no qual podemos ver traços de um sacrifício da águia, embora sem indícios da crise sacrificial.

Visto em sua origem a literatura surgir do mito, muitas vezes sendo difícil traçar o limite exato em que termina um e se inicia o outro, ela herda de sua tradição os elementos sacrificiais que, na visão girardiana, constituem sua base, mais ou menos perceptíveis. Particularmente na épica isto é verdadeiro, porém, as sociedades que a produzem, via de regra, pertencem a um estágio bastante avançado no processo de dissociação da face positiva e negativa do sagrado, optando por levá-lo ao limite. Além disso, pareceria mais provável que os mitos heroicos que lhes servem de base, mais frequentemente, não seriam o desenvolvimento direto da transfiguração mítica de um mecanismo sacrificial, mas o aproveitamento dos modelos míticos para a glorificação de lideranças, reis, guerreiros ou na criação de narrativas ligadas à legitimação de seu ethos. Por tudo isso, o caráter sacrificial do herói épico é bastante perceptível, mas nem sempre fácil de definir de acordo com a perspectiva girardiana.

A face maléfica do herói mítico mais próximo à transfiguração original do bode expiatório se faz visível em crimes e transgressões que cometeriam dos mais sagrados 
tabus, por exemplo ligados ao incesto, bem como na presença de características físicas, morais e sociais desprezíveis, como deformidades, origem estrangeira, velhice ou indigência. Essas últimas, a que Girard chama sinais vitimários, são todas características que predispõem as coletividades a tomarem um indivíduo como bode expiatório, enquanto as primeiras são as acusações lançadas sobre ele para justificar sua identificação como fonte da culpa que justificaria a crise enquanto punição divina.

De acordo com a tendência de dissociação do sagrado positivo e negativo, o herói épico normalmente é quase inteiramente desprovido de traços negativos. Em sua caracterização predomina grandemente aqueles ligados aos valores guerreiros aceitos socialmente como louváveis e o negativo sobrevive principalmente na forma de excessos desses valores, o quão nocivos ou culpáveis sendo bastante variável.

Passaremos agora a examinar essas questões em textos concretos.

\section{Deslocamentos sacrificiais em Gilgamesh}

Um exemplo em que os excessos do herói levam a coletividade a se voltar unanimemente contra ele, mas em que a violência coletiva está ausente, a punição de resto não particularmente severa - sendo delegada aos deuses, está presente na mais antiga obra literária conhecida: $\mathbf{O}$ épico de Gilgamesh ${ }^{9}$. Nele, o excesso de valor guerreiro do rei semidivino e sua excessiva virilidade o fazem entrar frequentemente em brigas com os jovens de sua cidade, bem como a ter com mulheres relações sexuais fora das regras sociais. Isso leva seus súditos a implorarem aos deuses que o façam moderar-se, pelo que estes criam o duplo do rei, Enkidu, que o iguala em força, fazendo-os lutar. Ao fim eles se convertem em grandes amigos, o herói se tornando menos desordeiro.

Embora também o personagem de Enkidu termine por se converter em um herói quase inteiramente desprovido de características negativas, podemos ver neste duplo de Gilgamesh o personagem que carrega os traços de sagrado maléfico de que o outro está desprovido. Ao ser criado, de início ele vive entre os animais selvagens, sendo como um deles, tal elemento de bestialidade condizendo com o caráter

\footnotetext{
${ }^{9}$ https://www.youtube.com/watch?v=C3A4qpoBkps
} 
monstruoso da vítima transfigurada, que porta traços da indiferenciação de algumas das distinções essenciais para a cultura, como aquelas entre mulheres e homens, animais e seres humanos.

Por fim, é Enkidu que representa um papel mais propriamente sacrificial, já que, após tornarem-se amigos, ele e Gilgamesh se lançam em aventuras típicas dos chamados heróis civilizatórios, matando o gigante Hunbaba e o touro celeste que a deusa Ishtar envia para se vingar do rei por tê-la rejeitado como esposa. Esses atos, embora louváveis, exigem punição divina ${ }^{10}$, que consistiria na morte de um dos dois, a qual recai sobre o outrora selvagem Enkidu. Assim, o duplo do rei torna-se propriamente uma vítima substitutiva, morrendo em seu lugar, não apenas sendo o único a pagar pelos crimes comuns a ambos, mas ainda mais ao levarmos em conta que o touro fora enviado para levar Gilgamesh à morte.

Ainda é interessante um segundo indício da crise sacrificial nesta obra, além das desordens causadas pelo rei e a reação de seus súditos. Esta segunda crise também seria advinda de seu comportamento excessivo e traria elementos mais claros da indiferenciação transfigurada que Girard vê como principal característica da crise, porém permanecendo apenas como uma ameaça. Refiro-me à ameaça da deusa Ishtar de, caso lhe recusassem o direito de enviar o touro contra o herói que a insultara, romper os portões do mundo dos mortos, fazendo com que as almas destes invadissem a terra, superando em número aos viventes.

A indiferenciação entre vivos e mortos é uma das mais temíveis nas sociedades em que a visão mítica é realmente forte, havendo culturas que interpretam qualquer conflito violento interno como um retorno dos antepassados, uma crise provocada pela invasão dos limites da comunidade pelo sagrado. Desse modo, podemos considerar que a planejada morte de Gilgamesh, que termina por se converter na

\footnotetext{
${ }^{10}$ Embora em nosso texto não haja referência a qualquer contaminação sobrenatural, este acúmulo de culpa na prática do ato em si meritório de eliminar monstros parece próximo da noção grega de contaminação pelo kratos. René Girard estuda este conceito em A violência e o sagrado, op. cit., considerando-o um dos exemplos de substancialização da violência no sagrado. O kratos seria a mesma força que permite aos heróis a prática de seus feitos meritórios na guerra ou ao combater monstros, mas os contamina e exige purificação ritual, do contrário conduzindo à sua ruina.
} 
morte de Enkidu, atua como o sacrifício que põe fim antecipadamente a uma crise de indiferenciação violenta no seio de sua comunidade.

Em tal deslocamento da culpa de Gilgamesh para Enkidu e sua subsequente morte punitiva podemos, talvez, ver uma tendência correspondente àquela de autonomização do poder político do rei guerreiro, desvinculando-se de seu papel ainda mais ligado ao mítico e ao ritual. Na Suméria, havia a prática do regicídio ritual cíclico, já não presente entre os babilônios, dos quais provém a versão que nos chegou da obra épica. Em muitas culturas essa prática foi substituída pelo sacrifício de um outro gênero de vítima, humana ou animal, que representaria o rei, permitindo assim que ele prosseguisse estabelecido em seu poder. Mesmo que a morte de Enkidu possa provir já da versão suméria, não parece impossível que ela reflita um impulso nesta direção.

Neste sentido, é interessante que a recusa da deusa pelo herói se deva ao mau destino que esta sempre reservou a seus consortes humanos - o que a tradição de análise mitológica normalmente associa exatamente ao regicídio ritual -, e que na obra é visto, incluso pela própria deusa, como culpável, ainda que ela se enfureça por ser recriminada por isso. Igualmente significativo é que o principal motivo explícito da obra seja o medo de Gilgamesh da morte, à qual tenta evitar, perpetuando-se no poder, tal como os reis sagrados ao transferirem o sacrifício a que deveriam se submeter a uma vítima substitutiva. Ao fim, a "moral" do mito é a aceitação da efemeridade da vida humana por oposição à dos deuses, mas a morte em questão sendo a morte natural ou em batalha condizente com os ideais imperiais, a qual deve ser aceita com dignidade e resignação em seu devido momento, não uma morte sacrificial ritual.

\section{Homero}

\subsection{Heróis homéricos}


Se no mito de Gilgamesh mesmo nos personagens em que a face negativa do sagrado se faz mais visível esta não é tão acentuada ${ }^{11}$, isto se dá de modo bastante diferente na tradição grega, que nos interessa mais de perto por sua influência essencial na tradição ocidental. Na llíada ${ }^{12}$ e na Odisseia $^{13}$, sobretudo na primeira, os heróis são ainda mais sublimados que Gilgamesh. Nos poucos dias do sítio de Troia narrados pela musa homérica, quase nada dos muitos elementos sacrificiais ligados às tradições de seu mito aparece, os heróis às portas da cidade nos sendo apresentados com pouco mais falhas que um apego excessivo à honra que lhes é devida e, ainda que este tenha consequências trágicas, em geral seria forçado atribuir a elas maiores ligações com a violência coletiva do mecanismo de bode expiatório. Ao contrário, mesmo o caráter relativamente coletivo da morte em guerra é minimizado, todas as mortes em batalha sendo resultado de duelos entre heróis singulares e se, em Gilgamesh, pudemos ver uma transferência da violência potencial da coletividade voltada contra o herói para as divindades, na llíada este vínculo não é visível e a inimizade dos deuses não se liga à da coletividade.

Não obstante, há muitos sinais de crise de violência interna no exército grego, relacionada ao conflito entre Aquiles e Agamenon, toda a obra se passando no contexto desta crise provocada pela rivalidade. Podemos, ainda, ver no fim da obra uma atuação dos elementos positivos do sacrifício, de pacificação e reunião da comunidade, ligados à morte que, apenas neste sentido, podemos considerar sacrificial de Pátroclo e Heitor, a primeira trazendo o rei dos mirmidões de volta à guerra, marcando assim o fim da cisão no exército, e a segunda consolidando o retorno da ordem ao aplacar a fúria do herói, tendo mesmo um relativo efeito de reconciliação entre os dois lados da guerra, a epopeia se encerrando à altura da breve

\footnotetext{
${ }^{11} \mathrm{O}$ mesmo não é verdadeiro com relação à mitologia sumério-babilônica relativa à época dos deuses, em que há uma classe de divindades maléficas, próximas aos titãs gregos, caracterizada de modo bastante negativo, havendo interessantes traços da vitimação do bode expiatório em seu líder Kingu, o único a ser punido por sua revolta como condição para a reconciliação entre os deuses.

${ }^{12}$ HOMERO. The Iliad (tradução Samuel Butler), disponível em áudio em https://librivox.org/the-iliadby-homer-translated-by-samuel-butler/

${ }^{13}$ HOMERO. The Odyssey (tradução Samuel Butler), disponível em áudio em https://librivox.org/theodyssey-by-homer/
} 
trégua para os funerais do filho de Príamo após seu assassino ter concedido em devolver seu cadáver ao pai, que por isso lhe é grato.

Em tudo isso, poderíamos até tender a ver uma representação literária consideravelmente perspicaz de um conflito cuja dinâmica se aproxima da percepção girardiana da crise mimética, já que nascida da rivalidade. Nesse sentido, o fato de não haver projeção de traços monstruosos nos responsáveis pela crise ou naqueles cuja morte a resolve poderia parecer um avanço em direção a uma escapada da lógica sacrificial persecutória. Mas não é assim.

Temos concentradas nos heróis da llíada todas as qualidades positivas do sagrado: beleza, nobreza, aptidão guerreira sobre-humana e, para alguns, até mesmo a capacidade de refundar a ordem por sua morte. Uma ligeira sombra do sagrado negativo se faz sentir na crise consequente de seus excessos, mas isto é pouco demais para que o víssemos como o lado nefasto do bode expiatório como visto por seus perseguidores. Entretanto, o desprezível, nocivo e condenável não está ausente das epopeias homéricas, mas se revela de modo exemplar em outros personagens que não os heróis, o contraste tornando ainda mais claro o espírito persecutório que as obras incorporam com total conviç̧ão.

Há, primeiramente, o bode expiatório em sentido mais evidente, ao menos para nós, que é Helena, duramente condenada por sua fuga com Páris não só nas obras, mas em uma perene tradição, e assim vista como causa da guerra, das inúmeras mortes de heróis e da destruição de Troia. Essa tradição se liga à forte tendência de fazer das mulheres bodes expiatórios privilegiados, muitas vezes acusadas por disputas nas quais elas seriam antes vítimas que responsáveis. Apesar disso, ainda não é ela que nos interessa mais de perto, pois a despeito das duras críticas que sofre, a mais bela das mortais não passa por um processo persecutório realmente desenvolvido nas epopeias de Homero.

Os bodes expiatórios mais inteiramente consumados na llíada e na Odisseia são bastante menos centrais e aparecem de modo passageiro. Eles são ridicularizados e espancados, sofrendo uma violência de caráter coletivo e inclusive com virtudes reconciliatórias provisórias, em seguida não voltando a receber atenção. 
Falo do disforme Tersites e do mendigo Iro, ambos, curiosamente, encontrando no mesmo Odisseu aquele que leva a efeito o desprezo e a hostilidade que a coletividade Ihes dedica.

Assim, o que encontramos em ambas as obras atribuídas a Homero é a ênfase quase total na face positiva do sagrado, corporificada pelos heróis, não obstante a face negativa se mantenha presente de modo limitado na figura de personagens baixos, no que se revelaria até mesmo um espírito de classe elitista. Isso, porém, se dá de modo bastante diferente em ambas as epopeias, na llíada a divisão sendo ainda mais absoluta, enquanto na Odisseia a proximidade original do herói com a vítima execrada se esboça com insistência. Além disso, na segunda, mas talvez mais primitiva das epopeias homéricas, ainda outra forma da divisão épica em um sacrifício positivo e um negativo que terá importância particularmente na tradição da cristandade está presente: a condenação de uma coletividade persecutória não justificada em seu sacrificialismo, que por isso é sacrificada: o sacrifício dos sacrificadores.

Veremos isto um pouco mais detidamente na análise que se segue.

\subsection{Cara ou coroa: Odisseu, Tersites e Iro ${ }^{14}$}

No primeiro ensaio de seu monumental Mimesis $^{15}$, Auerbach afirma a constância da identidade dos heróis homéricos com eles próprios. Com o passar do tempo eles permanecem os mesmos, essencialmente inalterados tanto interna quanto externamente, em oposição aos personagens bíblicos que ao longo de uma vida, na relação com seu Deus e seu meio social, passam por grandes mudanças.

René Girard, por sua vez, afirma que todo herói mitológico, bem como toda divindade, possui traços ambivalentes, um aspecto positivo e glorioso, outro negativo, baixo e vil. Para ele, isso resulta da transfiguração mitológica de sua condição original

\footnotetext{
${ }^{14} \mathrm{O}$ texto que se segue foi originalmente redigido como trabalho de conclusão de curso para a disciplina Épica grega, ministrada pelo professor livre docente Christian Werner. A isso se deve o fato de que algumas das ideias anteriormente abordadas sejam aqui retomadas, por serem parte integrante da estrutura do texto.

${ }^{15}$ AUERBACH, Erich. Mimesis: A representação da realidade na literatura ocidental. São Paulo:

Perspectiva, 1987.
} 
de bodes expiatórios em um processo sacrificial (cujas especificidades para o autor serão abordadas mais à frente), transfiguração a qual passa por um ocultamento mitológico da violência coletiva sofrida pela vítima sacralizada.

O aspecto negativo destas vítimas transfiguradas se deve às acusações de crimes ou malefícios cometidos por ela, conduzindo a uma crise que se resolve com seu sacrifício, expulsão ou assassinato coletivo. Ainda para Girard, à medida que as tradições mitológicas se distanciam de suas fontes sacrificiais, a tendência é separar o mais possível as duas faces dos personagens sagrados, concentrando em alguns o elevado e o exemplar, enquanto outros carregam o baixo e o condenável, embora traços de ambos sempre se mantenham.

Os poemas homéricos certamente pertencem a um estágio em que esta última tendência vai bastante avançada, e talvez possamos associar a imutabilidade de seus heróis ressaltada por Auerbach a ela. Ela ajudaria a ocultar, não inteiramente, as mudanças da honra para o opróbrio e deste para aquela, tão importantes nos mitos que transfiguram o sacrifício girardiano. Ainda que não desapareçam por completo, em Homero o herói não carrega traços realmente desprezíveis, o envilecimento, ainda que, como veremos, chegue a se esboçar com bastante clareza, não o toca verdadeiramente. Nesse sentido, é ainda interessante que seja justamente aos personagens da Bíblia hebraica que o filólogo alemão contraste os de Homero, sendo nessa mesma tradição que Girard vê uma maior transparência, e mesmo denúncia, dos processos sacrificiais.

Com relação à ambivalência dos heróis tradicionais, Cesário Bandera afirma em seu grande estudo sobre Dom Quixote, "Despojada e despida": “(...) à sombra de um Aquiles vivia (...) o anti-Aquiles, a odiosa figura disforme, ridícula, desprezível, de algum Tersites". ${ }^{16}$ A frase é boa, mas talvez fosse ainda mais adequado substituir Aquiles por Odisseu, herói que entra em conflito mais direto com o desprezível personagem e que, como veremos, na Odisseia chega a uma posição bastante semelhante à sua. Como se sabe, ainda que em outra chave, teorias sobre uma depuração das figuras tradicionais dos heróis na obra homérica não são exclusivas de

\footnotetext{
${ }^{16}$ BANDERA, Cesáreo. “Despojada e despida”: A humilde estória de Dom Quixote: Reflexões sobre a origem do romance moderno. São Paulo: É Realizações 2012. p 26.
} 
Girard, Odisseu, em particular, sendo um dos que apresenta maiores indícios de haver passado por caracterizações mais negativas.

No canto II da llíada, o exército aqueu passa por uma crise. No canto I, a peste provocada pelo erro de Agamenon ao se recusar a devolver a filha do sacerdote Crises leva à dissensão entre os líderes, culminando com o perigoso rompimento de Aquiles. Embora dias se tenham passado sem serem enfocados pela narrativa, os acontecimentos do canto II se inserem nesse contexto. A despeito da dificuldade em amarrar algumas aparentes incoerências do texto - notadamente a proposta teste de Agamenon de abandono da guerra quando só tinha motivos para otimismo, o rei logo demonstrando não desejar que fosse acatada - o discurso de Tersites ajuda a unir as novas dificuldades ao conflito do canto anterior. Defendendo o abandono da guerra, o disforme personagem dá entre seus motivos a má liderança do Atrida, associando-a à incapacidade de impedir o rompimento de Aquiles e desejando seguir seu exemplo, além de, como ele, ofender o chefe máximo do exército.

Em seus ensaios sobre a peça Troilo e Cressida ${ }^{17}$, em que Shakespeare trabalha a temática troiana, Girard retira do discurso de Ulisses, em que lamenta a desordem que atinge o exército, o conceito de crise de degree, ocasionada pelo desrespeito à hierarquia por aqueles mais altamente posicionados nela e que têm o exemplo de seu desrespeito aos superiores seguido pelos subordinados. Embora a noção de organização de um exército que o dramaturgo empresta aos contingentes aqueus não corresponda à dinâmica perceptível em Homero, em que a autoridade de cada chefe em relação com os outros e no conjunto do exército parece instável, oscilando segundo fatores diversos, esta volubilidade mesma favorece a situação potencialmente crítica descrita na peça, a crise de degree podendo de fato se aplicar aos conflitos dos primeiros cantos da llíada. Que na peça seja Ulisses a formular esta visão da crise, preocupando-se particularmente com a reafirmação da ordem hierárquica, é significativo, pois também no clássico antigo Odisseu, enquanto um dos mais próximos a Agamenon, demonstra particular empenho em fortalecer sua autoridade e reestabelecer a unidade e ânimo combativo do exército.

\footnotetext{
${ }^{17}$ GIRARD, René. Shakespeare: Teatro da inveja. São Paulo: É Realizações 2010.
} 
Se para Girard a crise é sempre resolvida pela unanimidade sacrificial em torno de um bode expiatório, é isso que Odisseu oferece aos aqueus em assembleia. Ele oferece Tersites, que concentra em abundância traços vitimários - como se refere Girard às características físicas próprias a favorecer a exclusão de um indivíduo do coletivo e sua perseguição por el $\mathrm{e}^{18}$, os quais subsistem na caracterização de muitas divindades e heróis -, como alvo do escárnio unânime da assembleia.

Conquanto venha a proferir um discurso em oposição ao de seu antagonista, não é exatamente pela retórica que Odisseu o vence, já tendo obtido o favor geral ao golpeá-lo, vituperar e humilhar. Uma prova de a que ponto este procedimento sacrificial é eficaz entre os aqueus está no fato de que haja entre eles quem afirme os maus-tratos dispensados a Tersites como o melhor dentre os feitos de Odisseu, não, certamente, devido à proposta defendida pelo orador batido, já que este último não fazia mais que expressar o desejo que pouco antes movia todo o exército. Que a facilidade com que a massa se volta contra o personagem possa se dever a uma indisposição prévia contra ele devido a seus ataques constantes aos líderes não enfraquece o argumento, e que as deformidades físicas e o mau caráter se unam no mesmo personagem só reforça sua caracterização como bode expiatório potencial.

Há, ainda, a possibilidade de que a hostilidade contra Tersites se deva a seu desrespeito para com Agamenon, neste caso sendo preciso supor que em seu discurso ultrapassava o limite de desrespeito para com um superior (a atitude similar de Aquiles não tendo sido particularmente estigmatizada), o que se torna tanto mais fácil caso se aceite que o personagem seja plebeu. Neste caso, o caráter classista das tendências sacrificiais em Homero sai reforçado, o que terá importância mais à frente.

A união do exército tendo sido renovada em torno do escárnio de Tersites, Agamenon faz severas ameaças de punição a qualquer um que voltasse a rompê-la recusando-se a lutar. A ordem reafirmada, assim, pretende prevenir pelo estabelecimento de uma rígida regra o gênero de comportamento que ocasionara a crise que a precedeu, de maneira semelhante ao estabelecimento de tabus que, para Girard, segue ao assassinato fundador em uma comunidade. Esta nova ordem é então

\footnotetext{
${ }^{18}$ Conferir GIRARD, René. 0 bode expiatório. Op. cit.
} 
consolidada com os sacrifícios rituais aos deuses, que, por assim dizer, Ihe conferem oficialidade e a ligam à esfera transcendente.

Por tudo isso podemos ver que se em Homero há um ocultamento da condição sacrificial que caracteriza os heróis, isso não se deve a uma posição que rejeitasse a perseguição sacrificial em si, mas antes a uma que considera indigno do herói tê-la sofrido. Vemos também esta distinção entre os merecedores e os não merecedores de escárnio sacrificial, levado a consequências bastante drásticas, no tratamento dado na Odisseia ao retorno de seu protagonista à sua casa.

Sob o disfarce fornecido por Atena, a condição em que o rei extraviado regressa ao lar é socialmente desprezível: ele aparenta decrepitude física e parece desprovido de qualquer amparo por sua dupla condição de mendigo e estrangeiro; atributos mais que suficientes para fazer dele um excelente candidato a bode expiatório.

Mesmo a queda de uma posição honrosa para a abjeção está presente na narrativa do passado que Odisseu forja para si, mas, diferente do Jó hebraico (para manter o confronto de tradições feito por Auerbach) cujo livro todo é uma reflexão sobre a passagem de um líder respeitado para um mendigo desprezado, em Homero é tudo ficção. Pela necessidade de verossimilhança da estória, que visa o engodo, a possibilidade de um trajeto tão próximo ao que o herói poderia plausivelmente ter percorrido para chegar verdadeiramente àquele estado é afirmada, porém não sendo real.

O quão possível era para Odisseu se ver realmente reduzido ao estado que falsamente ostenta se faz sentir ainda em sua chegada entre os feácios. Ao atingir a ilha, tendo perdido todos os sócios, os bens, estando imundo e nu, sem o concurso do sobrenatural o rei dificilmente poderia pretender uma posição muito mais elevada que a de um mendigo em terra estrangeira.

Voltando à Ítaca, de início a maioria dos pretendentes trata Odisseu disfarçado com zombaria, mas sem particular malevolência, apenas alguns dentre eles levando os maus-tratos um pouco mais longe. Aos poucos, porém, a hostilidade se generaliza, havendo mesmo um momento em que sua presença provoca divisões entre o grupo, 
que por isso deseja expulsá-lo, não o fazendo pela proteção de Telêmaco. É, embora sem chegar às últimas consequências, um padrão sacrificial típico, em que o estrangeiro, portador de outros traços vitimários, é responsabilizado pelo conflito interno, perseguido e expulso. Há, inclusive, exemplos de outras mitologias em que isto se dá com um trickster, tal como Odisseu, no contexto de uma festa a que perturba.

Embora a atitude dos pretendentes seja condenada, isso não deve ser visto como um traço antissacrificial. Trata-se novamente da seletividade de vítimas. Embora as regras de hospitalidade devessem proteger o mendigo sob cuja identidade se disfarça Odisseu - que afinal teria sido um nobre e mantido laços de hospitalidade com o rei de Ítaca - vemos que sua proteção não se estende a todos. No caso de Iro, sim, temos um sacrifício unânime, com a devida anuência dos personagens positivos, do narrador, presumivelmente do público e mesmo a dos antagonistas, nos sendo mostrado o tratamento devido a um verdadeiro mendigo que não conheça suficientemente seu lugar e, embora não o saiba, desrespeita os melhores que ele (a consciência nunca pareceu particularmente relevante para o estabelecimento de culpa nos mitos gregos).

A cena do combate entre Odisseu e Iro é importante. O conflito é manifestação da perseguição sacrificial dos pretendentes a Odisseu, ocorrendo em uma disposição espacial típica do sacrifício, com a vítima no centro da multidão hostil em roda, e Iro deveria ser instrumento de sua agressividade ao, como julgavam certo, espancar facilmente o intruso e, de acordo com os termos da aposta, fazê-lo ser expulso do festim. O mendigo torna-se assim uma vítima substitutiva em mais de um sentido, tanto ao sofrer o destino preparado pela coletividade a Odisseu, satisfazendo-a temporariamente, quanto por sofrer previamente a punição que este destina aos pretendentes.

Por motivos distintos e de peso diverso, pretendentes, protagonistas e público consideram merecida a punição que os primeiros reservam ao mendigo derrotado: ser enviado ao rei Équito para ter o nariz e orelhas cortados e os genitais arrancados e jogados aos cães. O efeito do sacrifício de Iro é tal que leva mesmo a uma 
reconciliação temporária entre Ulisses e os pretendentes, que fazem votos de prosperidade ao herói disfarçado, o episódio se encerrando, novamente, com libações.

O desrespeito dos pretendentes às regras de hospitalidade na casa de seus anfitriões vem apenas somar-se a sua prévia atitude desonrosa durante a corte a Penélope e ao mais sério crime de haverem conspirado a morte de Telêmaco, assim como as afrontas diretas a Odisseu disfarçado - inspiradas por Atena, para insuflar ódio no herói, e certamente elaboradas pelo poeta com intenções semelhantes relativas ao público - vêm apenas a legitimar sua próxima tomada como bode expiatório coletivo devidamente digno da punição. Podemos associá-lo ao sacrifício dos sacrificadores, de que fala Hinkelammert em seu Sacrifícios humanos e sociedade ocidental: Lúcifer e a Besta ${ }^{19}$.

O conceito criado pelo economista e teólogo alemão radicado na América Latina se refere à utilização pela cristandade europeia da condenação ao sacrifício própria à doutrina cristã para justificar a perseguição e o sacrifício, mesmo ritualizado, de não cristãos acusados da prática de sacrifícios. No caso de Homero, não é o sacrifício em si a pecha que marca as novas vítimas, pois como já visto, sua prática não é estigmatizada, mas a perseguição a uma vítima protegida; isso, bem entendido, traduzindo a dinâmica do texto para um vocabulário sacrificial dele ausente.

Desta forma, podemos levantar a hipótese de que o conceito de Hinkelammert possa ser expandido e aplicar-se não apenas à cristandade, mas, com as devidas especificidades, a qualquer cultura em que o estágio de acentuada separação entre as duas faces do sagrado esteja em curso.

No final da Odisseia, Odisseu é restaurado à sua condição régia, com toques de sobrenatural advindos das dádivas de Atena, que o assemelham ainda mais a um herói divinizado ou deus ressurreto (estágio final da transfiguração mitológica da vítima) após passar muito perto de um sacrifício coletivo, que nos mitos mais arcaicos normalmente precede a transfiguração da vítima. Ele atinge, desta forma, a apoteose que coroa o processo sacrificial e frui da glória de seu polo positivo, sendo, no entanto,

19 HINKELAMMERT, Franz. Op. cit. 
poupado de seus aspectos ignominiosos, que não se dirigiam verdadeiramente à sua pessoa.

O sacrifício efetivo, porém, não deixa de se concretizar, embora com uma inversão dos papéis mais típicos, sendo a coletividade culpada a vítima sobre a qual a ordem abalada se refundará. Essa inversão, porém, traz alguns problemas.

Girard se alonga quanto à necessidade de que o bode expiatório seja desprovido de laços que possam levar alguém a procurar vingar sua morte. Na narrativa de seu passado ficcional, Odisseu se detém em ressaltar a confiança que depositava em suas alianças familiares, ora rompidas, ressaltando mais este aspecto fundamental da condição sacrificial em que aparentava estar. Também o caráter coletivo do sacrifício tradicional, em que é a própria comunidade a responsável pela morte da vítima, desencoraja a vingança, por não haver indivíduos particularmente responsabilizáveis contra os quais se voltar um possível vingador.

Tal condição de isolamento não é preenchida pelos pretendentes que, nobres, ao contrário, possuíam abundantes laços de aliança, pelo que a crise não se resolve definitivamente com sua eliminação, mas ganha em dimensões. Agora é contra toda a nobreza de Ítaca e boa parte do restante da Hélade que Odisseu deveria lutar. Daí a necessidade da intervenção externa de Zeus, como um espetacular deus ex machina (a intervenção de Atena, mais diretamente envolvida no enredo, não bastando para apaziguar ao menos o próprio herói), que se vê forçado a simplesmente decretar o término artificial das hostilidades, reafirmando a aliança entre Odisseu e as famílias dos pretendentes.

Podemos concluir desta análise que Odisseu compartilha a condição sacrificial com suas vítimas, Tersites e Iro, aos quais golpeia e humilha, conduzindo à zombaria coletiva e se reafirmando em dignidade ao fazê-lo. Estando, porém, em um estágio do tratamento mítico em que os elementos negativos e positivos do sagrado tendem a ser isolados, nele essa condição não passa de máscara, não atingindo sua essência. No herói, a coroa do rei oculta a face da vítima que, em seus antagonistas de condição inferior, se revela mais claramente, sendo exposta ao desprezo generalizado, dentro e fora do plano ficcional. 
4. Tendências do sacrificialismo na tradição épica pós-homérica: o sacrificialismo imperial e o sacrifício dos sacrificadores

Como vimos, nas duas epopeias homéricas que servirão de modelo para a emulação da épica latina e, por meio dela, para a ocidental em geral, há semelhanças e diferenças no tratamento dos elementos sacrificiais. Em ambas, os aspectos negativos da vítima sacrificial transfigurada são dissociados do herói e surgem projetados em personagens secundários unanimemente desprezados, na Odisseia, porém, a ligação do protagonista com essa natureza se deixa insinuar, ele chegando a ocupar uma posição sacrificial que não se consuma. Já na llíada, a ligação é imperceptível e, embora tomando ambas as obras em conjunto seja significativo o fato de que é o mesmo Odisseu a confrontar mais de perto a escória, de que em outros mitos se aproxima bastante, na narrativa do cerco de Troia ele, como todos os heróis, se encontra realmente livre de características negativas e lhe cabe um papel de sacrificador.

É a tendência da llíada que predomina na épica posterior. Na chamada "epopeia artificial" que é a Eneida ${ }^{20}$, da qual os fins intencionais de heroicização das origens da dinastia juliana são bem documentados, a sublimação dos heróis é total, quase nada restando do sagrado negativo, nem mesmo, ao menos para o protagonista, o "pio Eneias", na forma de excessos. O mesmo vale para a maior parte das produções épicas do classicismo cristão.

Não obstante, tanto nestas quanto em Virgílio, é essencial uma forte tendência a que podemos chamar sacrificial, embora não corresponda exatamente àquilo que Girard chama sacrifício mais propriamente: a ideia da necessidade de fazer guerra contra povos inteiros e conquistá-los em nome do ideal de um império, seja romano ou cristão, cujo estabelecimento e expansão são exigidos pelo divino.

Não tanto na Eneida, mas em boa parte das outras obras a que nos referimos, isso se liga ao outro aspecto do sacrifício presente na Odisseia já discutido: o sacrifício de uma coletividade sacrificadora culpabilizada, ou, o sacrifício dos sacrificadores.

\footnotetext{
${ }^{20}$ VIRGÍLIO. LA Eneida. Traduzido por OCHOA, Eugenio de, disponível em áudio em: https://librivox.org/la-eneida-por-virgilio/
} 
Quando isso não se dá, predomina, dentro de uma tendência a que talvez pudéssemos chamar "iluminista", uma concepção da guerra como uma fatalidade acidental, lamentável, mas justificada como exigência para a eliminação futura de toda guerra; sacrifícios exigidos pelo futuro estabelecimento da paz.

Como já discutido, o sacrifício em sentido comum mais literal é uma prática religiosa. Ele consiste no assassinato de uma vítima, humana ou animal, em contexto ritual, muitas vezes interpretado como sua oferta às divindades. Esse aspecto de doação, mesmo sendo considerado uma interpretação tardia, pode se autonomizar, assim incluindo no conceito a oferenda de objetos.

O sentido em que aqui a palavra é, principalmente, empregada é aquele da morte do bode expiatório no contexto de uma crise espontânea, a qual Girard acredita estar na origem do fenômeno religioso, ou fenômenos em que uma dinâmica próxima à sua se aplica. Entretanto, há ainda muitos outros sentidos da palavra na linguagem comum, já se afastando do sentido religioso, mas utilizando-o como metáfora. Muitas vezes a esses sentidos se aplica, mais ou menos perfeitamente, muito do sacrifício em sentido girardiano mais estrito.

Fala-se, por exemplo, em fazer sacrifícios por um ideal, causa ou mesmo por um objetivo material ou ganho de maiores vantagens. Neste caso, ao se aceitar o fim pelo qual se paga um preço como suficientemente valioso para justificá-lo, "sacrifício" pode assumir um sentido louvável, ou mesmo heroico, ao tratar-se do autossacrifício, ou ainda um de legitimação ideológica, ao se justificar as consequências impostas a terceiros de uma ação ou atitude como "mal necessário".

Ambas essas ideias de sacrifício, ainda quando a palavra não é empregada, são quase indissociáveis de qualquer discurso militar ou imperialista e, visto tais discursos sempre perpassarem o assunto épico, são via de regra perceptíveis nessa literatura. Não tanto em Homero, em que a falta de unidade nacional dos helenos e a ênfase no valor pessoal dos heróis faz com que sua disposição de se expor à morte e destruir os inimigos remeta basicamente à busca de glória pessoal, mas ao menos desde a Eneida isto é bastante claro, todas as agruras padecidas pelos sobreviventes de Troia, bem como a necessidade de guerrear contra as populações já estabelecidas no Lácio e 
submetê-las sendo justificadas como exigidas pelas divindades e o destino em nome da fundação do Império Romano, assim como todas as guerras que este fará antevistas por Eneias no submundo quando lhe é mostrada sua futura descendência no canto seis - são exigidas por sua defesa, expansão e imposição da justiça e da paz.

No discurso da Roma empírica, a morte de seus soldados é um sacrifício pela pátria e a dos inimigos um mal necessário em vista de sua segurança. Este duplo sacrifício militar, como em toda sociedade de caráter imperialista, cumpre, em grande medida, o papel de estruturação social atribuído por Girard ao sacrifício, já que o culto estatal aos mortos de guerra e a reunião contra o inimigo externo ou interno, no caso das muitas revoltas, têm um papel fundamental na definição da identidade coletiva ${ }^{21}$.

Esse sacrifício do inimigo não é jamais desejado, mas imposto por aqueles que o sofrem. Deste modo, mesmo a morte do outro chega a ser um sacrifício sofrido por aquele que deve carregar o fardo de matá-lo, assim como ninguém poderia lamentar mais que Eneias a fatalidade da guerra contra os lácios, a qual não foi ele a buscar afinal de contas não sendo nem mesmo um conquistador, mas desejando apenas integrar-se a eles como um só povo pelo casamento com a princesa Lavínia -, senão aqueles a quem vence. Ainda assim, de acordo com a especificidade da ideologia virgiliana, esses não são propriamente culpabilizados ou apresentados com traços particularmente negativos, a discórdia entre as partes sendo um acidente contingente - provocado pela indisposição temporária de Juno contra os teucros - e estando destinada a ser superada para que, reconciliadas as partes em contenda, reine a paz no Lácio, como um dia reinaria na Terra, cumprida a missão do Império de estendê-la a todo o globo.

Não obstante essa parcial inocência, a fatalidade se aproveita das falhas humanas para se produzir. Especialmente da inveja e da soberba de Turno, incapaz de se reconhecer como não sendo adversário à altura de Eneias, assim permitindo que este tome sem guerra seu lugar por direito divino como governante - de modo similar

\footnotetext{
${ }^{21}$ Esses elementos já se fazem bastante presentes na Atenas da Liga de Delfos, pelo que o tratamento do mito de Troia pode aproveitar de modo bastante distinto do homérico seus traços que se adéquam ao modelo sacrificial que discutimos. Por exemplo, em Eurípedes, a despeito de um forte questionamento dessa ideologia em algumas de suas peças, ela parece se manifestar de modo impressionante em sua Ifigênia. Conferir a análise da peça feita por Hinkelammert. Op. Cit.
} 
aos povos que não se submetem pacificamente à dominação romana, ou aos camponeses e escravos que vez por outra se revoltam - por isso se impondo a morte do herói, à parte isso, nobre e digno. O vencedor lamenta também esta morte singular, hesitando ao perpetrá-la após subjugar Turno em duelo, mas não pode deixar de cobrar a dívida gerada pelo derramamento do sangue de seus companheiros, sendo com seu golpe final que se encerra a obra, um tanto abruptamente, sem elementos de epílogo.

Pouco antes, ao aceitar apostar o destino da guerra em um duelo contra o sobrevivente de Troia - o qual ainda degenerará, por interferência divina, ou seja, da esfera do sagrado, em nova batalha antes que realmente se realize sob esta forma, assumindo, portanto, maiores características de crise coletiva - Turno, consciente de suas poucas chances, assume seu papel como vítima única, dizendo ser o responsável pela guerra e, portanto, o que deve pagar por todos. Desse modo, ainda que representado simpaticamente, Turno é na economia da Eneida um bode expiatório cujo sacrifício corresponde à visão ideológica de Virgílio e as tendências sacrificiais de sua sociedade às quais adere, representando todos os inimigos do Império Romano.

\section{O sacrificialismo na épica cristã colonialista}

O mesmo espírito imperialista foi assumido pelo cristianismo, embora com suas especificidades e variantes segundo tempo e espaço, para não falar nas correntes e linhas divergentes. A justificativa ideológica para as guerras de conquista cristãs foi a expansão da fé e o combate aos infiéis: pagãos, hereges, cismáticos e concorrentes pela herança da tradição hebraica, como muçulmanos e os próprios judeus. Em suma, um projeto de uniformização global das crenças segundo uma ortodoxia cristã legalista, tendente à valorização do espírito em detrimento do corpo e na qual todo o cristianismo recebe uma leitura sacrificial, oposta, segundo a leitura girardiana e das demais tendências libertárias do cristianismo, à visão predominante em seus textos fundadores. 
Onde quer que a isso se unisse a existência de um poder monárquico suficientemente centralizado, junto à expansão da fé figura com igual peso a expansão do Império. Essa união indissociável torna-se então o valor absoluto no horizonte dos que se punham a seu serviço, constituindo-se em um ídolo - por muito tempo ainda investido de toda a autoridade sagrada própria ao divino - pelo qual sacrifícios ilimitados são exigidos; tanto o autossacrifício dos que o aceitam quanto o holocausto dos que a ele se opõem ou simplesmente encontram-se involuntariamente em seu caminho.

No contexto do classicismo lusitano e luso-brasileiro, por exemplo, esta ideologia se manifesta, em parte pela emulação intencional, em parte pela proximidade entre o pensamento de Virgílio e ideais renascentistas ou iluministas. Os lusíadas ${ }^{22}$, recua algumas décadas em relação ao período de sua composição e trata dos primeiros êxitos das grandes navegações, apresentando-as como cumprimento da vontade divina, representada literariamente pelos desígnios dos deuses grecoromanos, mas remetendo explicitamente ao Deus cristão. Como no livro seis do épico romano, no terceiro e quarto cantos do lusitano toda a ação militar do reino, desde suas origens, é apresentada e heroicizada, embora aqui como rememoração, não profecia.

O famoso episódio do velho do restelo é, mais comumente, lido como colocando a claro as contradições intrínsecas à empresa colonial de Portugal, entretanto não é assim que o vejo. Ou antes, ele o faz, em parte, mas - colocando a questão em termos sacrificiais - sua principal função, longe de consistir em uma crítica do processo colonial, é destacar o autossacrifício heroico dos varões portugueses. Ao fazê-lo pelo prisma daqueles que não participam ativamente da empresa, as mulheres e os anciãos, o episódio assume com efeito tons de verdadeiro lamento, revelando a ambiguidade da aventura, porém, ao enquadrar-se na estrutura ideológica mais ampla, inconteste no restante da obra, vemos o sofrimento apresentado se converter inteiramente em nosso já conhecido "mal necessário", lamentavelmente impingido àqueles fracos demais para tomarem parte ativa no destino heroico da nação e

\footnotetext{
${ }^{22}$ CAMÕES, Luis Vaz de. Os Lusíadas. Disponível em áudio em: https://librivox.org/os-lusiadas-by-luisvaz-de-camoes/
} 
abnegadamente assumido por suas maiores vítimas, os homens que irão arriscar-se a perecer longe da terra pátria e permanecer insepultos nas águas do mar. Tal autossacrifício, para aqueles que partilham a visão de mundo da obra - abundantes até o presente em Portugal - não traz qualquer questionamento com relação à colonização, mas antes a enobrece e justifica. Mais que isso, qualquer reconhecimento do lado negativo do processo restringe-se àquele que recai sobre vítimas portuguesas, não sendo colocada ao menos a possibilidade de que o sacrifício imposto aos inimigos - ou se preferirmos: às populações das terras invadidas - não seja justo e necessário, tanto mais por ser obtido à custa do sacrifício português. Esta é a versão camoniana da condenação da guerra presente na Eneida, mas limitada apenas aos ônus sofridos pelo império nascente que se considera herdeiro do Romano, sem o lamento pelo inimigo que bem ou mal se faz presente na obra latina.

Estudei outra versão - também inserida no contexto do colonialismo lusitano desta ambígua condenação/justificativa da guerra em um trabalho sobre $\mathbf{O}$ Uraguai, em que ela se manifesta com várias diferenças. Sem me deter sobre essa obra, é interessante destacar que, nela, esta questão é, em certa medida, mais próxima do que se dá em Virgílio, havendo um verdadeiro lamento pela destruição dos indígenas das missões dos Sete Povos, idealizados e até mesmo mais heroicizados que os militares portugueses, tratados de modo excessivamente realista para se alçarem à categoria de heróis. Essa, porém, se mostra explicitamente como um sacrifício exigido pela paz entre Portugal e Espanha, além de ser apresentada como culpa exclusiva dos missionários jesuítas, demonizados e transformados em bode expiatório. Assim, tratase da já mencionada divisão do sacrifício em um sacrifício lamentável e digno de reverência sofrido pela vítima inocente, e em um sacrifício meritório do inimigo monstruoso, fonte dos conflitos, em torno dos quais se dá a refundação da ordem apresentada por Girard como resultado do sacrifício da vítima única, o que não se dá propriamente em Os lusíadas.

Encontraremos muitos dos elementos sacrificiais próprios à épica cristã, já assinalados, desprovidos da condenação, mais ou menos parcial, da guerra, na obra anterior La chanson de Roland, com cuja análise se encerrará este capítulo. 


\section{La chanson de Roland}

La chanson de Roland é uma canção de gesta do século XI na qual também há uma reconhecida influência de Virgílio. Entretanto, nela não há uma intenção programática de emulação dos modelos tradicionais, pelo que talvez possamos considerar que o aproveitamento de elementos da tradição épica que faz é mais livremente adaptado à ideologia própria de seu contexto de produção, refletindo-a mais diretamente. Isso vale também para os elementos sacrificiais nela presentes.

A própria lenda de Rolando pode, como dito no início deste capítulo, ser considerada um exemplo próximo de transfiguração mitológica, não propriamente de uma vítima sacrificada, mas ao menos de uma personagem histórica cuja morte recebeu um tratamento sacrificial. Rolando foi um prestigiado líder militar, companheiro de Carlos Magno, tendo sido morto ao atacar, para fins de saque, bascos cristãos. Em torno dessa morte banal e mesmo inglória, teceu-se toda uma lenda de traição e heroísmo, a figura de Rolando se tornando de grande importância para a consciência de identidade primeiro dos francos, e posteriormente da França unificada.

Em sua versão literária mais famosa, La chanson de Roland, podemos observar que a ideologia da obra e o éthos atribuído aos personagens são muito mais os de seu contexto de produção, o século XI, que os do período que tematiza. Assim, menos do que um espírito imperial, são os ideais feudais, pré-corteses, que predominam, sendo menos forte a ideia de expansão do Império que a de dedicação absoluta ao suserano, e embora a visão beligerante do cristianismo como única fé verdadeira e em particular sua oposição ao islã seja central, ela parece assumir menos a forma do projeto de imposição mundial que a de polo de uma rivalidade entre credos e povos.

Como observa Auerbach ${ }^{23}$, os valores e estruturas sociais atribuídos aos inimigos muçulmanos no poema quase em nada se diferenciam daqueles dos cristãos. Deste modo, a oposição entre os dois campos é inteiramente formal, reduzindo-se basicamente ao nome dos deuses adorados em cada lado. Esta oposição nominal,

\footnotetext{
${ }^{23}$ AUERBACH, Erich. Op. cit.
} 
entretanto, tinha um peso definitivo à época, a diferença entre o cristianismo e demais religiões sendo, normalmente, percebida não em termos de éticas distintas veiculadas por cada crença, mas de escolha do que realmente seria o deus verdadeiro, ou seja, aquele capaz de favorecer os que o adoram e conceder-lhes o paraíso, os demais sendo demônios enganadores.

Não obstante essa ausência de diferenças essenciais a nossos olhos, a escolha de fé equivocada não era vista como um mero engano, mas como uma iniquidade moral altamente culpável. Na Canção, ademais, a fé muçulmana é estranhamente apresentada como um insólito politeísmo, em que se adora uma espécie de trindade maligna composta por Maomé, Apollyon e "Tergament", assim se configurando mais claramente como idolatria, no sentido formal de adoração a deuses que em verdade não o são, sendo identificados como demônios. Além disso, os que praticavam tal idolatria, em geral, se mostravam naturalmente propensos a praticar atos iníquos, não, é preciso reforçar, no sentido de assumirem uma moral distinta daquela dos cristãos, mas no de violarem preceitos morais naturalizados, e que de fato dificilmente seriam negados em muitas culturas, praticando traições e covardias.

Neste sentido, bastante ao início da obra, os muçulmanos praticam uma vilania que deve caracterizá-los de modo negativo, reforçando a justiça de sua futura destruição: o rei de Saragoça, Marsile, mentirosamente se declara disposto a converter-se ao cristianismo, tornando-se vassalo de Carlos e lhe cedendo metade de seu reino à condição que ele retorne à sua capital em Aix onde posteriormente o encontraria para fazer-se batizar. À covardia representada em si por esse estratagema - o qual visa ganhar tempo e posteriormente permitir que o barão traidor Ganelon entregue aos inimigos a retaguarda do exército de Charles juntamente com Roland e outros de seus fiéis amigos - soma-se o fato de que, como garantia do acordo que pretendem romper, os muçulmanos oferecem seus filhos, portanto entregando-os à morte para se protegerem e ao reino. Aquele que o sugere ao rei chega mesmo a dizer que mais vale que os reféns percam as cabeças do que eles próprios perderem bens e honra. 
Como se vê, trata-se de um ato facilmente interpretável em termos de um sacrifício recriminável. Além disso, o ato, ainda que não seja apresentado literalmente como sacrifício e provavelmente não visasse uma aproximação, apresenta semelhanças com uma das formas de sacrifício religioso mais abominadas pelos cristãos: o sacrifício de crianças por seus pais ${ }^{24}$. Dessa forma, o horror inspirado pela perfídia do inimigo para com os próprios filhos, bem como seu culto a falsos deuses, o converte em uma turba monstruosa que pratica uma violência não justificada contra vítimas inocentes - ou ao menos relativamente inocentes, no caso dos próprios filhos -, o que faz com que sua destruição em nome de Deus seja exigida pela justiça. Novamente trata-se do sacrifício dos sacrificadores, de que fala Hinkelammert, agora no contexto cristão de que o autor parece julgá-lo exclusivo, embora já o tenhamos encontrado na Odisseia, por exemplo.

Mas, de fato, há grandes diferenças tanto entre a função do sacrifício dos sacrificadores nas duas obras, quanto com relação a sua atuação nas sociedades em que estas foram produzidas. Na epopeia de Homero, podemos considerar que os pretendentes se tornam um bode expiatório coletivo, mas não há na obra nenhuma comunidade que se estruture em torno de seu sacrifício. Além disso, eles não representam um grupo social, interno ou externo à comunidade grega, por oposição ao qual esta efetivamente construa sua identidade de grupo. Longe de serem bárbaros ou inimigos, pertenciam à elite das comunidades que, em sua multiplicidade, constituíam o universo grego e efetivamente se viam como um grupo por oposição ao restante do mundo; motivo pelo qual, como analisado na parte 3 deste capítulo, sua morte nem mesmo pode ter efeitos pacificadores no enredo.

Ainda se pensarmos na llíada, em que alguns chegam a ver um registro literário da constituição da identidade helênica a partir do conflito com um povo bárbaro, a oposição identitária entre os troianos e seus atacantes é de muito menor importância que a oposição entre muçulmanos e cristãos na Chanson de Roland, as diferenças

\footnotetext{
${ }^{24}$ Paradoxalmente, a despeito da condenação particular dessa forma de sacrifício amplamente difundida em certas culturas, o pensamento mais tradicional das religiões de matriz bíblica tende a interpretar a passagem essencial de Abraão e Isaque no sentido de exaltar a disposição do primeiro de sacrificar o filho a lahweh - assim como valorizam o sacrifício de Jefeté da própria filha -, desconsiderando que o desfecho do episódio e o contexto cultural em que se inscreve fazem dele uma oposição a tal prática, comum entre os povos entre os quais habitavam os antigos judeus.
} 
culturais entre os povos sendo ainda muito menos representadas do que no poema medieval, ambos os campos simplesmente cultuando os mesmos deuses, apresentados como uma realidade universalmente experienciada de modo imediato. Além disso, embora os troianos possam ser vistos como uma vítima sacrificada às pretensões de conquista gregas, eles não sofrem uma projeção de monstruosidade moral ou agem coletivamente de maneira que nos permitisse falar em sacrifício dos sacrificadores, a obra nem mesmo chegando a representar sua destruição.

Na Chanson de Roland, o papel do bode expiatório coletivo que são os muçulmanos é muito maior enquanto tal. Diferente do que ocorre com o inimigo militar nas epopeias clássicas - não mais os mesmos da época de seus autores - o texto transmite o ódio e o desprezo atuais e vivos contra este inimigo real, e tal sentimento é parte essencial do que forma a identidade dos cristãos representados e daquilo que faz com que seu público se identifique com eles. Mais, talvez, que os personagens, é o narrador quem faz declarações condenatórias e profere impropérios contra os maometanos, mas certamente as mesmas disposições são pressupostas entre os primeiros, que, de resto, não se abstêm de violência verbal contra os opositores.

Embora este fenômeno de constituição da identidade de um grupo por oposição ao inimigo externo - analisado por outros teóricos das sociedades - não corresponda perfeitamente à morte pacificadora que põe fim a uma crise mimética, Girard o interpreta no sentido de fazer do inimigo um bode expiatório. Além disso, sobretudo em seu último livro, Rematar Clausewitz ${ }^{25}$, ele trata os grandes conflitos entre povos em termos de reciprocidade e rivalidade mimética. Assumindo o conceito, criado pelo teórico militar prussiano, de escalada para os extremos e procurando interpretá-lo de acordo com a dinâmica do mimetismo, Girard vê como a essência da guerra a reciprocidade entre nações rivais que consideram uma à outra como uma ameaça.

\footnotetext{
${ }^{25}$ GIRARD, René. Rematar Clausewitz. São Paulo: É Realizações, 2011. Este livro, em que Girard procura com maior empenho aplicar suas teorias à história ocidental e ao período contemporâneo, possui ideias de grande interesse, contudo parece também ser um de seus livros mais questionáveis.
} 
Ligadas por esse vínculo, cada lado faz preparativos bélicos que considera como uma resposta à hostilidade do outro e que este considerará, por sua vez, como uma prova de sua animosidade. Assim, como os duplos miméticos em uma relação de rivalidade, os oponentes se tornam cada vez mais semelhantes em sua disputa mesmo porque a rivalidade militar é muito frequentemente acompanhada por uma rivalidade no plano cultural e, mesmo que em muitos contextos cada lado rejeite a cultura do outro e procure se fechar em sua especificidade e afirmar sua autonomia, o que de resto é típico do mimetismo, sempre há uma considerável contaminação recíproca, como demonstra a arqueologia que traça a difusão de elementos culturais desde a pré-história -, visto cada um responder simetricamente aos movimentos do oponente, os quais se tornam cada vez mais violentos e desembocam na tentativa de submissão ou mesmo aniquilamento total de um pelo outro ${ }^{26}$.

Evidentemente, essa dinâmica não exclui motivações de ordem aparentemente mais prática e racional, por exemplo econômicas ou visando supremacia política, e talvez se pudesse considerar que a reciprocidade é antes a forma assumida pelo conflito que sua motivação. Não obstante, uma coisa não exclui a outra, e o espírito de rivalidade e revanchismo entre povos com certeza tem peso concreto na eclosão de conflitos diretos, que não raro partem espontaneamente da população, contrariando os interesses dos estados, ainda que nesses casos alcancem dimensões limitadas ${ }^{27}$. Além disso, embora se pudesse pensar, abstratamente, que uma tal motivação fosse insuficiente para justificar algo da magnitude de uma guerra, pois bastaria que ambos os lados caíssem em si e abandonassem a animosidade mútua para evitá-la, sabemos que tal bom senso não está de fato ao alcance, pelo que a ameaça do rival torna-se um motivo dos mais concretos, além de ser extremamente explícito no discurso belicista

\footnotetext{
${ }^{26}$ Girard considera que a tendência à escalada para os extremos, embora subjacente a toda guerra, acentua-se a partir das guerras napoleônicas na Europa do século XIX, associando esse fato à ineficiência cada vez maior dos mecanismos sacrificiais para conter a violência em uma cultura desmitologizada pelo cristianismo. Na verdade, talvez pudéssemos considerar que a tendência era bastante intensa na antiguidade, visto não ser inteiramente raro que um povo fosse inteiramente exterminado na guerra, embora, de fato, as dimensões dos conflitos bélicos no mundo moderno tenham crescido enormemente e o advento da bomba nuclear agora torne possível a destruição não apenas de povos, mas de todo o planeta.

${ }^{27}$ Pense-se, como um exemplo aleatório, nos casos de violência entre muçulmanos e hindus na Índia e no Paquistão, que a despeito de sua pouca amizade não têm interesse em uma guerra efetiva.
} 
de todos os tempos, como ilustra o célebre "Ou Roma destrói Cartago, ou Cartago destrói Roma".

Embora de passagem, Girard fala da possibilidade de se fazer uma leitura das relações conflituosas entre a cristandade e o mundo muçulmano em termos de reciprocidade e da escalada para os extremos. A extraordinária expansão territorial do mundo muçulmano afetou, entre outras, terras cristãs, dando origem a fenômenos como a Reconquista e as Cruzadas (em geral mais violentas que as conquistas muçulmanas); o Império Bizantino foi conquistado pelos otomanos, e o colonialismo europeu escravizou inúmeros países de cultura islâmica; a partir do século XX o mundo ocidental mantém uma política de ingestão no oriente médio, que tem por reação o terrorismo islâmico, que por sua vez justifica ações militares extremamente abusivas por parte das nações ocidentais. Ao longo de todo esse processo, a disputa em torno da legitimidade das pretensões a uma herança religiosa de mesma matriz tem um enorme papel ideológico, bem como a rejeição/fascínio pela superioridade técnica e econômica que ora pertence a um ora a outro dos campos.

Voltando a Chanson de Roland, é evidente que esta dinâmica não é representada na obra de modo particularmente claro, mas é em seu contexto que ela se inscreve, e seus reflexos se fazem sentir nela. Para um leitor distanciado pelo tempo, o caráter de irmãos inimigos que assumem as duas culturas na representação que recebem na obra se faz sentir de modo quase cômico na já mencionada ausência quase total de diferenças reais presente nela e na pretensão de uma ruptura total e sobrenaturalmente fundamentada que com ela contrasta. Tudo isso, entretanto, é apenas um pano de fundo para o interesse central da obra, a bravura de Roland e sua morte, que agora começaremos a analisar.

Roland é um personagem de motivações bastante simples. Pouco mais há nele que uma valorização da bravura guerreira que o leva a ser um opositor ferrenho de qualquer proposta de paz, a lealdade ao imperador Carlos e uma devoção cristã formal, da qual parte essencial é o ódio aos muçulmanos. Tais qualidades devem bastar para fazê-lo um personagem extremamente simpático ao público do poema e, 
assim sendo, para tornar qualquer opositor seu um personagem odioso e digno de desprezo.

Este é o caso de Ganelon, seu padrasto e, contudo, seu desafeto pessoal. Quando a proposta de paz do rei de Saragoça provoca a oposição do protagonista, o vilão a defende. Para sua consternação, a perigosa missão de negociar a paz junto a Marsile, que já matara mais de um emissário, acaba recaindo sobre ele por sugestão de Roland. Ganelon, porém, termina por encontrar aí nova oportunidade para se vingar do inimigo, traindo o imperador e se comprometendo a fazer com que Roland vá à retaguarda do exército, permitindo assim que os muçulmanos o eliminem, livrando-se das maiores ameaças por parte dos cristãos. Deste modo, o traidor se revelando tão pérfido e indigno como o inimigo da fé cristã, e, portanto, tão merecedor de punição quanto este.

A aceitação do pacto de Marsile por Charles é tão relutante que leva os intérpretes a considerá-la uma incoerência da obra, como se os cristãos estivessem inteiramente convencidos de que seriam traídos e ainda assim aceitassem cair na armadilha. Outra aparente incoerência relacionada diz respeito à forma como, sem motivos claros, o soberano parece se ver obrigado a aceitar a sugestão de Ganelon de que Roland ocupe a perigosa posição que levará à sua morte. Para tornar esses pontos mais coerentes, talvez pudéssemos imaginar que a obra pressuponha - embora sem se preocupar em explicitá-lo rigorosamente - alguma espécie de moral segundo a qual seria desonroso atacar um inimigo disposto a converter-se e jurar vassalagem, por um lado, e por outro uma covardia procurar se esquivar ao perigo de uma possível armadilha.

Ao menos no caso de Roland, esta última motivação é bem clara, sendo ele que exige ocupar a posição a que Ganelon quer obrigá-lo malgrado as objeções do tio e imperador, o que não o impede de vê-lo como nova razão para odiar o companheiro inimigo. Desta forma, a morte que sofrerá adquire traços de sacrifício voluntário e enobrecedor, típico dos personagens míticos ligados predominantemente aos aspectos positivos do sagrado e do sacrifício. Tal caráter voluntário da morte do herói torna-se ainda mais claro em sua recusa em tocar a trompa, advertindo a Charles do ataque que 
sofriam assim salvando a si e aos companheiros, mesmo frente aos sucessivos ataques de tropas que os superavam em número cada vez mais, fazendo-o apenas quando já é tarde demais para que fique claro que ele não pede por auxílio, mas apenas por vingança.

Em meio à batalha, os elementos religiosos, sempre sob a forma simples que têm no poema, são de grande importância, fazendo dos cristãos em desvantagem numérica mártires mortos por sua fé, enquanto os muçulmanos são associados diretamente ao demônio. Assim, os cristãos assumem efetivamente o papel de vítima inocente, diabolicamente sacrificada por uma coletividade monstruosa, e que por essa culpa é, por sua vez, sacrificada em nome de Deus. A eliminação mútua da retaguarda do exército cristão e da quase totalidade das forças do rei Marsile e seus aliados contém, a um só tempo - embora devidamente separados, como corresponde ao modelo cultural em que foi produzido o poema - os elementos do sacrifício ligados aos aspectos positivos e negativos do sagrado, um sacrifício da vítima inocente e o sacrifício dos sacrificadores.

Em meio a tal mortandade, porém, a morte de Roland se destaca e individualiza acentuadamente, assim ele podendo ocupar a posição de herói sacrificial cultuado. Ele é o último dos cristãos a morrer e não há qualquer um a quem seja atribuída individualmente esta morte, que então se torna verdadeiramente perpetrada pela coletividade dos maometanos. Moribundo, ele agoniza em um local afastado, no topo de um monte, e após fracassar na tentativa de quebrar a lâmina de sua famosa espada Durandal (a qual se torna uma relíquia) para que não caia nas mãos do inimigo, sua alma é levada por um anjo, assim, se ligando ao sagrado e contendo ao menos os germes de uma divinização da vítima ${ }^{28}$.

Esta morte é, com certeza, o centro da obra, que desse modo tem o sacrifício do herói como a base que dá sentido aos acontecimentos que a precedem e a ela se seguem. Já morto Roland e desbaratadas as forças do rei Marsile, o qual perdeu o filho e teve um braço decepado, o desespero reina em Saragoça, onde a derrota leva os muçulmanos a repudiarem seus deuses, destruindo suas estátuas. Entretanto, Charles

\footnotetext{
${ }^{28}$ Claro que a morte de todo bom cristão pressupõe sua ida ao céu, mas a do herói é a única narrada com elementos diretos do sobrenatural.
} 
tem ocasião de se vingar pela morte de seus súditos com a chegada das forças, ainda mais colossais, do Emir da Babilônia.

Nesta segunda leva de batalhas, o inimigo muçulmano de terras longínquas recebe ainda muito mais traços de monstruosidade que na primeira. Além de sua associação com a cidade que por excelência representa o mal na Bíblia, os povos que vêm retomar a luta dos muçulmanos de terras europeias, mais realisticamente representados, possuem características físicas irreais, como terem o corpo inteiramente coberto de pelos ou a pele tão dura que os dispensa do uso de armadura, por fim o Emir possuindo uma longevidade sobrenatural, sendo contemporâneo dos heróis de Homero. Tudo isso apresenta esta segunda fase da obra como uma luta quase direta contra as forças infernais, cuja derrota significa a vitória de Deus e o retorno da ordem cristã às terras disputadas, sendo selada com a conversão voluntária da rainha de Saragoça.

Neste ponto, para que a obra possa se encerrar sem pontas soltas, falta apenas a punição do traidor Ganelon, que terá o papel de bode expiatório individualizado, responsabilizado pela catástrofe coletiva unanimemente condenado. No tratamento deste vilão, é muito visível o mecanismo de bode expiatório sob sua forma mais ingênua, inteiramente autorizado pela obra.

A punição do traidor, na verdade, se inicia tão logo a trompa de Roland dá a Charles a certeza de que os muçulmanos os haviam traído, o que, com uma surpreendente falta de indícios, o leva a estar certo também da culpa de Ganelon. 0 fato de que esta seja real na obra, não altera o de que aquilo que ela constrói é um mecanismo persecutório irracional, pois os seus personagens não poderiam compartilhar nosso saber a esse respeito e, de acordo com o processo típico de sua época - correspondente a uma tendência subjacente a todas as sociedades, ainda que contida por mecanismos legais diversos - uma acusação, ao ser mimeticamente aceita na coletividade, adquire peso imediato de certeza ${ }^{29}$. No caso, a acusação ainda possui traços de confirmação do plano sobrenatural, visto partir do próprio imperador - o

\footnotetext{
${ }^{29}$ Girard abre um de seus mais importantes trabalhos, $\mathbf{O}$ bode expiatório, com uma análise de como fenômenos similares levam os cristãos a fazerem dos judeus bodes expiatórios durante a peste negra, e como isto se revela em uma obra de Guillaume de Machaut, de data relativamente próxima à da Chanson de Roland.
} 
que em um plano realista, aliás, justificaria a facilidade de sua aceitação, visto sua posição fazer dele um dos mais poderosos modelos miméticos imagináveis -, que julga ter recebido uma advertência divina em sonhos.

O nobre receberá um julgamento, mas este - o que já constitui um avanço com relação a manifestações mais diretas do mecanismo sacrificial - servirá apenas, como era corrente na inquisição, como um reforço da certeza da culpa e uma legitimação da perseguição. Portanto, a averiguação futura dos fatos não exclui que o acusado seja violentamente punido de imediato.

Tal punição tem um caráter coletivo e típico do tratamento dispensado ao bode expiatório. Para começar, ela é delegada aos cozinheiros do exército, o que, por sua baixa condição social, significa um rebaixamento do nobre Ganelon, que é por eles despido, surrado e tem cada fio de sua barba arrancado antes de ser amarrado e jogado ao lombo de uma besta de carga. Além disso, este primeiro estágio de sua execução torna sua morte mais inteiramente um ato da comunidade como um todo, não lhe dando o aspecto de um assunto interno da alta nobreza.

Já após a vitória, o exército reconduz Ganelon, a rainha Bramimonde e os corpos de Roland e seus companheiros à capital do Império, Aix, onde serão os instrumentos da refundação da ordem com que se conclui a obra. Antes de ser julgado, Ganelon é novamente flagelado em público, para apenas então receber o direito de defesa. Ele não nega seus atos, mas apenas seu caráter de traição, considerando-os uma vingança legítima contra Roland.

A maioria maior parte dos súditos de Charles estão contra Ganelon, mas, reforçando a necessidade de unanimidade que Girard considera condição essencial para o mecanismo sacrificial, a morte do vilão é entravada pelo apoio que este recebe de seus parentes, em particular Pinabel. Apenas essa cisão na unanimidade bastaria para impedir o mecanismo sacrificial de chegar a seu término, e o imperador Charles já se conformava amargamente em abrir mão de sua vingança, quando essa é salva pela instituição do ordálio, que poderia garantir por confirmação divina a justiça do sacrifício de Ganelon e prevenir que, em lugar do efeito pacificador que deveria produzir, ocasionasse novos conflitos. 
Outro elemento do espírito sacrificial que se revela nesta passagem é o risco que aqueles que eventualmente tomem o partido de um bode expiatório correm de partilhar sua condição, pois Charles exige trinta reféns dentre os parentes do traidor para que o duelo possa ocorrer. Este, entretanto, se dá e Pinabel é vencido por Thierry, ao qual é atribuída a proteção divina, neste ponto não havendo mais dúvidas e se afirmando o acordo geral entre os juízes.

Todo o processo se dá no dia de São Silvestre, em meio a missas e rituais religiosos, o que reforça, ainda, sua ligação com o sagrado. No mesmo dia, tão logo são executados de modo infamante Ganelon e seus parentes, se dá o batismo de Bramimonde, cujo nome se torna Julienne, o que, como mencionado, marca a vitória do cristianismo sobre os sarracenos na Europa.

Deste modo, La chanson de Roland se conclui em um dia santo com a fundação de três bases simbólicas em torno das quais se sustenta a cultura que a produziu. De um lado a punição daqueles que rompem a unidade interna do império cristão e trazem o conflito intestino à sociedade, simbolizada na morte de Ganelon; de outro, as honrarias e o estabelecimento de um culto à memória de heróis que são propostos como modelos para o éthos nacional e cuja morte é um dos motivos para a condenação do inimigo muçulmano, de que Roland é o símbolo máximo; e por fim, a consolidação do território em que reina a lei emanada do divino na Europa, o que traça os limites entre o dentro e o fora da comunidade cristã e a define por oposição ao rival demonizado, de que a aceitação voluntária da fé cristã pela rainha Julianne é o símbolo. Com isso, a obra representa o que seria um momento crucial da fundação da sociedade cristã no ocidente, com a consolidação de uma das fronteiras do império Carolíngio, apresentando diversos dos elementos sacrificiais que Girard encontra em suas análises de mitos, sob a forma em que há uma separação em campos bastante distintos dos elementos positivos e negativos do sagrado, que em outras culturas podem ser vistos indissociados. Ao fazê-lo, de modo bastante simples e, possivelmente, inconsciente, ela fornece uma dada visão de sua cultura, justificando as pretensões de legitimidade do poder nela estabelecido e sua ação militar contra o inimigo externo. 


\section{Apêndice: 0 sacrifício e a Glória}

Pensando nas duas palavras gregas que usualmente são traduzidas por "glória", Kleos, em contexto homérico, e Doxa, em contexto religioso ou político, podemos ver que aquilo que une a ambas é seu caráter de reconhecimento público, preferencialmente unânime, do valor de um indivíduo, herói, político ou divindade. A kleos se concretiza na fama adquirida pelo guerreiro em suas façanhas, principalmente sob forma de canções inspiradas pelas musas aos aedos, e a doxa em práticas públicas, espontâneas ou cerimoniais, tais como a aclamação de um general triunfante, de um Imperador, ou o louvor oferecido a Deus em uma liturgia. Essas práticas, porém, de um modo por vezes um tanto obscuro, não são vistas como a fonte da glória daqueles a que se glorifica, mas como uma resposta à glória que já possuem, embora esta dependa delas para existir. Por isso, Agamben ${ }^{30}$, após discutir longamente as concepções cristãs da glória, tanto a terrena como a intrínseca a Deus, termina por localizar a verdade que sustentaria as práticas ligadas a ela em concepções não cristãs que veem a glorificação como uma necessidade das divindades, cuja vida e o poder dependem das orações, ritos e, particularmente, sacrifícios, executados pelos seres humanos.

Não é difícil ver no desejo mimético pelo ser, como trabalhado por Girard, um elemento capaz de ligar a realidade empírica das práticas de glorificação com a concepção de criação e nutrição das divindades por meio delas, presente em várias culturas. Como já visto, para Girard, o desejo busca, para além dos objetos em que se concentra acidentalmente, o preenchimento da carência de ser a que todos estão sujeitos. Em sua forma mais pura, embora com maior potencial de produção de violência, esse desejo se desprende dos objetos, e passa a buscar o reconhecimento de seu valor intrínseco pelo outro, para assim, ao mimetizar a visão alheia de si mesmo, poder se convencer da posse deste valor.

Em muitas culturas esse valor é, em maior ou menor grau, substancializado e visto como uma força sobrenatural. Juntamente com a substancialização da violência que parece se apoderar de uma coletividade a partir de fora, esse valor advindo do

\footnotetext{
${ }^{30}$ AGAMBEN, Giorgio. O Reino e a Glória: uma genealogia teológica da economia e do governo. São Paulo: Boitempo, 2011.
} 
reconhecimento alheio é o que Girard chama de sagrado, correspondendo, por exemplo, à famosa concepção polinésia de mana, força mágica cuja posse por um indivíduo, um chefe guerreiro, por exemplo, depende do maior ou menor reconhecimento dela pelos demais. Também a glória, particularmente doxa, corresponde a isso, embora de modo já bastante menos substancializado.

Os líderes políticos, ou pretendentes a tal, disputam por essa glória como um bem em si, além de que sua posse se converte em poder concreto sobre a massa, do que são provas, em contexto romano, a aclamação como Imperador ou a aprovação aclamatória imediata a uma proposta política. À medida que se torna cada vez menos espontânea e mais rigidamente prescrita por um cerimonial, a glorificação perderá seu efeito concreto mais direto, mas manterá a mesma função como sustentáculo do poder e confirmação de um valor sobre-humano, já presente em seu objeto.

No que diz respeito à glorificação das divindades, a reflexão de Agambem e a teoria de Girard são complementares. Esta última procura demonstrar como, para além da ideia de alimentar o poder das divindades pelo sacrifício, este as criaria historicamente pela divinização da vítima sacrificial, como já discutido anteriormente. Essas ideias, porém, tornam mais claro um aspecto consciente da maioria das práticas rituais, o qual Girard leva pouco em conta, e nos permite supor que, além dos fins inconscientes de controle da violência e refundação da ordem, os ritos buscam fazer o mesmo às divindades que faz a seus líderes (por vezes divinizados): alimentar seu poder e satisfazer seu amor próprio pelo reconhecimento deste poder e de sua superioridade intrínsecos ${ }^{31}$. Novamente, independentemente da aceitação de tais

\footnotetext{
${ }^{31}$ Quanto às dificuldades que a glorificação de Deus oferece para o pensamento cristão, embora menos relevante para o objeto desta pesquisa, podemos, de passagem, fazer uma associação com o pensamento de Girard. Na concepção cristã, em que Deus não é propriamente um ser e possui a plenitude máxima de todos os bens, sua glorificação parece desprovida de sentido, pois não poderia acrescentar nada a sua glória intrínseca. Agambem vê todas as principais tentativas tradicionais de justificar a necessidade de glorificar a Deus como paradoxais e se concentra - não ignorando a engenhosidade de tais tentativas, mas buscando incorporá-las como altamente significativas - em sua função legitimadora do poder terreno, concebido à semelhança dos modelos teológicos do governo do mundo por Deus. Sem negar essa função, ao menos uma das explicações que o autor nega, acredite-se ou não nela, não me parece contraditória nos próprios termos, aquela de que a glorificação de Deus pelos homens não é uma exigência, e muito menos uma necessidade, de Deus, mas uma resposta espontânea daqueles a sua glória intrínseca. A glória de Deus, não apenas segundo esse modelo, seria o reconhecimento mútuo de cada Pessoa Divina pelas demais no seio da Trindade, reconhecimento o qual nega qualquer dependência de umas com relação às demais. Tal reconhecimento recíproco livre de rivalidade é correspondente à possibilidade de um mimetismo não conflituoso e da boa reciprocidade
} 
realidades metafísicas, este modelo certamente influenciou a concepção girardiana, bem como a hegeliana do reconhecimento, a qual também é uma das principais influências de Girard via Kojève, como o autor reconhece em Rematar Clausewitz ${ }^{32}$.

Voltando à esfera humana. A kleos é, talvez, menos próxima do sagrado, em sentido girardiano, mas também ela é a busca de reconhecimento e confirmação do próprio valor, projetada, mesmo, para além da morte do herói. Além disso, no contexto homérico, mais próximo da doxa é o conceito de timê, comumente traduzido por "honra", o tratamento condigno de um herói por seus pares e subordinados, motivo de inúmeros conflitos, entre os quais aquele entre Aquiles e Agamenon. Desse modo, ainda quando não aparece explicitamente, é clara a importância da glória, analisável em termos miméticos, para a literatura épica. Ela é, enquanto kleos, a motivação para os feitos bélicos dos heróis, enquanto timê a de seus conflitos uns com os outros e enquanto doxa aquilo que os soberanos visam para si, seus súditos pretendem dar-Ihes e, principalmente no cristianismo, o que as conquistas territoriais procuram reforçar em Deus.

Fora isso, embora normalmente menos visível nessa literatura, que se preocupa sobretudo com as altas camadas sociais, também é a glória, como reconhecimento coletivo do valor e do mando de uma pessoa, instituição ou divindade, o elemento mimético que, juntamente com o ódio a seus bodes expiatórios, dá unidade a uma comunidade e the confere sua identidade.

entre os seres humanos afirmada por Girard, a qual dependeria da aceitação da relação de Jesus com Deus Pai como modelo mimético não conflituoso. Jesus sendo a encarnação terrena da Pessoa Divina do Filho, sua relação terrena com o Pai seguiria o mesmo modelo da Economia Divina na Trindade.

${ }^{32}$ GIRARD, René. Rematar Clausewitz: além da guerra - diálogos com Benoî Chantre. São Paulo: É Realizações, 2011. 


\section{2- O sacrifício cômico}

\section{Algumas questões}

No capítulo precedente estudamos o herói sacrificial na épica séria. É preciso, agora, examinar sua contrapartida na literatura cômica, a qual não é apenas uma alternativa de gênero, mas de certa forma a sua outra face, como já vimos brevemente em nossa análise do personagem Odisseu.

Os heróis e divindades que na épica são marcadamente positivos, mas que em sua origem mítica eram ambíguos e seguiam mantendo traços disso em maior ou menor grau, podem receber um tratamento que enfatize seu lado negativo. Se isso for feito em uma visada séria, se tornarão personagens de tragédia, seguindo dignos do mais alto respeito; se for feito à luz do cômico, se tornarão personagens de comédia.

Nas mitologias em que a fronteira entre o sagrado positivo e negativo foram fortemente delimitadas, a ênfase no positivo na literatura séria resulta em divindades e heróis, e a ênfase no negativo em monstros, quer morais, quer sobrenaturais. Já na literatura cômica das mesmas culturas, há uma grande tendência a unir novamente ambas suas faces nos personagens bufos - assim como em mitologias em que a diferenciação é menos forte as personagens mais sagradas podem ser extremamente grotescas e ridículas - havendo, contudo, uma tendência ao negativo, ainda que apreendido sob uma luz simpática.

A literatura cômica, porém, coloca algumas dificuldades, as quais devemos tentar evitar. A primeira é que não nos devemos deixar enganar por essa simpatia com relação aos traços negativos dos personagens cômicos, que apesar dela, como veremos, permanecem em maior ou menor medida estereótipos vitimários capazes de justificar a perseguição transfigurada de bodes expiatórios. Muitos elementos sacrificiais que já encontramos na literatura séria são também típicos da cômica em uma versão, para falar com Bakhtin, carnavalizada, embora a visão da carnavalização

aqui adotada seja muito distinta daquela do autor russo. Além de que, segundo a interpretação girardiana, as festas carnavalescas são ritos visando uma reprodução 
controlada da indiferenciação mimética, culminando no sacrifício que refunda a ordem séria e, na visão bakhtiniana, opressora; se fizermos um exercício e apenas transferirmos certos episódios da literatura cômica para um plano realista, veremos que estes nos parecerão muito pouco próprios para inspirar o riso.

Outro perigo, provavelmente mais difícil de evitar ao seguir Girard, é o risco de, ao contrário, tomar a literatura cômica a sério e em tom reprobatório demais. Muitas vezes o riso, de fato, cumpre a função de relativizar o aspecto cruel da vida e mesmo combater suas fontes ao fazê-lo, como atualmente parece ser a interpretação mais corrente do cômico. Ambos esses aspectos nem sempre estão inteiramente dissociados, o que torna a tarefa do intérprete mais difícil, em alguns casos talvez nos cabendo antes assinalar os elementos de cada um em uma mesma obra ou até episódio, quando muito notando o pendor maior para um dos lados.

Ainda outra dificuldade reside em que nem toda comicidade apresenta grande relação com o sacrifício, podendo se dever, por exemplo, à quebra de expectativas ou, ao contrário, ao seu preenchimento excessivamente repetitivo, como destacado por certas teorias, ou ainda à discrepância entre conceitos ou ideais e a realidade ${ }^{33}$. Principalmente em obras mais tardias, esses elementos podem predominar, às vezes de modo bastante inocente e pouco interessante para nossa análise. Quando, porém, essas formas do cômico estão a serviço da sátira, podemos considerar, tanto mais quanto mais cruel essa for, que eles próprios são sacrificiais, já que, se não apresentam qualquer representação do sacrifício no interior da obra, nos oferecem suas vítimas como bode expiatório a ser sacrificado pelo riso zombeteiro e cruel da coletividade representada por seu público.

Não acredito que seja uma afirmação excessivamente forte, pois muito frequentemente as vítimas da sátira pertencem aos grupos mais expostos a se tornarem bodes expiatórios reais na sociedade em que a obra é produzida, como estrangeiros, grupos étnicos minoritários ou explorados, escravos, mulheres, loucos ou mesmo os poderosos locais, que ao vacilarem em certas conjunturas podem sofrer as mais espetaculares quedas. Nesse sentido, nosso Boca do Inferno apresenta um

\footnotetext{
${ }^{33}$ Para uma discussão das teorias de Bergson, Schopenhauer e outros ver HOSLE, Vittorio. Woody Allen: filosofia del humor. Barcelona: Tusques Editores, 2002.
} 
compêndio sacrificial dos mais completos. Não cabe esquecer que, na vida social, ser alvo de zombaria generalizada é um dos destinos mais temidos, podendo levar a consequências como o suicídio ou a completa marginalização.

Por outro lado, é claro, além do sacrificialismo aceito pelas obras, a temática sacrificial também pode estar presente na literatura cômica através da terceira via de que falei no primeiro capítulo: a percepção crítica das tendências sacrificiais na tradição e na sociedade contemporânea. Nesse caso, muitas vezes a grandeza da literatura cômica é recuperar aqueles que são objetos tradicionais da zombaria coletiva, como faz Don Quijote com o louco, ou ressaltar a crueldade do riso, como ocorre em Policarpo Quaresma, cuja primeira parte se encerra com a internação do protagonista em um hospício em decorrência da zombaria generalizada.

Passemos, agora, à análise concreta destas questões em algumas obras canônicas da tradição cômica.

\section{A manipulação dos mecanismos sacrificiais em Aristófanes}

O material principal das comédias de Aristófanes é a vida político-jurídica da Atenas de sua época em sua conexão com a constante crise social representada pela Guerra do Peloponeso. Com posições variáveis quanto à necessidade da paz ou da continuação do conflito, o que não varia é a intensidade de seu ataque contra aqueles que considera nefastos para a cidade por defenderem posições contrárias às suas.

Poderíamos dizer que o autor de As nuvens demonstra clara consciência do sacrificialismo inerente à vida pública ateniense, mas, longe de recusá-lo, procura manipulá-lo, indicando aqueles que julga deverem ser suas vítimas de modo bastante explícito. Um exemplo significativo é o caso de Cleofonte do qual diz na parábase de As rãs, que deveria ser assassinado durante uma votação, poucos anos mais tarde exatamente isso se dando. Com isso não quero dizer que foi a peça do autor a motivar 
tal crime, mas ressaltar o quão profundamente Aristófanes assumia tendências de sua época que podiam chegar ao extremo e as reforçava por meio de sua obra popular ${ }^{34}$.

Aqui cabe voltar brevemente a nossa já conhecida doxa, agora não no sentido traduzível por glória, mas naquele criticado pelo Sócrates de Platão, traduzível por "opinião". Essa, que Sócrates opõe ao saber filosófico obtido a partir do questionamento sistemático das aparências, é um julgamento fácil e generalizado com base na aceitação irrefletida dessas mesmas aparências pelo povo. Unindo-se ao sentido de glória por esse caráter em grande medida mimético de opinião coletiva tendente à unanimidade, é a doxa que exalta heróis e demagogos, bem como condena criminosos e traidores, julgando sobre o ostracismo ou a pena capital, sendo em grande medida ela que levou à morte de Sócrates, embora este a pudesse ter evitado ao se declarar culpado e pagar uma multa, ou seja, ao se conformar à unanimidade que o condenava. De passagem, interessa, ainda, o fato de que, segundo Agamben ${ }^{35}$, doxa seja o termo no grego moderno para designar a opinião pública ligada aos meios de comunicação.

Na peça $\mathbf{A} \mathbf{P a z}^{36}$, essa percepção do caráter manipulável da opinião ateniense e de sua tendência à violência coletiva aparece de modo bastante interessante. Nela, o autor não chega a pregar o assassinato de seus desafetos, embora se regozije com a morte de alguns, e passa perto de uma crítica do sacrificialismo ateniense, entretanto mantendo demais do seu espírito.

Nela, o agricultor Trigeu, cansado da guerra, sobe ao Olimpo montado em um besouro gigante com a intenção, segundo diz, de convencer os deuses a trazerem de volta a paz ou, caso não o consiga, mover contra eles um processo de traição, pois favoreceriam aos bárbaros ao fomentar discórdias internas entre os gregos. Essa é uma entre muitas ironias contra a "mania" dos atenienses de irem aos tribunais, e nela podemos ver, talvez para além da intenção do autor, uma alusão ao fato de que tais

\footnotetext{
${ }^{34}$ Caso similar dá-se com Charles Péguy, que pouco antes da eclosão da Primeira Grande Guerra afirmou em um artigo de jornal que o político socialista e pacifista Jean Jaurès deveria ser assassinado, o que se deu poucos dias depois. Que ambas as vítimas tenham atraído o ódio contra si por se oporem à guerra (com melhores ou piores motivos) é uma coincidência significativa.

${ }^{35}$ AGAMBEN, Giorgio, op. cit.

${ }^{36}$ ARISTÓFANES. A Paz, em: Menandro e Aristófanes - Coleção Universidade. Rio de Janeiro: Edições de Ouro.
} 
julgamentos muitas vezes se relacionavam a uma tendência de se fazer de figuras políticas preeminentes, mesmo os deuses, no caso, os bodes expiatórios pela guerra ou os revezes sofridos nela por Atenas.

Não obstante, a mesma tendência se revelará, aparentemente apoiada por Aristófanes, na explicação dada pelo deus Hermes das causas da guerra. Em uma típica acusação leviana das que se faz a políticos - leviana ainda quando possa conter elementos de verdade - o filho de Zeus afirma que o líder político extremamente popular que foi Péricles teria sido o responsável pela guerra ao propor um ataque à cidade de Mégara por motivos de pouca importância. Ele o teria feito para desviar as suspeitas contra sua administração, provocadas pelo exílio a que fora condenado um de seus amigos, acusado de ter desviado o ouro destinado a uma estátua que deveria fazer a pedido da cidade.

Assim, o complexo conflito entre as potências rivais de Atenas e Esparta vê-se reduzido ao fruto dos interesses espúrios de um político, portanto potencialmente sacrificável, por exemplo, por meio do sistema de ostracismo, em que o poder da doxa se fazia sentir, visto o resultado depender de uma votação dos cidadãos. Levantar a relação da acusação com essa expulsão hipotética não me parece grande exagero, já que a acusação veiculada pelo deus se liga exatamente a um processo de ostracismo considerado justo.

Mas é na parábase da peça - componente tradicional da comédia grega em que os personagens se dirigiam mais diretamente ao público, apresentando abertamente as opiniões do autor, chegando a incomodar tanto aos políticos que foi proibida - que a percepção que tem Aristófanes do sacrificialismo de sua sociedade se manifesta de modo mais interessante. Nela, que se inicia após liberarem a Paz, que fora aprisionada pelos deuses em uma caverna para punir os gregos justamente por rechaçarem a divindade alegórica cada vez que tentava aproximar-se ${ }^{37}$, novamente se atribui as

\footnotetext{
37 Sem a intenção de superdimensionar este elemento da peça, pode ser interessante notar a semelhança desta jocosa alegoria com uma expulsão sacrificial como as narradas em diversos mitos, tendo por efeito, porém, não a pacificação de uma crise, mas sua origem. Em certos mitos, a que Girard chama de mitos de cólera de deus, o sacrifício coletivo de uma divindade ou vítima que será divinizada é visto como culpável e resulta, primeiro, em uma punição, para em seguida fundar uma nova ordem social. Indo mais longe em associações mitológicas sem buscar tirar grandes consequências disso para a peça, este fim da crise após o resgate de uma divindade feminina de uma caverna lembra o mito
} 
causas da guerra aos interesses espúrios de personagens políticas vivas ou mortas, duramente satirizadas. Utilizando uma metáfora significativa, ele compara-se os cidadãos a uma matilha canina, que se lança ferozmente e estraçalha toda vítima que estes defensores da guerra designam a eles.

Pouco depois, aparentemente o próprio autor toma a palavra em cena, e, ainda que de modo jocoso e em grande medida ridicularizando a si mesmo, apresenta sua ação de comediógrafo em termos heroicos e, em nossa chave, sacrificiais. Continuando o símile dos cães, ele afirma enfrentar corajosamente sozinho o monstro de muitas cabeças, que seria a multidão dos defensores da guerra, atacando sem medo a todos que merecem ser atacados, malgrado seu domínio sobre os cidadãos/cães ${ }^{38}$.

Em A rota antiga dos homens perversos ${ }^{39}$, Girard ressalta que muitas vezes uma coletividade assassina é comparada a um coletivo de animais grupais, como lobos ou cães, que se lançam contra uma vítima solitária. Também neste livro, ele dá bastante destaque ao fato de que frequentemente são os poderosos de uma comunidade os que se tornam suas vítimas e, continuando o raciocínio, poderíamos considerar que o preço a pagar pelo comando sobre a matilha é expor-se ao risco de, ao perdê-lo, sucumbirem a seus dentes. Aristófanes percebe essa articulação entre a matilha e seus líderes e - embora seja preciso destacar que não de modo particularmente violento em A Paz, diferente de As rãs, por exemplo -, se propõe a tomar, em parte, o lugar destes últimos e designar a eles próprios como as vítimas do bando, ainda que para isso corra, por sua vez, o perigo de ser vitimado pela comunidade.

Mas o que mais se aproxima de uma expulsão sacrificial propriamente encenada na peça é o tratamento dado ao profeta Hiérocles.

\footnotetext{
japonês de Amaterasu, em que a noite sem fim é rechaçada no momento em que as demais divindades consolam a deusa sol e a convencem a deixar o subterrâneo em que se ocultara.

${ }^{38}$ Em nota da edição utilizada, esclarece-se que há um trocadilho com o nome de uma famosa prostituta, Cina, que significa cadela. $\mathrm{O}$ autor fala dos raivosos olhares de cadela que o monstro lança contra ele, mas considerando a comparação com os cães de pouco antes, me parece claro que ele faz também alusão ao ódio que os políticos satirizados infundem em seus seguidores contra ele.

${ }^{39}$ GIRARD, René. A rota antiga dos homens perversos. São Paulo: Paulus, 2009.
} 
Tendo liberado a Paz e retornado a Atenas com a Abundância - com a qual o agricultor se casará - e a Alegria, Aegídio leva esta última divindade ao senado, não mais belicoso ${ }^{40}$ e lá prepara um sacrifício para a Paz. Enquanto o faz, o profeta se aproxima e, em tom pomposo e obscuro, faz predições contra o abandono da guerra.

Esta, que é a única voz a destoar do regozijo generalizado, comporta ao menos um estereótipo vitimário: o de ser estrangeiro. A não cidadania ateniense ou sua suposta ilegitimidade é uma das pechas que Aristófanes lança com mais frequência contra seus desafetos, por exemplo, o já mencionado Cleofonte, cuja morte pregava, sendo acusado por ele de possuir mãe estrangeira, em As rãs.

De início, Trigeu e seus escravos, dedicados à preparação da oferenda, apenas se impacientam com o profeta, zombam de suas previsões de catástrofe e dele próprio, principalmente aludindo à sua proveniência. Quando a refeição sacra está pronta, porém, não permitem que ele tome parte nela, o que deseja fazer não por fins piedosos, mas por apetite, e terminam por enxotá-lo a pauladas. Assim, temos a expulsão violenta de um estrangeiro, ao menos pretensamente ligado ao sagrado por sua condição de profeta e que é o único a quebrar a unanimidade na peça, além disso, a peripécia se dando durante um rito sacrificial.

Não convém exagerar a importância deste episódio secundário. Por outro lado, também não convém esquecer a já mencionada tendência da vida pública ateniense à expulsão efetiva ou condenação à morte daqueles que caíam em desgraça perante a opinião pública e, portanto, a proximidade dessas alegres piadas com fenômenos de maior seriedade. Também sem exagerar o peso que uma comédia podia ter nesse

\footnotetext{
${ }^{40}$ Novamente gostaria de destacar a semelhança incompleta deste ponto com fenômenos sacrificiais, mesmo sem tirar grandes consequências disso. A entrega da Alegria ao senado faz referência ao costume que a instituição política tinha de enviar comissões festivas a aliados estrangeiros antes da guerra, mas mais interessante que isso é a forma como ela se dá. $O$ agricultor pede que a deusa se dispa e a entrega à voracidade sexual dos senadores, fazendo trocadilhos acerca da variedade de práticas sexuais que poderiam manter com ela ao longo de dias como forma de comemoração pelo regresso da paz. Isso talvez não pretenda mais do que despertar na plateia a hilaridade e alegria que o autor associava com o regresso da paz que antecipava em sua ficção através do campo sexual, sempre muito presente em suas comédias, e, quem sabe, ridicularizar a suposta dignidade e contensão dos políticos da cidade; não obstante, a entrega de uma única mulher ao apetite sexual de uma coletividade de homens evoca casos de estupro coletivo, nos quais, não raro, a vítima é vista como culpada e se torna um bode expiatório. Além disso, a comemoração também se aproxima de um rito orgiástico, como os praticados em muitas culturas, em alguns destes, uma única jovem praticando o ato sexual com diversos homens e sendo sacrificada ao final.
} 
contexto, considerando sua enorme popularidade, não é equivocado considerar que aqueles que se viam ridicularizados e tinham a imagem maculada em tais peças corriam um risco relativamente mais alto de se tornarem as vítimas deste fervilhante e intenso mecanismo sacrificial que era a democracia ateniense.

\section{Enfraquecimento do coletivo na Comédia Nova}

Em uma literatura reconhecidamente menos viva, como a comédia nova grecolatina - que acompanha o declínio da possibilidade de participação política no contexto imperial macedônico ou romano, embora não se possa situar a origem da diferença inteiramente aí, visto os indícios de que a maioria das comédias contemporâneas a Aristófanes foram muito menos ambiciosas -, o elemento coletivo da doxa, a erguer e derrubar os indivíduos, desaparece. Os enredos perdem qualquer relação com as questões coletivas e passam a girar em torno de problemas individuais e familiares e, em decorrência, o elemento sacrificial torna-se bem menos visível.

Ainda assim podemos encontrar traços dele no fato de que a maior parte dos famosos tipos, que influenciaram todo o teatro cômico até o classicismo, com exceção da idade média, se encontra entre os grupos preferenciais para a escolha de bodes expiatórios: escravos, velhos, prostitutas e estrangeiros. O modo como eram ridicularizados, muitas vezes, continha bastante simpatia, mas também podia manifestar grande crueldade, por exemplo, em 0 Eunuco $^{41}$ de Terêncio, o militar estrangeiro Trasão se torna um verdadeiro bode expiatório ridículo, visto os demais personagens, incluindo o parasita Ginatão, que até então estava de seu lado, basearem o arranjo que lhes conviria em um plano para enganá-lo e fazê-lo sustentar a todos ao se crer amante da cortesã Taís, com quem um dos protagonistas seguirá mantendo suas relações amorosas ${ }^{42}$.

\footnotetext{
${ }^{41}$ TERÊNCIO. O eunuco. Em: Plauto e Terêncio/A comédia latina. Coleção Universidade. Rio de Janeiro: Edições de Ouro.

${ }^{42}$ De mistura com alguns elementos talvez, até, avançados para o contexto patriarcal romano, também há muitos elementos de enorme violência inteiramente naturalizada nestas peças, sem que os possamos considerar, em si, sacrificiais. Por exemplo, no mesmo $\mathbf{O}$ eunuco o estupro de uma escrava por um jovem rico surge como inteiramente natural; o fato de que, em realidade, ela fosse cidadã torna as coisas um pouco mais difíceis, mas, visto o rapaz estar disposto a casar-se com ela, a descoberta vem
} 


\section{Carnavalização, transformação e conservadorismo em Rabelais}

\subsection{O sacrificialismo na cultura carnavalesca}

Dando um grande salto por cima da Idade Média, vemos como na obra cômica de François Rabelais ${ }^{43}$ o elemento coletivo volta a estar presente com muito maior força. De forma alguma do mesmo modo que em Aristófanes, cuja obra reflete o perigoso jogo político da Atenas democrática, mas refletindo, por sua vez, os modos de sacrificialismo próprios à sociedade em que surgiu.

Os elementos de coletividade na obra deste autor são longamente estudados por Mikhail Bakhtin ${ }^{44}$, que o atribui com razão a seu enraizamento na tradição popular do período medieval e do Renascimento, que por sua vez apresentam continuidade direta com a cultura carnavalesca da Antiguidade. A análise do teórico russo é brilhante, mas me parece equivocada em muitos pontos, cuja discussão será fecunda para a perspectiva adotada neste trabalho. Deste modo, a análise que se segue é menos direta que as demais, passando pela mediação do diálogo com o arguto crítico.

Bakhtin vê como principal característica da obra de Rabelais a carnavalização: a inversão das hierarquias e a supressão dos tabus e prescrições da vida séria, as quais reinavam nas muitas festas carnavalescas que, desde a Antiguidade clássica, ocupavam considerável parcela do ano e que seguem existindo, embora com cada vez menor força desde a Modernidade. Em tais inversões, vê uma força libertária e transformadora, a qual incomoda e ameaça o poder estabelecido, contendo potencial revolucionário. Para ele, a visão de mundo intrínseca a tais períodos, própria às camadas populares, é ambivalente e oposta a qualquer unilateralidade, nela a morte e

\footnotetext{
mesmo a calhar e conduz a um perfeito final feliz. De outra parte, como nota Northrop Fry, a ameaça descritiva dos castigos, correntes em Roma, a que seriam submetidos os escravos é um grande elemento de comicidade, o crítico e pastor protestante comentando que isso nos faz supor que o público de Terêncio riria às gargalhadas durante toda a paixão de Cristo, coisa realmente provável, visto o escárnio ser um de seus elementos centrais.

${ }^{43}$ Disponível em áudio no endereço http://www.litteratureaudio.com/livres-audio-gratuits$\mathrm{mp} 3 / \mathrm{tag} /$ francois-rabelais

${ }^{44}$ BAKHTIN, Mikhail. A cultura popular na Idade Média e no Renascimento. São Paulo: Hucitec, 2010.
} 
a vida se revelando como complementares, visto a destruição do velho resultar no nascimento do novo e, portanto, em uma constante renovação que reflete a imortalidade da natureza e do povo enquanto coletividade. Uma visão oposta a qualquer dogmatismo, medo ou individualismo, já que nela tudo faz parte de uma totalidade em constante mutação, sendo tolice fadada ao malogro se apegar a qualquer de seus aspectos presentes, assim se tornando possível a valorização do corpóreo transitório e dos prazeres da comida, bebida e do sexo.

Aqui cabem nossas primeiras críticas às teorias de Bakhtin. O primeiro que nos ocorre é o questionamento quanto ao efetivo potencial revolucionário das festas carnavalescas. Se, de fato, as hierarquias e prescrições impostas pelas instituições detentoras do poder são suspensas durante elas, o evidente caráter temporário dessa suspensão nos faz duvidar de seu verdadeiro poder de oposição a elas e, mesmo, suspeitar que possa exercer uma função conservadora como válvula de escape - isso para evitar, por ora, o ponto principal desta crítica. Em todo caso, a eclosão recorrente desses momentos de suspensão da ordem pareceria, antes, indicar uma concepção cíclica, e portanto conservadora, da vida do que um princípio de transformação. Bakhtin prevê e rejeita essa objeção, sem, contudo argumentar convincentemente contra ela, negando, apenas, que se trate de um tempo cíclico pelo fato de se voltar para o futuro. Não obstante, é claro, poderíamos localizar argumentos que fundamentassem parcialmente essa posição na obra como um todo, ao que voltaremos.

Outro problema é que o elogio bakhtiniano da ambivalência carnavalesca e sua critica à unilateralidade do sério são bastante unilaterais. Embora isso talvez se justifique em parte por uma crítica implícita à opressão e pretensões totalitárias vigentes na sociedade do autor - que sofreu diretamente suas consequências -, a condenação lançada por ele contra qualquer instituição séria, governamental ou eclesiástica, parece excessiva, assim como (mais grave) seu elogio à cultura popular é demasiadamente idealizante. Pareceria que, apesar de afirmá-lo constantemente, o estudioso não leva realmente a sério a ligação indissociável da cultura oficial e da carnavalesca. 
Embora houvesse representantes das autoridades que de fato se opunham às festas carnavalescas em bloco e, sem sucesso, procuravam cerceá-las, a nobreza e o clero, em geral, tomavam parte nelas, sem que isso os impedisse de manter sua efetiva dominação. Em sentido contrário, embora certamente houvesse entre as camadas populares aqueles que mantinham uma atitude de hostilidade e irreverência mais constante contra as autoridades e dogmas, a maioria se entregava sinceramente ao culto oficial e mantinha um respeito por vezes entusiástico frente a seus governantes. Poderíamos dizer que, neste ponto, faltou ao pensador marxista um pouco de dialética e maior atenção à ideologia enquanto elemento discursivo e valorativo que promove a integração no interior de uma sociedade, malgrado suas tensões e conflitos internos.

Além disso, também a cultura popular abunda em preconceitos, tais como racismo, xenofobia, homofobia, machismo ${ }^{45}$ e uma enorme hostilidade contra as religiões não cristãs (já que aqui estamos nos concentrando no contexto europeu estudado por Bakhtin), particularmente a judaica e a muçulmana. Trata-se, em geral, dos mesmos bodes expiatórios coletivos assumidos pela cultura oficial, o que une ambos os segmentos culturais - para manter a divisão em si questionável, embora apoiada em muitos elementos concretos - nas mesmas tendências sacrificiais. 0 mesmo se verifica em casos mais particulares, como podemos ver na participação irreverente, alegre e, aliás, carnavalesca da população nas execuções capitais promovidas pelo poder, não apenas de nobres frustrados em tentativas de golpes políticos, mas também na de notórios fora da lei heroicizados ${ }^{46}$.

\footnotetext{
${ }^{45}$ Bakhtin reconhece uma condenação das mulheres típica da cultura popular, mas, com boa dose de razão, afirma tratar-se daquela própria à tradição saxã, muito menos negativa que a visão eclesial oficial que via a mulher como fonte do mal e instrumento de tentação. Na tradição saxã, que representa as mulheres como necessariamente infiéis e ridiculariza os maridos traídos, chegaria a haver, na verdade, uma valorização da sexualidade feminina e certo reconhecimento de sua liberdade para dispor dela segundo sua própria vontade. Entretanto, sem entrar no mérito dos problemas intrínsecos também a essa visão parcialmente mais positiva, Bakhtin, aqui, como em outros momentos, parece levar em conta apenas o discurso, ignorando a prática, ou seja, o problema mais sério da assimetria social entre homens e mulheres e a autoridade efetiva atribuída àqueles sobre estas, para não falar na violência direta a que muitas vezes eram submetidas.

46 Leia-se as descrições de Foucault em Vigiar e punir: história da violência nas prisões. Petrópolis, | Vozes, 1977._-Nelas, também é particularmente interessante para a perspectiva girardiana o caráter redentório e purificador presente nessas execuções, para as quais um importante fator era a participação dos condenados que, ao demonstrarem a aceitação das extremadas sevícias a que seriam submetidos como uma penitência, assumiam um ambíguo status de quase santidade. Isso se aproxima
} 
Quase tenderíamos a afirmar que Bakhtin fecha os olhos à violência presente na cultura popular e, em particular, no carnaval, mas isso não é inteiramente correto; o que faz é considerá-la positiva. Para ele, o escárnio, o rebaixamento humilhante e mesmo a violência física, desde que praticadas em contexto carnavalesco, não são jamais excludentes ou destruidoras. Seriam, antes, um modo de integrar seus alvos na coletividade festiva, corrigindo suas atitudes rígidas e sua pretensão à superioridade, contrárias à alegria da vida corporal. Para manter essa visão, ele dá pouca atenção à violência praticada contra os grupos vítimas de preconceito acima mencionados, destacando aquela dirigida contra os velhos, que representariam todo o apego conservador - nisso não sendo levado em conta que, para além do símbolo, os idosos estão, de fato, entre os mais indefesos frente à violência -, e os poderosos, sobretudo os monarcas.

E aqui chegamos a um ponto de particular interesse tanto para Bakhtin quanto para a teoria girardiana: o destronamento. A diferença de perspectiva nas duas abordagens, contudo, é bastante grande, a crítica que, ao assumir a teoria mimética, se impõe com relação à bakhtiniana sendo bastante evidente.

Como já abordado anteriormente neste trabalho, para Girard, as festas de transgressão, em sua origem, longe de serem momentos de ruptura com relação à ordem social estabelecida, são rituais sacrificiais que reproduzem controladamente sua catastrófica dissolução durante as crises de violência mimética e a reestabelecem por meio do sacrifício. Isso é fácil de se notar ao recuarmos ainda mais, para além da cultura clássica, onde Bakhtin detém seu exame, na reconstituição do trajeto das festas carnavalescas, notando seus paralelos com instituições de culturas tribais e outras civilizações antigas. Como também fica claro por essa comparação, a aclamação de um rei do carnaval, seu subsequente destronamento e expulsão, seriam um deslocamento do regicídio ritual, que com grande frequência encontrava-se no centro de tais festas, para vítimas substitutivas - que além de reis temporários, como é típico 
da substituição sacrificial em geral, também podiam ser animais -, permitindo, assim, que o rei reforçasse e perpetuasse o seu poder ${ }^{47}$.

O rei do carnaval era em geral um louco, com o que Bakhtin muito se alegrava, lendo esta coroação como parte essencial da inversão do alto e do baixo que tanto o agradava. Por outro lado, valorizava enormemente o destronamento que tinha lugar nas mesmas festas, considerando-o o mais significativo elemento da oposição que a cultura carnavalesca oferecia às pretensões de perfeição e eternidade do poder, não levando em consideração que o "rei" expulso e perseguido era o mesmo louco coroado, não o monarca real, ou seja, que o destronamento carnavalesco resultava em um sacrifício (não levado até às últimas consequências) de um representante das mais tradicionais vítimas da coletividade, concomitante com o reestabelecimento do poder sério do rei. Como lembra Cesáreo Bandera ao, igualmente, criticar a teoria bakhtiniana a partir da de Girard, embora fossem raros, chegou a haver, até séculos pouco remotos, casos em que tais reis dos tolos terminaram por morrer acidentalmente.

Entretanto, como mencionado, há diferenças entre aquilo que se passa nas festas carnavalescas e o que encontramos na obra de Rabelais, ainda que não discordemos do fato de que sua construção se alimenta direta e conscientemente das primeiras. Os destronamentos presentes em seus livros não são simulacros dirigidos contra vítimas substitutivas, senão a queda real (no plano ficcional) de monarcas reinantes por consequência da guerra. Assim sendo, sem perder de vista os elementos sobre os quais a consideração das festas carnavalescas lança luz, também devemos levar em conta a reflexão acerca do fenômeno real do destronamento ao buscar definir o sentido específico de sua representação na ficção de Rabelais.

Um traço relevante, para nós, do destronamento real é que, conquanto muito sério, costuma ser de fato acompanhado pelo riso. Há poucos objetos mais próprios ao escárnio e à zombaria do que um rei caído. Na tradição bíblica, por exemplo, nos dois mais importantes textos que curiosamente foram lidos como referentes à queda de

\footnotetext{
${ }^{47}$ Ao discutir o mito de Gilgamesh no primeiro capítulo, trabalhei a hipótese de que alguns de seus elementos refletiriam o momento em que tal substituição se consolidou nas sociedades sumérica e babilônica.
} 
Lúcifer, mas que em realidade se tratam de ameaças proféticas relativas à queda de reis humanos, o riso generalizado de escárnio entra em jogo. Além disso, não há receio maior para um soberano do que o de ser exposto à plebe zombeteira após uma derrota militar; processo em que, ao mesmo tempo, a glória e o poder do vencedor são alimentados, demonstrando como também fora do âmbito ritual o destronamento não significa um golpe contra o poder, mas sim sua transferência e reafirmação.

Quanto a isso, em verdade, não há problema em si, pois, a despeito de algumas incoerências, Bakhtin não é anarquista, mas defensor da transformação através da revolução ${ }^{48}$. Como os melhores marxistas, ele não condena em bloco o passado, mas faz distinções entre correntes que representavam avanços à sua época, não sendo, por exemplo, avesso à realeza como um todo e considerando certos monarcas como representantes do que havia de melhor em seu contexto histórico. Tais monarcas seriam, para ele, justamente os que menos se afastam da concepção de mundo da cultura popular e da festa carnavalesca, delas se alimentando.

Eis um dos argumentos não explicitados que poderíamos localizar no trabalho de Bakhtin contra a inscrição da cultura carnavalesca em um tempo cíclico. Em realidade, ela não se restringe aos períodos de festa, mas estende-se, no dia a dia, paralela à cultura oficial naquilo que Bakhtin chama "linguagem da praça pública", licenciosa e irreverente frente ao poder e à religião, presente nas feiras, entre os estudantes, entre o clero e mesmo na nobreza e na realeza. Unindo isto à evidência de que a mudança é real, por mais que no passado possa ter sido lenta para padrões atuais, não seria impossível localizar nesses elementos da cultura popular o fator que carregaria suas sementes.

Mas ainda cabem algumas objeções. A primeira é a de que, como se vê, o riso carnavalesco zombeteiro não é necessariamente o motor do destronamento real, que via de regra é levado a cabo por um concorrente já elevado no jogo do poder. Há, claro - mas não em Rabelais -, casos de revolta popular sem ligação com representantes do poder já estabelecido, as quais, mais frequentemente, possuem êxito temporário, de um modo ou de outro sempre engendrando novos detentores do poder. Mesmo

\footnotetext{
${ }^{48}$ Por ora não discutiremos o difícil problema de se, e até que ponto, a violência revolucionária se justifica, pois o último capítulo desta dissertação se dedicará a ele.
} 
nesses casos, embora o riso certamente acompanhe sua vitória, cabe perguntar o quão grande será a proporção de sua participação, ao lado de tendências mais claramente agressivas, nos motivos que impulsionam o combate.

O riso acompanha o destronamento, mas de modo incidental, coroando, por assim dizer, os vencedores, sejam quais forem as tendências que representam. Assim, pode ressoar tanto na queda de um verdadeiro opressor, quanto, por exemplo, na humilhação dos condutores de um povo recém-assimilado ao Império Romano, ou, ainda, durante a crucifixão dos escravos rebelados. Ou seja, mesmo que alguns dos melhores soberanos possam, talvez, terem apresentado uma maior ligação com a cultura carnavalesca, será que podemos considerá-lo um traço distintivo qualitativo, dado o fato de seu riso não parecer fazer distinção entre suas vítimas, exceto ao dar preferência às que se encontram por baixo?

Em suma, o que procurei demonstrar é que, menos do que um elemento de transformação social ou mesmo de contraponto aos excessos do poder, a cultura carnavalesca se liga à violência sacrificial que estrutura toda sociedade, sendo neutra do ponto de vista avanço versus conservadorismo social, se assim podemos nos expressar. Entretanto, acredito que na obra de Rabelais, como em outras manifestações da cultura popular, encontram-se realmente muitas das características positivas que Bakhtin atribui a tal cultura como um todo. Isso não se dá, porém, sem ambiguidades, inclusive a posição do autor passando por uma mudança vantajosa do primeiro para o segundo de seus livros segundo a ordem de publicação, Pantagruel sendo mais sacrificial que Gargantua.

Passaremos agora à interpretação de partes da obra rabelaisiana, lembrando que, aqui, não há a intenção de discutir o cômico como um todo, mas apenas seus elementos mais diretamente ligados ao sacrificial.

\subsection{O sacrifício na ficção de Rabelais}

Os protagonistas de Rabelais, Gargantua, no segundo de seus cinco livros, e seu filho Pantagruel, nos outros quatro, são príncipes guerreiros, uma posição social entre as mais típicas para heróis épicos. Não obstante, são também gigantes monstruosos, 
dados à mais irreal glutonaria e abuso do álcool. Como já discutimos, características monstruosas e excessos que na vida social cotidiana e na literatura séria seriam considerados condenáveis estão, quase sempre, presentes nos heróis sacrificiais, fazendo-se mais visíveis e se apresentando sob luz positiva na literatura cômica; o que, segundo a interpretação aqui adotada, deriva de características culpáveis atribuídas a vítimas reais na base da tradição mitológica.

Mas os gigantes de Rabelais não são apenas duplos cômicos de heróis épicos, aliás, a caracterização que fiz deles como príncipes guerreiros, embora verdadeira, sendo um tanto excessiva, visto não ser esse seu aspecto mais destacado durante a maior parte da obra. Eles são, também, duplos cômicos do que o autor certamente considerava o mais avançado e louvável em sua época, soberanos absolutos esclarecidos e, como ele próprio, eruditos humanistas. Esse é um ponto importante, que nos obriga a ter em mente a rejeição de Bakhtin às interpretações que procuram ver na obra de Rabelais uma sátira crítica a tudo que se encontra nela representado. Mas certamente há atitudes e personagens que o autor condena, e esses são, justamente, os que são ridicularizados no plano intrínseco à obra, em que as atitudes cômicas ou grotescas dos personagens positivos aparecem como naturais ou mesmo louváveis.

O modo como se dá a ridicularização desses personagens, parece-me, sofre uma alteração do primeiro livro para os que se seguem, nesses se aproximando mais do ideal reconhecido por Bakhtin de corretivo que rebaixa aos demasiado orgulhosos para situá-los no mesmo nível que a comunidade unida na alegria própria à festa, cujas tendências igualitárias podem ser vistas como um ideal. No primeiro livro, porém, a ridicularização é mais destrutiva e mais propriamente sacrificial, embora esse elemento não esteja inteiramente ausente dos demais.

Um bom exemplo desse riso corretivo e benigno encontra-se em uma cena analisada por Bakhtin nessa chave. Nela, um erudito "sorbonita" é designado para, servindo-se de sua retórica, convencer Gargantua a devolver o sino de uma catedral, do qual se apropriara para pendurá-lo ao pescoço de sua jumenta gigante. 0 protagonista devolve o objeto antes mesmo que o emissário possa fazer seu discurso, 
então permite que o profira inutilmente, atraindo sobre si as risadas de toda a audiência, mais bem informada do que ele. Quando conclui e se inteira da humilhação a que foi submetido, o professor se envergonha, mas não leva a mal a brincadeira, toma parte na hilaridade geral e reconhece ser tempo de se aposentar, contentandose em passar o resto de sua vida com os simples prazeres de uma lareira junto à qual se aquecer e uma tigela de sopa de que se alimentar.

O episódio apresenta uma estrutura sacrificial, visto nos depararmos com uma vítima única, ao redor da qual se congrega uma unanimidade que a hostiliza. Entretanto, não conviria levar tal ficção demasiadamente a sério - embora não custe ressaltar que, no mundo real, semelhante humilhação poderia ter consequências trágicas - e seu desfecho é, mesmo, simpático para com a vítima. Neste trecho, Rabelais faz uma acerba crítica às pretensões exclusivistas e arrogantes do meio universitário - que contava mesmo com poderes de censura - ao saber, mas não demonstra uma verve particularmente cruel ou vingativa.

Já um personagem que, mesmo após o primeiro livro, tende a associar-se a um senso de humor bastante mais cruel é Panurge. Ele é o que mais se aproxima do típico trickster lendário e mitológico, um astuto personagem que, em geral apenas por brincadeira, se mostra um elemento de desestruturação da ordem capaz de conduzir a verdadeiras convulsões sociais, muitas vezes se tornando o bode expiatório da crise provocada.

Pantagruel se depara com Panurge por acaso em uma das viagens que empreendia em seu período de formação. O insólito personagem, faminto e de aparência miserável - após procurar fazer contato em diversas línguas, reais ou inventadas, antes de fazer recurso ao francês que via seus interlocutores empregar -, torna-se um dos mais próximos companheiros do príncipe e logo lhe narra uma de suas aventuras pregressas, na qual sua virtude de produzir o caos fica patente.

Nessa mirabolante peripécia, contada em meio a uma grande bebedeira, sob jura de não faltar com a verdade - o que colocaria sua realidade em dúvida, não fosse a falta de verossimilhança que apresenta se coadunar perfeitamente com a lógica do livro -, Panurge fora feito prisioneiro pelos turcos, contra a religião dos quais lança 
vários impropérios durante a narrativa e que caracteriza como canibais e invocadores de demônios, embora, com a característica contradição própria ao tom do livro, também se demonstrem bastante cordatos e prestimosos. Um deles põe-se a assá-lo vivo, atado a um espeto, no interior da própria casa. O herói cristão remete a própria situação - preso entre os infiéis e condenado ao fogo - ao martírio de São Lourenço, levado às chamas pelo imperador romano Valeriano. Assim, o próprio personagem se compara a uma vítima sacrificial santificada, em torno da qual os cristãos organizam o próprio sacrificialismo voltado contra os não $\operatorname{cristãos}^{49}$.

Seu carrasco adormecendo, Panurge - que o atribui à intervenção de Deus ou, talvez, de Mercúrio (outro célebre trickster) - consegue atear fogo à casa, aproveitando-se disso para fugir e matar o turco que o seviciava. No meio tempo, os habitantes da cidade em que isso se dava acorreram para combater o fogo, mas, distraindo-se com Panurge, que tinha o corpo meio queimado, permitem que o incêndio se alastre e tome as duas mil casas que a compõem. Deste modo, na sequência de um sacrifício mal sucedido - e condenável, por-quanto praticado pelos maometanos, cuja fé o narrador atacara diversas vezes, embora por motivos cômicos , o futuro companheiro de Pantagruel, que seria sua vítima, leva toda a comunidade que o praticaria a perecer, o que podemos ver como uma justa punição - embora complicada pela afabilidade com que os turcos o trataram ao vê-lo escapar às chamas -, tanto mais pela comparação, feita pelo personagem, da cidade com Sodoma e Gomorra.

Antes de abandonar o episódio, ainda vale ressaltar que, enquanto se ria da desgraça que provocara, Panurge se vê exposto a novo risco com elementos sacrificiais, que mais tarde também voltará contra seus inimigos, como acabava de fazer com o fogo. Mais de seiscentos cães, fugindo do incêndio, são atraídos pelo cheiro da carne queimada de Panurge, e o teriam estraçalhado caso este não os distraísse ao jogar-lhes pedaços de carne, pelos quais disputam às mordidas.

Lembrando mais uma vez a leitura feita por Girard de grupos de predadores como metáfora da coletividade sacrificial, podemos considerar que, mesmo sem que

\footnotetext{
${ }^{49}$ Um interessante exemplo disso é O auto de São Lourenço, de José de Anchieta, que analisei sob esta perspectiva em meu trabalho "Um auto sacrificial".
} 
Rabelais o tivesse em mente, as ameaças contíguas do martírio entre os turcos e a da dilaceração pelos cães apresentam um significativo espelhismo, no qual os animais e os maometanos carregam, cada um, elementos distintos da crise mimética. $\mathrm{Na}$ comunidade turca, em princípio, parece reinar a mais pura paz, não havendo disputa entre eles, nem agressividade contra o estrangeiro, exceto no caso do paxá que pretendia comê-lo e um outro cidadão que, inocentemente, tentou provar de sua carne após sua fuga. Ainda assim, sua presença provoca uma perigosa suspensão da ordem, e não inteiramente desprovida da mímesis de apropriação que dá origem às rivalidades, já que todos na cidade, desde seus governantes, acorrem na intenção dupla de combater o fogo e se apropriar das riquezas da casa incendiada. Em seguida passam a se preocupar apenas com o estrangeiro, mas é essa distração inicial que permite a propagação do incêndio, que Girard vê nos mitos, assim como a peste e outras catástrofes naturais, como uma substituição da crise de rivalidade mimética, a qual a representa bastante bem, pois o fogo se alastra de casa em casa, assim como a má reciprocidade passa de um indivíduo a outro por contato, até englobar toda a comunidade.

Já entre os cães, cuja fuga é resultado da primeira crise, a agressividade contra a vítima única que seria Panurge está dada, mas não se realiza, degenerando em disputas internas pela posse de um objeto de desejo: a carne que o astuto personagem Ihes atira. Assim, neste que poderíamos ver como uma espécie de mito da origem do herói Panurge, há a oposição entre ele, singularizado, e uma coletividade hostil, no seio da qual provoca a crise no momento em que falham em vitimá-lo. Posteriormente, ele atuará em mais de uma ocasião como articulador do sacrifício de outros, para isso utilizando, por vezes, coletividades animais, assim como personagens míticos frequentemente passam a ter como um de seus atributos aquilo que os vitimou. Deste modo, mais à frente, se vingará de uma nobre que rejeitou suas investidas amorosas espalhando o sexo picado de uma cadela no cio em suas roupas, atraindo uma multidão canina que a persegue por toda a cidade à vista de todos, e no terceiro livro se vinga de um negociante de carneiros que tentara cobrar-lhe um preço abusivo ao jogar o animal que adquirira dele do parapeito de um navio, fazendo com que todo o rebanho o siga e arraste consigo o proprietário para a morte. 
Mas qual o papel deste trickster na obra de Rabelais? Principalmente, claro, contribuir para a comicidade pura que decorre do encadeamento de eventos que conduzem a um distúrbio cada vez maior da ordem. Sem, necessariamente, elementos sacrificiais, o caos crescente provocado, com maior ou menor inocência, por um personagem introduzido a um ambiente em que não se encaixa e no qual seu deslocamento envolve um número crescente de pessoas é um dos recursos cômicos mais utilizados, por exemplo, em filmes ou desenhos animados, o qual podemos supor, evoluiu a partir de mitos e lendas de trickster. Boa parte da comicidade de clássicos como Don Quijote ou Macunaíma (trickster por excelência) reside nesse recurso ${ }^{50}$.

Mas acredito haver mais. Embora sem qualquer status divino, Panurge se aproxima verdadeiramente de alguns dos exemplos mais espetaculares de trickster, como Dioniso ou Exu, cujos caprichos e a suscetibilidade vingativa não raro conduzem a desmembramentos e decapitações, por vezes de monarcas.

No caso de Dioniso, é fácil se recordar do mito de Penteu, em que a chegada do deus à cidade de Tebas provoca crescente desordem, culminando com o dilaceramento do rei. Em um episódio com maiores semelhanças à estória de Panurge que acabamos de estudar, narrado no hino homérico em sua homenagem, a divindade, recém-nascida, termina a bordo de um navio, onde é ameaçada pela tripulação, a qual converte em golfinhos, ou seja, a coletividade que tenta vitimá-lo não o consegue e termina sucumbindo. Quanto a Exu, veja-se o mito discutido por José Jorge de Morais Zacharias no livro Alma brasileira ${ }^{51}$, em que a vingança do orixá por ofensas não tão graves culmina na decapitação do monarca de um reino africano.

Como nota Girard, fazer de Dioniso o deus do vinho é uma atenuação de seu verdadeiro atributo, claro em seus mitos e ritos, em que se liga ao transe coletivo e sacrificial, estado que caracteriza as festas carnavalescas originais. Já Exu,

\footnotetext{
${ }^{50}$ Em suas reflexões acerca do Fidalgo da Mancha em Mentiras românticas e verdade romanesca, Girard destaca sua virtude de atrair a sensatez a seu redor para a própria loucura à luz do mimetismo embora ainda não houvesse desenvolvido esta terminologia - e em um ensaio sobre o riso, "Um equilíbrio perigoso: ensaio de interpretação do cômico" em: A voz desconhecida do real: uma teoria dos mitos arcaicos e modernos. Lisboa: Instituto Piaget, ele propõe que o fato de rirmos se deve ao alívio do observador distanciado por estar, ou se julgar, livre do risco de envolvimento na má reciprocidade que arrasta a todos que dela se aproximam.

${ }^{51}$ BOECHAT, Walter (org.). A Alma brasileira: luz e sombra. Petrópolis, RJ: Vozes, 2014.
} 
significativamente, é, nas religiões afro-brasileiras, o responsável pelos sacrifícios e oferendas às demais entidades, dos quais sempre recebe uma parte.

Panurge seria assim, provavelmente de modo não intencional, o personagem de Rabelais que encarna mais claramente a ligação entre a suspensão da ordem no carnaval e o sacrificialismo. Nesse sentido, é interessante - considerando que o destronamento seria a forma principal assumida pelo sacrifício no carnaval europeu que, embora não protagonize o destronamento do rei Anarche, seja ele quem assume a responsabilidade por seu destino, colocando-o em uma posição particularmente humilhante.

Voltaremos a isso em breve, mas antes é preciso tratar da parte do romance destinada à guerra.

Veremos que nesta "carnavalização" da literatura épica, alguns dos problemas típicos de sua versão séria estarão presentes. O mais importante é a apresentação da guerra como um mal necessário, imposto pelos que serão vencidos e aceito com pesar pelos protagonistas que ao fim triunfarão.

Os motivos da guerra no primeiro livro de Rabelais são bastante simples, e a justiça não poderia estar mais claramente do lado dos heróis. O rei Anarche, ouvindo que o rei Gargantua fora "transportado para o país das fadas" 52 , se aproveita do momento para, por cobiça, invadir o país vizinho e fazer cerco a uma de suas cidades.

Tendo notícia do fato, Pantagruel interrompe sua estadia na França e parte para proteger o reino paterno. Sua posição é inquestionável em termos da ideologia de "guerra justa", e assim Rabelais poderá se divertir despreocupadamente ao parodiar a literatura épica sem comprometer a simpatia de seus personagens. Nessa brincadeira, porém, muitas questões relativas à guerra em si se colocarão, algumas das quais o autor se esforçará para tratar com maior seriedade, embora sem abandonar o cômico, a partir de Gargantua, sem superar por completo seus paradoxos.

\footnotetext{
${ }^{52}$ Este é, claro, um eufemismo para indicar a sua morte. Ainda assim, no contexto de uma obra fantástica como esta, a realidade disfarçada pela expressão linguística e a sua literalidade se mantêm a um só tempo, bem como em Macunaíma o "virar estrela" é literal, mas indica claramente a ideia de morte.
} 
Na primeira batalha que o príncipe gigante e seus companheiros enfrentam, tão logo desembarcam, são atacados por seiscentos cavaleiros adversários, que Panurge astuciosamente líquida com uma explosão de pólvora.

Para comemorar a vitória, os heróis farão um banquete, no qual consumirão um grande número de animais selvagens abatidos para a ocasião, utilizando-se para isso do equipamento dos vencidos como utensílios de cozinha e do fogo que os consumiu para assar as carnes. Sem levar a sério o pequeno massacre que acabam de perpetrar - bastante pequeno para o padrão de cifras astronômicas próprio a Rabelais -, os heróis têm uma festa na qual suas vítimas alimentam literalmente o fogo. Com um pequeno exagero, poderíamos quase dizer que se trata de um festim canibal.

Não gostaria de retomar a polêmica com Bakhtin, mas mais uma vez será interessante considerar uma de suas perspicazes análises, tomando-a em chave menos positiva. Penso na aproximação feita por ele entre a matança de animais, o desmembramento humano, o banquete e a guerra.

Os banquetes ocidentais têm sempre as carnes como prato principal. Assim, que tenham origem na matança, desmembramento e evisceração de animais é bem claro. Bakhtin destaca, porém, que para a cultura popular, essa matança não é uma precondição irrelevante e mantida à parte do consumo festivo do alimento, mas já se dá no espírito da festa e é constantemente recordada durante ela.

De nosso lado, podemos lembrar que em muitas culturas - e entre elas as que mais influenciaram a ocidental, como a greco-romana, a judaica e a muçulmana - todo abate de animais para o consumo de carne deve seguir rigorosas prescrições rituais, sendo, assim, propriamente sacrificial. Ainda, a tese girardiana de que o sacrifício animal (no contexto de rituais propriamente ditos) é um sacrifício substitutivo em que a violência que se abate sobre a besta é a que originalmente deveria se abater sobre um membro humano da comunidade e que, ainda antes, provocava a crise coletiva, pode nos levar a ver na matança festiva para os banquetes um traço dessa transferência de violência coletiva. Além disso, a proibição do consumo de carne na quaresma, que se segue imediatamente aos excessos do carnaval, deve-se a uma associação direta entre o derramamento do sangue animal e o sacrifício de Cristo, 
indicando que o espírito carnavalesco não é inteiramente alheio a uma associação entre a violência dirigida contra o animal e aquela dirigida contra o humano, embora a tome sob uma luz alegre e positiva.

Bakhtin não nega essa relação, e faz algumas associações que, se partissem de mim, consideraria excessivas, por exemplo, aproximando o desmembramento dos animais e a enumeração das partes espancadas do corpo de um indivíduo ${ }^{53}$. Para ele, o caráter revolucionário dessas cenas reside na abolição da ordem hierárquica do corpo humano, que era uma das principais metáforas para a ordem social na cultura da modernidade.

O filólogo faz, também, uma associação, talvez mais convincente, entre a matança e a guerra, já que em ambas há o derramamento de sangue de diversas vítimas. Mais importante do que essa multiplicidade de vítimas, porém, é o fato de que a vitória na batalha é celebrada com um banquete, que assim tem em sua base a morte dos animais abatidos e dos inimigos vencidos.

Como de costume, Bakhtin não leva muito a sério a violência que reconhece, parecendo considerar que não é de grande importância, desde que nos disponhamos a rir dela. Que as tragédias da guerra terminem no alegre consumo de carne e vinho por parte dos vencedores que se reafirmam em seu poder, é claro -, faz com que ela seja, na verdade, um evento bastante agradável.

Não se deve ver estas considerações de minha parte como uma crítica excessivamente rigorosa contra a obra de Rabelais. A ironia se dirige, antes, à não diferenciação feita por Bakhtin entre o tom da obra de Rabelais e as realidades extra literárias com que ele próprio a relaciona. Na ficção, estas, de fato, são alegres e cômicas, no que podemos, inclusive, ver sim uma tentativa de livrar o ser humano do medo e da tristeza diante da face mais cruel da realidade, como muitos autores acreditam ser a função principal do humor. Nesse caso, porém, não se deve partir da

\footnotetext{
${ }^{53}$ Ele se detém longamente na análise de um episódio em que se simula uma festa de casamento, durante a qual, segundo os costumes da região em questão, os convivas trocam pancadas entre si. $\mathrm{O}$ fim disso era surrar violentamente os enviados dos credores do organizador das fraudes, para assim impedilos de cumprir sua missão. É interessante notar a transferência de uma violência coletiva para uma vítima única que se dá nessa cena, repetida diversas vezes.
} 
liberdade de espírito face ao sofrimento para desconsiderá-lo e muito menos do otimismo com relação ao futuro para desconsiderar o sofrimento presente. A morte do velho não deve ser vista como inteiramente positiva por permitir o nascimento do novo ou então se tornará um sacrifício no pior sentido ${ }^{54}$.

Após essa primeira vitória - marcada pela criação de dois monumentos, um à vitória militar, outro ao banquete - Pantagruel e seus companheiros passam por mais algumas peripécias, nas quais o aspecto monstruoso do gigante, que provoca catástrofes intencionais ou não com os mais simples atos, volta a se manifestar, como na França, mas agora de modo mais construtivo, por acarretarem a desgraça dos inimigos. Por exemplo, assim como Gargantua inundara Paris com urina por brincadeira, dando o nome à cidade (Par rire), durante a campanha Pantagruel inunda o acampamento dos dipisodos, lançando-os no pânico. A guerra se definirá, porém, com uma batalha que, embora de grandes proporções, é decidida pelo confronto entre o príncipe guerreiro e o comandante do exército inimigo, o também gigante Loup Garou (Lobisomem).

A luta é dura, mas após derrotar o capitão inimigo, Pantagruel usa seu corpo como arma e vence os trezentos gigantes que comandava, e que tentam socorrer o chefe em apuros. Relevante, porém, é que antes de iniciar o duelo, o protagonista ora a Deus, prometendo praticar, caso vença, boas obras religiosas em seu país e em todos os territórios em que venha a exercer poder. O herói demonstra, assim, intenções colonialistas justificadas enquanto obra de fé, cujo caráter sacrificial já estudamos no primeiro capítulo. Uma voz vem do céu e confirma que Pantagruel será vitorioso, o que confere legitimidade sobrenatural a seu triunfo.

Efetivamente, a invasão malograda dos dipisodos justifica sua colonização subsequente. Pantagruel conduz, então, um exército para a conquista do seu país, não por necessitar de auxílio para submeter pela força o país vizinho, mas para diminuir o excesso de habitantes na cidade liberta, da qual provém exclusivamente o exército

\footnotetext{
${ }^{54}$ Essa tendência de Bakhtin talvez possa ser relacionada com o pior lado da dialética hegeliana, que, entretanto, não se reduz a ele: a tendência a justificar todo o mal enquanto momento necessário para a síntese sempre superior rumo à reconciliação final. As piores tendências marxistas - entre as quais certamente não incluo Bakhtin - assumem essa visão de modo muito mais grosseiro e extremamente sacrificial.
} 
extremamente numeroso para padrões da época. Este é o fim - entremeado por muitos episódios secundários amplamente desenvolvidos - de Pantagruel, no qual não parece haver o menor questionamento quanto à justiça de se submeter militarmente um país que tenha iniciado um conflito, seja por ser esta a posição do autor, seja por este não levar demasiadamente a sério o problema em seu primeiro livro.

Entretanto, essa reafirmação e ampliação do poder do soberano considerado legítimo me parece ser mais do que uma consequência despreocupada do desenvolvimento do enredo. Um indício disso é o nome do rei vencido, Anarche, que, como se vê, representa em si o oposto do ideal hierárquico que constituía a base do pensamento político medieval. Nela, o soberano deve ser a arché, sobre a qual se fundamenta a hierarquia social; quando não é capaz de cumprir esse papel, a anarquia se instaura.

Assim, longe de representar o ideal anti-hierárquico e de transformação social que Bakhtin vê nele, o destronamento de Anarche - embora construído segundo o modelo de irreverência e nonsense da obra - parece visar justamente o oposto, um fortalecimento da ordem e sua expansão por meio do colonialismo que começava a se ampliar à época do livro. Após a derrota de seus gigantes, ele é capturado e deposto, embora nem se dê muito destaque a isso. Panurge se encarrega de dar-lhe destino e faz dele um vendedor de caldo verde, casando-o com uma mulher feia e violenta, que o espanca e humilha.

A justificativa para isto é acostumá-lo com seu futuro estado no pós-vida, pois Epstemon, outro dos companheiros de Pantagruel, fora morto em uma das batalhas e trazido de volta pelo mesmo Panurge, narrando que no outro mundo os poderosos deste eram punidos ao serem forçados a ganhar a vida com profissões humildes. Já Diógenes, por exemplo, fora recompensado por sua vida de desapego, gozando do luxo e tiranizando os poderosos rebaixados. A tendência é interpretar essa inversão da hierarquia social, igualmente presente nas saturnais e no carnaval, como um golpe contra ela, mas acredito que não há um rompimento com sua lógica. O poder e o luxo continuam a ser vistos como um bem, embora devam ser utilizados segundo um ideal de justiça. Anarche é o mau rei, que não sabe manter a ordem, e por isso deve ser 
humilhado e exposto ao escárnio de todos, permitindo assim que o bom e simpático príncipe Pantagruel estenda a ordem mantida por seu sábio pai, ampliando seu poder.

Em Gargantua, a dimensão política da guerra recebe um tratamento bastante mais complexo. O motivo para isso é, talvez, a aproximação do autor com o importante homem político Guillaume du Bellay, que segundo Bakhtin se deu no período entre a escrita dos dois primeiros livros. As teorias e a prática desse estadista, que julgava necessário dispensar o tratamento mais humano e justo possível às populações de territórios conquistados em decorrência da guerra, teriam influenciado muito Rabelais, provavelmente sendo também devido a isso que logo no início do terceiro livro, que retoma a conquista da Dipisódia, essa não se apresenta mais simplesmente em termos de um colonialismo sem problemas de consciência, e é reapresentada segundo essa ótica; o que não deixa de reforçar seu elemento de racionalização ideológica.

Em Gargantua, o ideal de guerra justa se mantém, mas, com sua costumeira leveza e bom humor, o texto traz elementos que destacam suas dificuldades e contradições.

O conflito se inicia com um corriqueiro desentendimento entre um grupo de estivadores de Utopia e um de fogaceiros de um país vizinho. Na narrativa, a boa fé e inocência dos súditos de Gargantua se apresentam com uma singeleza que lembra a explicação de uma criança de como "foi ele quem começou".

Em uma pausa de seu trabalho duro, os camponeses viram os fogaceiros, que oportunamente passavam com sua carga, e muito cordatos pediram para adquirir, a preço justo, o alimento que viria bem a calhar para seu almoço. A resposta dos fogaceiros foi extremamente agressiva e arrogante, com seu líder afirmando que não eram dignos do alimento. Ainda assim, os bons trabalhadores mantêm a calma e fazem o melhor para levar tudo a bom termo. Quando isso se mostrou impossível, aquele que servira de porta-voz dos solicitantes se levanta, golpeia com um pau a cabeça do fogaceiro que os insultava e, serenamente, leva as fogaças para os companheiros, não sem pagar por elas. Os fogaceiros vão a seu rei, Picrochole, e lhe contam o ocorrido de forma distorcida, jogando a culpa nos habitantes de Utopia e fazendo com que o 
monarca se sinta desrespeitado. Assim, seguindo o mau conselho dos mais influentes nobres de sua corte, Picrochole exige reparação por meio da guerra, intencionando tomar o reino de seu vizinho. O pai de Gargantua, Grangougsier, que então reinava, por seu lado, humildemente faz o que pode para resolver a disputa diplomaticamente, mesmo cedendo em seus direitos, mas nada alcança, vendo-se obrigado a defender-se pelas armas, para esse fim chamando seu filho de volta de sua viagem de estudos em França.

Como se vê, a guerra justa se configura no enredo, já que toda a agressividade parte dos vizinhos, mais uma vez permitindo que os protagonistas mantenham sua simpatia e seu caráter positivo. Entretanto, a dinâmica do conflito se mostra como uma verdadeira escalada da violência, em que a má reciprocidade faz que a reação de cada lado à violência do inimigo seja mais drástica, ainda que os protagonistas pareçam comicamente inocentes no processo: a violência verbal recebe a violência física como resposta, esta é respondida com a invasão bélica, que exigirá a palavra final da destruição dos exércitos inimigos.

A simetria nesta má reciprocidade se evidência pelo fato de Picrochole agir na crença de que a disputa foi iniciada por seu inimigo, e é difícil tirar-lhe por completo a razão, visto a desproporção entre os insultos de um lado e a paulada do outro. Assim, como Girard mostra ser o caso em todo conflito mimético, este se inicia com o desejo de um pela posse do outro: as fogaças. O objeto da disputa logo perde o interesse, que passa a situar-se nela mesma, e, sendo impossível afirmar qual lado deu início à rivalidade, ambos acreditam com boas razões estar em seu direito.

Rabelais nos oferece uma paródia cômica das relações de poder entre os reinos europeus, a qual se encaixa modelarmente na teoria girardiana. A narrativa faz com que nos identifiquemos com um dos lados e lhe dá razão, mas revelando tão bem a dinâmica do conflito que essa tomada de partido mais parece uma ironia contra a tendência que sempre temos de ver a nós mesmos como livres de qualquer responsabilidade nos conflitos em que nos envolvemos.

Ainda assim, a ideologia da guerra justa se mantém, e se há paródia, essa não é uma paródia contra ela. Parece certo que a atitude de Grangougsier - que além de 
seus esforços pela paz passa todo o período da guerra a rezar por seu fim - é cômica por seu excesso irreal de pureza, mas que nem por isso deveria deixar de ser tomada como modelo ideal. O mesmo vale para a atitude benevolente de Gargantua uma vez vencedor.

A desproporção entre as forças do príncipe e seus companheiros e a dos invasores faz com que estes últimos sejam facilmente desbaratados. Uma vez sua completa sua derrocada, vemos a diferença no tratamento do tema do destronamento em ambos os livros. Longe de tirar o reino de Picrochole e condená-lo a uma posição humilhante, Gargantua o procura para restabelecê-lo em seu trono e, sem encontrá-lo, garante que seu filho o herde. O príncipe é piedoso para com os fogaceiros e os maus conselheiros, responsáveis pela guerra, punindo-os apenas ao obrigá-los a exercer trabalho braçal na gráfica que acaba de instaurar - ou seja, para os nobres, um rebaixamento humilhante, mas bastante moderado - e garante que o país vizinho siga governado por seus nativos, apenas estabelecendo Ponocrates como tutor do filho de Picrochole, ainda criança, deste modo garantindo a ele uma educação igual a que recebeu.

Picrochole, enquanto isso, ao ver-se vencido, foge para evitar o mau tratamento que espera dos adversários, perde seu cavalo, é espancado e roubado, recebe uma profecia segundo a qual um estranho sinal precederá seu reentronamento e passa o resto da vida a aguardá-lo, reduzido a uma humilde profissão. Ou seja, o destino que Rabelais deu a seu personagem é muito próximo do que dera a Anarche, pois o mau rei não poderia permanecer sem punição. Entretanto, ao tomar mais a sério as questões políticas implícitas no tema, Rabelais se sentiria incomodado fazendo de seus heróis os agentes dessa vingança e faz com que ela se deva à própria arrogância do vilão.

Este é um procedimento bastante comum na literatura posterior e, particularmente, em parte da indústria cultural, que reconhecendo um problema ético na resolução das tramas pela simples violência dos heróis contra seus inimigos, frequentemente busca resolvê-lo ao fazer do vilão o responsável pela própria morte, seja por orgulho, preferindo perecer a aceitar a derrota, seja por reconhecer os 
próprios erros. Este é um reconhecimento do problema ético do sacrificialismo, mas que não consegue superá-lo literariamente e, neste plano, torna-o mais completo, pois, como nos mitos mais plenamente sacrificiais, apresenta a vítima como culpada e exime por completo aqueles com quem o público deve identificar-se da violência contra o bode expiatório que oferecem a ele.

Reforçando: esta é uma evolução quanto ao sacrificialismo, pois este deixa de ser aceito sem questionamento, e a benevolência de Gargantua é bastante superior ao colonialismo despreocupado - antes de sua correção no terceiro livro - de Pantagruel. Apenas este sacrificialismo não é superado e, mais uma vez, do ponto de vista político, segue servindo menos a um ataque ao poder que a um reforço do absolutismo, sendo os desvios em seu interior que se pune pelo escárnio. Destronamos o mau rei Picrochole, que, sem a sabedoria para governar seu país e servir de base para a hierarquia se deixa levar por maus conselheiros e provoca uma derrocada da ordem, e o substituímos por seu filho, que, sob a tutela de um homem de confiança do sábio Gargantua, certamente se tornará um déspota esclarecido tão apto a manter a ordem quanto nossos simpáticos gigantes. 


\section{3 - Repressão, revolução e sacrifício}

\subsection{O sacrifício repressivo e o revolucionário}

Nos voltaremos, agora, ao exame do elemento sacrificial na representação literária do Estado moderno repressivo e dos movimentos revolucionários que buscam derrubá-lo e instaurar um modelo alternativo de sociedade. Para isso nos concentraremos na literatura dos séculos XIX e XX. Curiosamente, nesse período, em que a separação entre o religioso e a sociedade laica se consolida, é que passa a haver uma utilização mais constante de imagens e vocabulário religiosos e propriamente sacrificiais como metáfora visando destacar e criticar dados aspectos de realidades não religiosas.

Tanto os críticos da sociedade capitalista a condenam comparando-a à religião (que mais comumente vêm em si como perversa), quanto os críticos dos movimentos revolucionários os depreciam ao comparar seu entusiasmo e ideais com uma forma inconsciente de fanatismo religioso desviado de cunho messiânico (mais comumente vendo a religião propriamente dita como positiva e como um instrumento de preservação da ordem social). Provavelmente isso se deve a que a possibilidade de se distanciar do religioso, onipresente até a modernidade, permite perceber seus aspectos mais negativos e reconhecer a similaridade de suas estruturas com as dos aspectos mais negativos de realidades não religiosas. Não apenas o distanciamento é claro, mas também os ataques cada vez mais frequentes à religião, que tornaram tão claros seus aspectos nefastos - muitas vezes reduzindo-a a eles - e os converteram em um paradigma negativo modelar, fornecendo um repertório cômodo de comparações para desabonar os adversários. Mas esse mesmo distanciamento e criticismo permitiram o surgimento de linhas de pensamento que, mantendo-se ligadas à religião, indicam que as analogias entre o perverso dentro e fora dela se devem às mesmas tendências intrínsecas ao humano, como a tendência ao sacrifício e à idolatria, o que faz da propriedade dessas imagens mais do que apenas um acaso.

Quanto a esses conceitos, retomemos e rearticulemos algumas das teorias já trabalhadas nos capítulos precedentes. O sacrifício é, resumidamente, o processo no qual se constitui a unanimidade no seio de uma coletividade humana pela oposição e 
perseguição a um indivíduo ou grupo, assim canalizando mimeticamente a violência que, devido ao mesmo mimetismo, tende a se generalizar em disputas internas entre seus membros. Essa violência coletiva é vista como uma força autônoma superior à comunidade de que se apoderou, e é a ela que corresponde o conceito de sagrado. Os ritos, que reproduzem o sacrifício, tabus e demais instituições sociais são, em grande medida, formas efetivas desenvolvidas pela humanidade para lidar com essa violência real a que se identifica como o sagrado, mas são vistas como emanando dele e nele se fundamentando, o que justifica e apresenta como inquestionáveis as estruturas sociais e formas de violência específicas que engendram em cada cultura.

Entretanto, embora a maioria das culturas possua conceitos que correspondem ao sagrado impessoal, normalmente ele não é visto como atuando diretamente ao estruturar uma sociedade, mas o faz por intermédio de entidades de contornos mais definidos, que se ligam fortemente a ele, sem uma identificação total, e também estariam sujeitas a suas leis intrínsecas.

Essas podem ser espíritos ancestrais, divindades com as mais distintas características e mesmo autoridades sociais, tais como os reis divinos, que podem não se diferenciar de outras divindades em nada além do fato de estarem fisicamente presentes. A violência sagrada substancializada se encarna ou recobre esses sustentáculos das instituições sociais e os qualifica como sagrados, em sentido adjetivo.

Para aqueles que postulam a existência efetiva de uma realidade transcendente, esta gênese imanente do sagrado pode ser vista como a via natural pela qual a humanidade alcançou a intuição do divino. Entretanto, tal fenômeno psicossocial não é prova quer da existência quer da inexistência do transcendente e tampouco diz algo acerca de sua natureza. Isto importa, pois a concepção de idolatria que aqui se emprega foi concebida por pensadores que creem em um absoluto transcendente, o qual está para além da ambivalência do sagrado, de qualquer prescrição ou proibição. Para eles, a idolatria é a absolutização de qualquer coisa que não este absoluto. 
Não importa o que se torne objeto de idolatria, será o valor último no horizonte de um indivíduo ou coletividade e, portanto, seu critério ético, consciente ou não; quase sempre legitimando ou exigindo a perda de vidas humanas ou seu rebaixamento extremo, ao que também podemos chamar sacrifício.

Em sentido oposto, o único que a eleição do absoluto como valor final pode demandar, não como uma exigência partindo dele, mas por ser a única atitude condizente e, acredito (sem maior problematização), o melhor para o ser humano, é a libertação da idolatria e a recusa aos sacrifícios que exige. Entretanto, essa libertação não significa inação, pois sua consequência óbvia é a de que a liberdade não seria verdadeira caso não resistisse ao teste da ação no mundo, e, já que esta não poderia visar, de acordo com o critério do absoluto, se não a auxiliar os demais (a nível individual e coletivo) a alcançar a mesma libertação de forma não impositiva, o único objetivo concreto possível para essa ação no mundo é a luta contra a idolatria e o sacrifício.

Como se vê, o sagrado, no sentido acima definido, é o objeto limite da idolatria, porém, novamente, é abstrato demais para sustentá-la por si mesmo, e quase inevitavelmente serão seus representantes sagrados e as próprias estruturas sociais a assumirem o papel de ídolos. A violência que esse sagrado representa pretende, sempre, ser absoluta, e se volta contra qualquer violência que não se encaixe em seus limites, o que leva, além da repressão de dissidências internas a cada grupo, a, como discute Maurício Righi ${ }^{55}$, uma tentativa de aglutinação dos diversos centros de violência sacrificial, que se refundem em civilizações imperialistas ${ }^{56}$.

Já as culturas tribais apresentam fortes distinções sociais em seu interior, mas as sociedades resultantes de tais processos de aglutinação tendem a ser ainda muito mais complexas deste ponto de vista. A submissão de outros povos, além de muitas e

\footnotetext{
${ }^{55}$ RIGHI, Maurício G. Pré-História \& História: As instituições e as ideias em seus fundamentos religiosos. São Paulo: É Realizações, 2017.

${ }^{56}$ Embora a imposição de uma divindade única ou panteão limitado aos povos conquistados possa ser, na prática, uma violência ainda maior, a incorporação das divindades dos vencidos em um panteão sempre flexível é manifestação deste desejo de aglutinação e monopólio da violência sagrada, e diversas mitologias apresentam sinais destas sobreposições de tradições diversas. Embora esse sistema possa facilitar a incorporação dos vencidos dispostos a aderir ao culto unânime desse sagrado em expansão, ele não é menos violento, e torna os que não estão dispostos a fazê-lo, como, no Império Romano, os judeus, e, antes que se apoderassem de sua estrutura, os cristãos, em bodes expiatórios privilegiados.
} 
variadas contingências nos jogos internos de poder, dão origem a classes sociais mais ou menos bem delimitadas, em especial a distinção entre senhores e escravos, além de facções de interesses distintos e frequentemente conflitantes. Embora os limites entre elas, muitas vezes, não sejam tão claros, podemos considerar que no interior de cada uma, o mimetismo e as tendências sacrificiais continuam a atuar, bem como na dinâmica entre elas, cada grupo social baseando sua coesão na eleição de seus bodes expiatórios internos e externos, individuais e coletivos, tendo irmãos inimigos em seu seio e tomando-se uns aos outros como tal.

Exemplificando com uma distinção simplista entre "opressores" e "oprimidos", é fácil ver como os primeiros se constituem em modelos-obstáculo para os segundos que, quando não se deixam fascinar de modo mais passivo por sua opulência, desejam - mesmo por razões muito práticas - os bens que não apenas gozam, mas ostentam, designando, em um double-bind, como objetos de desejo aos quais barram o acesso ${ }^{57}$. Como se vê, embora seja menos evidente, também os explorados são um modelo mimético para os exploradores e não apenas como espelho narcísico cujo olhar valida sua glória, mas muitas vezes, embora mesclado com desprezo, os poderosos projetam neles uma imagem idealizada de liberdade e despreocupação, a aurea mediucritas, pela qual suspiram (sem estar dispostos à permuta de posições).

Apontar essas relações miméticas não significa, de forma alguma, negar o enorme peso das motivações mais diretamente econômicas, mas apenas ressaltar que também os interesses econômicos não são um campo de desejos espontâneos ou motivados pelo valor intrínseco e evidente de seus objetos. Aliás, na introdução de Sociologia do romance ${ }^{58}$, Goldman apresenta, de modo um tanto equivocado, mas muito fecundo, a teoria mimética de Girard como se seu objeto principal fossem as relações econômicas, o que mereceria ser mais desenvolvido.

Focando, agora, no sacrificial, como mencionado brevemente no primeiro capítulo, a exploração constante dos oprimidos constitui um sacrifício idolátrico. Seu

\footnotetext{
${ }^{57}$ Para uma instigante análise do double-bind nas relações entre classes sociais, bem como entre nações hegemônicas e periféricas, particularmente no campo cultural, ver ROCHA, João Cezar de Castro. Culturas Shakespearianas: teoria mimética e os desafios da mímesis em circunstâncias não hegemônicas. São Paulo: É realizações, 2017.

${ }^{58}$ GOLDMAN, Lucien. Sociologia do romance. São Paulo: Paz e Terra, 1976.
} 
sofrimento, sua constante carência e a violência direta a que são submetidos é vista como necessária para a manutenção da ordem social idolatrada e mesmo, em sociedades nas quais a separação entre o laico e o religioso não se deu, como necessárias para a glória dos deuses e autoridades divinizadas direta ou indiretamente.

Ainda mais, eles são frequentemente responsabilizados pelo mal próprio - o que pode se embasar nas mais diferentes justificativas mitológicas ou na mais simples acusação de incompetência e preguiça -, por instabilidades sociais ou mesmo por uma suposta decadência moral. Isso os torna ainda mais claramente bodes expiatórios em sentido girardiano, nos quais se projeta a culpa pelos conflitos coletivos e a responsabilidade pelo próprio sacrifício. Isso chega ao máximo nos casos em que indivíduos pertencentes às classes exploradas se tornam culpados por crimes, ou deles são acusados, sofrendo uma punição unânime, quer através dos mecanismos jurídicos - originalmente, e em grande medida ainda hoje, ritualizados -, quer pela ação direta de linchadores ou vingadores coletivamente autorizados; ou em escala maior quando se erguem coletivamente em revolta, o que inúmeras vezes provoca seu massacre, visto como um ato de pacificação social e reestabelecimento da ordem.

Os oprimidos, por sua vez (com muito maiores motivos), tendem a responsabilizar os poderosos por seus males. Ao fazê-lo, raramente têm consciência dos mecanismos estruturais pelos quais isso se dá; via de regra os responsabilizam como se sua culpa se tratasse de falhas morais, neles projetando crimes que, se muitas vezes são de fato praticados, não são o cerne do problema. Sua hostilidade se concentra, principalmente, em indivíduos, e particularmente naqueles colocados - ou que ao menos pareçam se colocar - nas posições sociais mais altas, sobretudo governantes. Assim, embora as condições o tornem mais raro, quando as circunstâncias o permitem, indivíduos das classes detentoras do poder podem tornarse vítimas da violência direta dos explorados, para não falar na possibilidade de que estes sejam utilizados como massa de manobra e se deixem direcionar contra bodes expiatórios designados por outros que já participem das classes dominantes.

Claro que, como já dito, esta divisão é extremamente simplista, pois, além da margem de indefinição quanto ao pertencimento a dada classe que pode haver 
mesmo nas sociedades mais rigidamente segmentadas, devemos voltar a atentar para a tendência de unanimidade atuante nos mecanismos sacrificiais. Não apenas os poderosos tomam uns aos outros como bodes expiatórios em suas disputas, podendo direcionar ou ser espontaneamente seguidos pelos oprimidos, como em geral grandes parcelas destes últimos não questionam os ídolos e a ideologia que justificam seu próprio sacrifício. Assim, todo sacrifício tenderá a criar uma unanimidade, ainda que a divergência sempre permaneça fora dela, e a depender do caso essa unanimidade pode se restringir ao interior de um grupo fechado, ou congregar mais de um grupo em sua totalidade, ou se compor por parcelas de grupos, a coesão de uma sociedade complexa se formando, além de outros laços, em grande medida por este intercruzamento de unanimidades sacrificiais, além dos ídolos e ideologias que, do mesmo modo, em parte se identificam com grupos fechados e em parte se entrecruzam.

Qualquer tentativa de transformação dos modos de dirigir uma sociedade, quer parta dos oprimidos ou dos opressores, é orientada pelos ídolos e valores dos que a conduzem.

Pode-se tratar de disputas pelo monopólio do poder dentro do mesmo sistema em que surge a dissidência, portanto se orientando pelos mesmos ídolos sem questionar seus valores; de um questionamento da conformidade do sistema atual, ou ao menos de seus dirigentes, aos valores que este já assume ao menos discursivamente; de uma tentativa de instaurar novos ídolos e supostamente novos valores em lugar dos vigentes; ou, raramente, de uma revolta contra qualquer autoridade, supostamente sem a intenção de instaurar qualquer ídolo em seu lugar, entretanto sendo, talvez, impossível que mesmo as versões nascidas da mais direta impossibilidade de suportar mais tempo a situação vigente deixem de manifestar implicitamente uma estrutura valorativa.

Evidentemente, os que promovem essas tentativas de reforma ou revolução sempre consideram que a transformação pela qual lutam é diferente e superior àquilo que procuram substituir. Não obstante, ao menos ao tomarmos como critério a diminuição na quantidade de violência e sofrimento, muito frequentemente é difícil 
estar seguro de que tais transformações sociais representaram de fato um avanço, tanto em termos da violência que custaram para ser obtidas quanto, e isso é mais consternante, em termos daquela que empregam para se manter.

Historicamente, nem sempre são esses os critérios adotados pelos que promovem tentativas de transformações sociais, mas, mesmo quando em outros contextos culturais estão completamente ausentes, a violência promovida busca se legitimar por servir aos valores que foram assumidos. Assim, se bem que discutir a validade de tais ou tais valores em si seja mais difícil - embora de forma alguma impossível - podemos discutir ao menos em que medida os métodos empregados para sua consecução contribuem de fato para ela, ou mesmo se não os contradizem. Já nas sociedades ocidentais e ocidentalizadas dos últimos séculos a diminuição da violência e opressão tende a mesclar-se com os demais objetivos que qualquer tentativa revolucionária se propõe, e por isso os resultados obtidos nesse sentido serão um dos principais critérios para julgá-las em seus próprios termos.

Uma terminologia interessante para pensar estas contradições entre valores e meios para sua realização é a de Juan Luis Segundo, que chama aos primeiros fé (em sentido antropológico) e aos últimos ideologia. Assim, por exemplo, o ideal revolucionário não pode se tratar de uma fé, pois a transformação de um sistema social não poderia ser um valor por si, mas só se justificaria por visar realizar determinados valores. Entretanto, é muito comum que no curso do empenho para realizar sua fé, o agente passe a identificá-la com sua ideologia, se torne incapaz de diferenciá-las e, mesmo, perca a primeira de vista. Nesses casos, podemos considerar que a ideologia se tornou idolatria - a propósito, sendo interessante notar que ambos os termos têm a mesma etimologia, o grego eidos (imagem) - e esse é frequentemente o caso da defesa da revolução.

A revolução não se sustenta como um valor autorreferente, pois a conquista de bens concretos é parte inerente de sua ideia. Caso tudo que se tenha em vista com a tomada do poder seja a substituição de dado regime por um outro, tratar-se-á bastante precisamente de um caso grave de mediação interna, em que os revolucionários, no papel de discípulo mimético, se guiarão apenas pelo desejo pouco 
claro de se apropriar do ser de seu modelo obstáculo, crendo confusamente que ao obter aquilo que possui (o governo) a sociedade alcançará instantaneamente a plenitude de ser, realizando os ideais, em si abstratos, de justiça, fraternidade -etc.

Para a maioria dos que aderem a um ideal revolucionário é este, provavelmente, o caso. Entretanto, obviamente, há muitos outros que têm objetivos muito mais precisos em vista. Seja qual for o caso, quase sempre, ao menos no plano discursivo, e muitas vezes também na prática, estarão dispostos a perder a própria vida em nome da revolução e pregam aos outros essa atitude como a única moralmente aceitável; o que, aliás, é importante lembrar, muitas vezes é o caso também dos que lutam ao lado das forças repressivas, embora, quem sabe, possamos considerar que entre estes é mais fácil uma maior tendência à autoconservação, já que lutar ao lado do poder estabelecido é sempre mais cômodo, a menos quando sua ruína se faz iminente.

Isso seria, em princípio, um autossacrifício negativo: "O ídolo é maior do que nós, e exige nossa morte". Não obstante, é difícil julgar tão simplesmente aqueles que estão dispostos a abrir mão de tudo por aquilo que julgam ser o melhor para os demais. Em sua obra já mencionada, Juan Luis Segundo diferencia as atitudes simplesmente autodestrutivas do martírio, entendido como a disposição de seguir as consequências de sua fé, os valores últimos em seu horizonte, até a morte, quando não fazê-lo significaria abrir mão da essência desses valores. Ao discutir o problema, ele parece dar uma conotação puramente positiva ao termo, sendo que, de um ponto de vista axiologicamente neutro, não haveria obstáculos em se aplica "fés" - ou pelo menos ideologias, caso pressuponhamos, como uma antiga tradição que parece influenciá-lo, que ao fim o ser humano sempre procura, mesmo que em caminhos inteiramente equivocados, o verdadeiro bem - bastante questionáveis, e poderíamos falar, por exemplo, em mártires do imperialismo e do nazismo bem como de mártires da revolução burguesa, do marxismo ou do cristianismo.

Certos autores da teologia da libertação preferem diferenciar o autossacrifício, no sentido da entrega idolátrica da própria vida, da autodoação amorosa pelo outro. 
Para fazermos essa distinção, porém, já será preciso entrar na discussão ética dos valores que motivam a disposição de perder a vida em cada caso.

Para Girard, como já ficou claro, o critério para essa diferenciação é a aceitação ou denúncia da lógica persecutória, que apresenta a violência do sacrifício como necessária. Por muito tempo ele rejeita a utilização da palavra "sacrifício" em sentido positivo, criticando particularmente sua aplicação à morte de Cristo. Posteriormente ele revê essa posição, considerando que o emprego da palavra não é em si um problema, desde que a sua interpretação siga apresentando este sacrifício como uma violência humana e sua aceitação por Jesus como uma denúncia de sua lógica e do sacrifício de todas as vítimas.

Para ele, a crucifixão é o exemplo máximo dessa morte antissacrificial, pois não é apresentada, como muitos o interpretam, como exigida por Deus, mas como sendo a consequência inevitável mas contingente do enfrentamento às tendências sacrificiais de sua sociedade, revelando-as e questionando-as ao se consumar.

Estes mesmos critérios podem ser empregados na avaliação da disposição a se perder a vida em qualquer contexto. Uma coisa é estar disposto a aceitar a morte na luta por uma causa, seja ela qual for, outra é tomar essa morte como um objetivo em si, como muitas vezes é o caso no discurso revolucionário e pode ser observado na literatura que o incorpora ou retrata. Além disso, quer chamemos essa disposição de martírio, doação ou mesmo sacrifício, há grande diferença no caso em que ao menos seus objetivos explícitos visem o combate às estruturas e tendências sacrificiais ou as defendam, como seria o caso do nazismo ou do imperialismo, para retomar os exemplos acima. Claro que mesmo o discurso destes movimentos se propõe objetivos abstratamente louváveis, mas mesmo a sociedade utópica que pretendem criar mantém a legitimação de estruturas de violência e exclusão sacrificiais, o que é diferente daquilo que almejam, por outro lado, os melhores exemplos do discurso cristão ou marxista, independentemente da realidade que os esforços por realizá-los possam produzir.

Em suma, apenas quando a aceitação da própria morte se dá de modo que não legitime quer o autossacrifício quer a manutenção do sacrificialismo social é que 
poderíamos não considerá-la sacrificial, no sentido negativo que vem sendo empregado nesta pesquisa.

Já mais problemático, no que diz respeito à revolução armada, é a questão da morte do outro, da qual por definição não poderia desvencilhar-se. Isso torna impossível que sua ideia escape ao sacrificialismo.

Em geral (mesmo que em outros termos) seu sacrificialismo se justifica pela ideia de criar uma sociedade livre de sacrifícios, o que, entretanto, mesmo desconsiderando o fato de que esse ideal não parece alcançável por tais meios - e provavelmente jamais seja plenamente realizável -, não elimina seu sacrificialismo. Isso o caracteriza como o "sacrifício dos sacrificadores", que discutimos sobretudo no primeiro capítulo: aquela versão do sacrificialismo em que as vítimas são apresentadas como monstros violentos que perseguem e matam os inocentes, tornando justa sua perseguição e morte, e pode conduzir a algumas das mais extremadas manifestações de sacrifício massivo.

No socialismo burocrático historicamente concretizado há muitos lamentáveis exemplos dessa lógica, muito em particular no stalinismo. Nesse regime, a revolução supostamente realizada, mas não consolidada, segue perseguindo seus inimigos internos monstruosos; a política do partido incentiva a indiferenciação violenta, em que cada indivíduo é suspeito de ser uma partícula invasora abalando a ordem e caso não possa fazer com que essa suspeita recaia sobre o outro tornar-se-á ele mesmo o bode expiatório; espera-se que as vítimas confessem seus crimes e concordem com a justiça de sua punição, garantindo, assim, a unanimidade total em torno de seu sacrifício; e a ideia de autossacrifício pela revolução permanece extremamente intensa, tudo isso mantendo flagrante atmosfera de fanatismo religioso, que os inimigos do socialismo não se cansam de assinalar ${ }^{59}$.

\footnotetext{
${ }^{59}$ Um exemplo curioso destas similaridades com práticas religiosas, mesmo fora do bloco soviético, era a prática da autocrítica dos membros de partidos socialistas. Nela esperava-se que cada um reconhecesse em si falhas e o egoísmo pequeno-burguês, confessando-o aos correligionários, ao que muitos aproximavam a confissão coletiva típica do cristianismo russo. Novamente, cada indivíduo deve oferecer-se como bode expiatório para os demais, garantindo assim uma total unanimidade no grupo que se mantém coeso, mas, no caso, alcança por esse meio a benevolência comunitária, diferente do que acontecia nos julgamentos soviéticos. Na literatura brasileira, essa instituição foi negativamente
} 
Mas reconhecer estes lamentáveis fatos não poderia jamais servir de pretexto a uma condenação de todos aqueles que buscam uma transformação da sociedade, como muitas vezes se fez com grande violência, por exemplo nos regimes autoritários da América Latina e da Península Ibérica ou mesmo nos EUA "democráticos" do período de caça aos comunistas ${ }^{60}$. Isso seria novamente cair na inversão antissacrificial e no sacrifício dos sacrificadores.

Para começar, não se deve esquecer que existem formas não violentas de luta contra aquilo que aqui chamamos de idolatria e sacrifício, embora, nos contextos em que se fazem mais necessárias, adotá-las exija de fato a coragem de atrair contra si a violência a que se opõem e abraçar a disposição da autodoação. Entretanto, por mais que muitos dos que adotam posições próximas às que orientam este trabalho simplesmente condenem, com bons motivos, formas violentas de luta, em geral a revolução armada se ergue contra estruturas de violência tão atuais e aparentemente inabaláveis que não é possível simplesmente condená-las a priori. Felizmente não compete a este trabalho decidir quanto à existência ou não da violência revolucionária na história, mas simplesmente analisar os elementos sacrificiais presentes tanto nela quanto nas sociedades a que se opõe e mesmo nas novas estruturas que vem a produzir, o que cada um deveria levar em conta ao fazer suas opções práticas.

Ainda assim, antes de passar à análise dessa problemática em obras literárias, gostaria de deixar claro minha crença na superioridade das tentativas não violentas de transformação da sociedade. Mesmo à parte a dificuldade de se legitimar a violência em si, seja quais forem seus objetivos e mesmo resultados práticos, parece claro que ao ser arrebatado violentamente o poder se concentrará de modo excessivo nas mãos dos que o tomaram, os quais, ainda quando não se deixassem corromper por ele, seriam obrigados a empregá-lo também de modo excessivo para consolidá-lo e conter as reações violentas à violência própria. Assim, apenas as práticas não violentas podem esperar contribuir para uma distribuição mais equilibrada de poder, uma diminuição da violência em dada sociedade e, em certo sentido, mesmo a um aumento da justiça em seu interior, ainda que seus resultados pontuais sejam limitados e em muitos casos 
o cômputo geral se mostre negativo. Assim, quer em um regime consolidado há tempo o bastante para que suas origens violentas tendam a se perder de vista, quer naqueles que se estabeleceram há suficientemente pouco tempo para que ainda seja preciso que busquem justificá-la, a oposição não violenta e que busque, tão concretamente quanto lhe for possível, tomar a defesa das vítimas de sua sociedade é um contrapeso necessário, e qualquer forma de poder que a persiga violentamente terá grande dificuldade de se legitimar do ponto de vista ético.

\section{Conflitos sociais e os ciclos sacrificiais em Germinal}

Em Germinal ${ }^{61}$, Zola, o criador do naturalismo, pretende representar com precisão científica condições bastante extremadas de exploração capitalista nas minas de carvão francesas, a degradação das massas operárias e sua reação ao aderir de modo pouco consistente às tendências revolucionárias que ganhavam força à época em toda a Europa. Sem ser socialista, as posições do autor incomodavam tanto a direita da época - particularmente ao sustentar a inocência do oficial Dreyfus durante o famoso escândalo que ficou conhecido como "Caso Dreyfus" - que, ao que parece, levaram a seu assassinato. Por outro lado, entre marxistas e defensores da revolução, muitas vezes o criticam duramente por dar uma representação pouco favorável das classes exploradas e dos movimentos de massa, o que contraria seus objetivos práticos de influenciar as forças sociais em favor da revolução e contraria seus ideais.

De fato, as teorias científicas da época contêm grande dose de violência contra os mais pobres, apresentando sua miséria como resultado de uma degradação biológica de base hereditária, enfatizando inclusive a suposta transmissão de vícios adquiridos, como o do alcoolismo, para que não faltasse a devida dose de culpabilização moral dos miseráveis até mesmo por sua condição supostamente natural. Zola aceitava inteiramente essas teorias, e suas obras, entre elas Germinal, refletem inúmeras vezes esta extrema inferiorização do outro em sua linguagem, na animalização de seus personagens e por meio da utilização direta dessas teorias por

\footnotetext{
${ }^{61}$ ZOLA, Émile. Germinal. Disponível em áudio em http://www.litteratureaudio.com/livre-audio-gratuitmp3/zola-emile-germinal.html
} 
parte do narrador. Entretanto, sua força literária transcende em muito esses limites, e seu trabalho ficcional sobre a realidade que observa nos oferece intuições muito mais profundas do que seu cientificismo ultrapassado.

Para começar, as atitudes e ações de seus personagens se sustentam por si mesmas, e podem ser analisadas proveitosamente em chaves distintas do determinismo naturalista que, digamos, o autor aplica externamente a elas, inclusive em termos miméticos. Além disso, aquilo que aparece como uma degradação da classe operária explorada ao limite, embora não possa jamais ser atribuído a fatores biológicos, é em grande medida uma realidade, sendo fruto e uma das mais terríveis consequências da violência social que sofre. Ela não é, de modo algum, absoluta, mas negá-la e construir uma visão idealizada das classes exploradas é negar sua alteridade e se recusar a ver a dignidade máxima que têm mesmo que sua forma de ser pareça incômoda aos que provêm de outros meios sociais e gostariam de projetar nelas suas esperanças e ideais. O próprio Zola, aliás, em meio a todo o preconceito que possa assumir com relação a essas classes, certamente demonstra grande simpatia por elas, e com grande frequência representa literariamente sua dignidade e valor, parecendo, mesmo, crer na inevitabilidade de seu triunfo final, mesmo sem apresentá-lo como o mais alto bem desejável, como era comum em fins do século XIX e princípios do XX.

Quanto a seu tratamento dos movimentos de massa, pareceria pueril negar o fato de que esses são, muitas vezes, explosões de violência cujos resultados não servem a qualquer propósito, mesmo que se reconheça que poderiam ser direcionados a fins mais precisos. Em Germinal há muitos exemplos desses movimentos, e, é fácil prever, os analisaremos em termos sacrificiais. Zola os compõe de modo a destacar, talvez com um toque de sensacionalismo, a inocência relativa de suas vítimas concretas ou, poderíamos dizer, o caráter substitutivo de suas mortes, já que seu sacrifício se dá em lugar de um ataque real ao sistema opressor que desperta a revolta justificada dos operários, o qual termina, até mesmo, reforçado com parte deles.

Como veremos mais à frente, por vezes o autor chega a comparar diretamente esses movimentos de massa a manifestações propriamente sacrificiais, mas não é 
apenas com relação a estes fenômenos que ele o faz. Em sua obra é muito frequente aquilo que indicamos na introdução deste capítulo: a aproximação explícita entre fenômenos e estruturas sociais profanos e elementos religiosos ou míticos sacrificiais como uma forma de crítica. Em seu estilo muito menos austero e frio do que imaginariam aqueles que conhecessem apenas descrições didáticas ou as teorias programáticas da escola naturalista, Zola une suas minuciosas descrições "científicas" a símiles de caráter mítico, um de seus recursos recorrentes sendo comparar tudo aquilo a que atribui o poder de atrair e exaurir seres humanos a monstros devoradores, quer se trate das grandes lojas representadas pela sua Au Bonheur des Dames, que devora tanto a seus funcionários quanto aos pequenos concorrentes, quer da atriz Nana, que atrairia e devoraria aos amantes que a sustentam.

Assim, também, a mina de carvão de Germinal é comparada a um monstro, cuja boca devora constantemente os carvoeiros que padecem horas a fio um trabalho extremamente insalubre em seu ventre, morrem em seus frequentes acidentes ou adoecem em decorrência das péssimas condições e da exaustão. Logo nos primeiros parágrafos do romance, não apenas a mina física, mas a estrutura econômica que mantém sua exploração, recebem um tratamento mítico. Em meio à madrugada ainda inteiramente escura, em que sopram fortes rajadas de vento, o protagonista Étienne avista sem compreender, o clarão das chamas da fábrica em funcionamento, conferindo uma atmosfera fantástica a este cru ambiente industrial. Então, durante a conversa que tem o jovem operário com o velho père Bonnemort, o narrador compara pela primeira vez a diretoria da companhia carvoeira e seu capital com uma divindade inalcançável e malfazeja, que se nutre constantemente do sangue de seus operários, mas pela qual estes têm um misto de respeito e temor. Não apenas os operários mantêm tal relação com as forças distantes e incompreensíveis que sustentam o modo de vida de que mal concebem escapar, mas, bastante mais à frente, o mesmo respeito crédulo e religioso é atribuído à família Grégoire, cujo conforto ocioso é garantido pela renda proveniente do investimento que um antepassado fez na companhia em seus primórdios.

O caráter idolátrico que essa comparação procura ressaltar não poderia ser mais claro. As estruturas abstratas, nascidas da ação humana, mas que de fato 
escapam de seu controle e se comportam segundo uma lógica interna - no caso os interesses econômicos no mundo capitalista, representados pela companhia carvoeira em particular - são apresentadas como uma entidade autônoma e superior ao ser humano, que determina suas vidas e exige o sacrifício constante de uma parcela significativa da comunidade para manter a ordem que nela reina. Segundo Franz Hinklammert em seu As armas ideológicas da morte ${ }^{62}$, é exatamente a essa atribuição inconsciente (mas que se reflete na linguagem) de vida e autonomia de ação a entidades abstratas - tais como empresas e outras instituições - que Marx chama fetichismo, em nível mais amplo ele falando, como mencionado, em "idolatria de mercado". É exatamente a mesma ideia que Zola reflete ao apresentar seus personagens, quer se favoreçam, quer se prejudiquem ao máximo, mantendo um respeito comum pela entidade abstrata que rege seu modo de vida, tal como se cultuassem a um deus.

Para Zola, certamente, de acordo com sua posição positivista, essa aproximação tem o fim de desvalorizar a mentalidade dos operários e dos burgueses mais ingênuos ao compará-la com o religioso, que via como paradigma de irracionalidade e superstição. Para Marx, com alguma sofisticação mais, a religião é o modelo original da ideologia, significando exatamente a submissão voluntária do ser humano a entidades criadas por ele, mas das quais ele se acredita dependente, de modo a justificar as estruturas sociais existentes e dissuadir tentativas de transformação. De qualquer forma, o que aqui interessa é que a utilização desta ordem de imagens na obra de Zola indica uma continuidade de dinâmicas e tendências comuns às mais antigas formas de religião e às estruturas sociais do industrialismo laicizado que Ihe era contemporâneo, ainda que o autor não possuísse plena consciência de até que ponto isso era verdadeiro.

Tais aproximações com o religioso pontuam o romance durante toda sua extensão, e não apenas se referindo às atitudes conformistas ou conservadoras, mas voltaremos a isso mais à frente. Antes será interessante examinar a já mencionada presença, não inteiramente explorada, de elementos miméticos na descrição dos

\footnotetext{
${ }^{62}$ HINKELAMMERT, Franz. As armas ideológicas da morte. São Paulo: Editora Paulinas, 1983.
} 
relacionamentos e da interação entre os personagens de Zola, tanto no nível individual quanto no da coletividade. E para isso seguiremos a trajetória do protagonista Étienne.

Tendo perdido seu emprego, que Ihe garantia uma situação algo menos má que a dos mineiros, o jovem é forçado a adotar sua profissão e se incorporar a seu meio. Logo em seu primeiro dia se estabelece uma rivalidade entre ele e o veterano Chaval, na qual, como, talvez, na maioria das rivalidades ficcionais, o mimetismo é perceptível, mas sem que a intuição do autor chegue longe o bastante para revelar toda sua profundidade.

No caso, além da má vontade imediata do antagonista pelo recém-chegado, o primeiro objeto em torno do qual se estabelece a rivalidade é a jovem operária Catherine. No livro, o desejo de nenhum dos homens é apresentado como provocado pelo modelo do outro. Chaval já tinha interesse pela garota havia algum tempo, mas negligenciara a iniciativa de começar uma relação com ela. Étienne, de seu lado, sente que não seria difícil ficar com a garota devido ao clima de camaradagem que logo se estabelece entre ambos, mas, enquanto hesita em dar o primeiro passo permite que 0 outro tome a frente, beijando brutalmente a Catherine, o que força o orgulho do primeiro a abrir mão de seu desejo, até então superficial e fraco, mas que o malogro fortalece e exaspera. Assim, o desejo prévio de Chaval é reforçado pelo modelo de Étienne, e o leva a agir como forma de se afirmar contra o rival, enquanto o modelo obstáculo que ele próprio passa a constituir para o outro aumenta o desejo deste último.

Apesar deste laço de má reciprocidade que une os dois personagens, o autor não descreve sua relação de modo a destacar a simetria entre os duplos miméticos. Embora Étienne esteja longe de ser um herói sem falhas, a simpatia do narrador está muito mais de seu lado, enquanto Chaval é que concentra as características de inveja, egoísmo e ressentimento em princípio desmotivados ${ }^{63}$. Além disso, a própria Catherine prefere desde o início Étienne, mas é passiva demais para desfazer a situação provocada pela imposição de um e o afastamento do outro, o que prolonga este

\footnotetext{
${ }^{63}$ Aliás, não há nada de implausível que entre um par de indivíduos presos em uma relação de rivalidade mimética um a viva de modo mais intenso e negativo que o outro. Trata-se apenas de destacar a opção literária de Zola, que não Ihe permite tirar o máximo da relação mimética que criou.
} 
estado de coisas durante quase todo o romance, ao mesmo tempo levando adiante a assimetria entre os rivais, já que Chaval aparece desta maneira como um tirano que se impõe à moça.

Outro terreno em que, mais tarde, se manifestará a rivalidade entre Étienne e Chaval, sobretudo sob forma de inveja deste último, é o da disputa pelo prestígio e a liderança entre os companheiros de trabalho. Esta é uma área, aliás, em que o mimetismo e a rivalidade atuam de modo muito particular, o próprio protagonista dando seus primeiros passos nesse caminho guiado pelo que poderíamos considerar como uma mediação externa não conflitiva, para pouco depois entrar em conflito com seus modelos, passando à mediação interna.

Apesar das duras condições de trabalho, Étienne logo se adapta à sua nova condição e meio. Seu gênio combativo, porém, faz com que ele se torne solo fértil para a influência de Rasseneur e Souvarine. O primeiro, antigo mineiro demitido por sua atuação à frente de seus companheiros, o qual conseguiu abrir um bar e continua tendo grande influência sobre os trabalhadores, não segue qualquer vertente ideológica definida, e apenas representa uma espécie de catalisador da indignação de seus ex-companheiros, sendo bastante moderado, ao passo que sua esposa é bastante mais extremista e prega sempre a luta. Ainda assim, é o discurso indignado do taverneiro e de seus clientes que leva Étienne a se interessar pela ideia da luta operária. Além disso, inicialmente Étienne se aloja em um quarto alugado por Rasseneur em sua taverna, onde também ele mora, o que dá um toque de rebeldia filial ao futuro rompimento do jovem com o homem mais velho que o acolheu e influenciou.

Mas para que Étienne fosse além dessa primeira posição de revolta abstrata e assumisse a posição proeminente que teria entre os companheiros, o anarquista russo de tendências terroristas Souvarine seria essencial. Este solitário e altivo personagem, cujo passado se nos revela pouco a pouco, com vislumbres de sua participação em uma tentativa malograda de assassinar o Czar e da execução de sua amada, desdenha os ideais comparativamente moderados de republicanos ou socialistas, mas se deixa seduzir pelo interesse que desperta em Étienne, e as leituras que indica a este último - 
às quais ele compreende mal e com pouca capacidade de diferenciar entre as correntes diversas que representam - é que se constituirão no grande modelo que conduzirá o idealismo do jovem e o levará a propor a criação de um caixa de previdência para garantir fundos em caso de greve e a associação dos mineiros de Montsou à Internacional.

À medida que a popularidade de Étienne cresce, a conjuntura leva a um aumento das tensões entre a empresa e os trabalhadores, culminando com a longa greve que constitui o centro da obra. As decisões acerca do movimento se dão através de assembleias, espaço particularmente propício para a atuação do mimetismo, e é nelas que a oposição entre Étienne e Rasseneur atinge o ápice. Neste sistema de escolha coletiva em que as decisões devem ser tomadas de imediato, o principal fator para o sucesso ou fracasso de uma proposta é a capacidade dos que a defendem de despertar um impulso grupal entre os indivíduos que a compõem, o que, por sua vez, depende em grande medida do prestígio prévio dos discursantes e de sua adequação às tendências já presentes na coletividade. Desse modo, as assembleias são o local ideal para verificar e consolidar a ascensão e o declínio das lideranças de um grupo, em um processo bastante similar àquilo que atuava na democracia ateniense, que tão brevemente analisamos no primeiro capítulo. É assim que em Germinal vemos o discurso moderado de Rasseneur, que se opõe à greve, ser rejeitado pelos companheiros entre os quais outrora era a maior influência, e que agora se mostram agressivos, lançando contra ele acusações que vão de covardia até a traição. Neste ambiente mimeticamente carregado e tendente à produção da unanimidade, as vozes que se levantam contra esta convertem-se em bodes expiatórios que a fortalecem, e os candidatos ideais para essa posição são os que outrora se mostraram hábeis em conduzir as forças deste processo, mas que por algum motivo perderam essa capacidade. É o que acontece com Rasseneur, cuja queda confirma a ascensão de Étienne à posição de liderança que ocupava, para que, no entanto, o jovem discípulo percorra a mesma rota que seu modelo e tantos antes deles em muito menor tempo e de modo muito mais espetacular devido às dimensões crescentes da crise.

Mas voltaremos a isso em breve. Antes, examinaremos como também a essas tendências de revolta coletiva Zola_ trata de modo a destacar seu sacrificialismo, já 
esboçado nas assembleias, e traçar uma aproximação com o religioso, ou seja, reconhecendo elementos comuns às manifestações aparentemente opostas de conformismo e de rebelião.

Com relação à religião propriamente dita, os trabalhadores se mostravam em geral descrentes, mas ainda antes da greve, quando Étienne falava de seus ideais utópicos de uma sociedade mais justa, o narrador comparava a esperança dos mineiros à fé nas promessas tradicionais do cristianismo, destacando, em particular no caso da mãe de Catherine, a Maheude, o conflito entre o desejo de crer e a desilusão provocada por sua dura realidade, que desaconselhava nutrir essas esperanças para depois perdê-las. Mas Zola não apenas mostra o que haveria de ilusão religiosa nas esperanças utópicas de transformação social. Sua aproximação torna-se de mão dupla pela inserção, não particularmente relevante no desenrolar da história, de um padre excêntrico que representa, por sua vez, tendências exaltadas da religião, o qual vive a condenar moralmente os burgueses e responsabilizá-los pela miséria dos trabalhadores, aos quais garante que serão vingados por Deus por meio da igreja, que recobrando o poder temporal que teria perdido para a burguesia, graças ao retorno dos miseráveis a seu seio, repararia todas as injustiças. Este personagem secundário representa uma linha do discurso religioso preocupada com as injustiças terrenas, mas que, diferente de outras que buscam associar a luta concreta à fé religiosa, apenas esperava uma intervenção mais ou menos messiânica e direta de alguma instância sobrenatural caso os fieis adotassem a atitude correta.

Talvez um dos objetivos de Zola com sua presença na obra, fosse representar os conflitos entre o poder político laicizado e a influência da Igreja Católica, tão forte na França durante todo o século XIX, bem como a ideia muito comum à época de que a religião cumpriria a função social de capitalizar a revolta dos oprimidos, nela projetada de modo ilusório, assim os afastando da revolta real e garantindo a estabilidade social. Entretanto, o modo como isso aparece no romance ressalta que esse não é necessariamente um caso de manipulação ideológica programada por parte dos poderosos, pois a posição desse representante do baixo clero não está, de modo algum, em acordo com os interesses dos representantes oficiais do poder eclesiástico, que chegaram a afastá-lo devido ao desconforto provocado por sua pregação após 
graves incidentes ligados à greve com a qual, aliás, ele jamais se envolve. Isso indicaria, independentemente das intenções do autor, que a ligação entre a revolta popular e certas formas de religiosidade têm raízes mais profundas, ainda que, no contexto particular representado na obra, aquela tenha se dissociado quase inteiramente da religiosidade propriamente dita. E Zola segue ressaltando o que haveria de religioso nessa revolta popular em suas eclosões mais intensas e altamente sacrificiais.

Penso, em particular, em uma sequência de eventos que reúne mais de um dentre os pontos que viemos observando. Em um dado momento, quando a greve dura já algum tempo, a despeito das grandes dificuldades a que devem se submeter os mineiros, mas não há sinal de vitória à vista, dá-se uma nova assembleia na floresta, durante a qual, novamente, o autor emprega comparações religiosas, aproximando Étienne a um apóstolo e os mineiros a uma comunidade religiosa disposta a tornar realidade por si própria as promessas que se cansou de esperar. Nela, Chaval - que devido às circunstâncias a essa altura abandonara a companhia e se empregara com Catherine na mina de Jean Bart, um pequeno concorrente - observa com despeito o prestígio do rival e, mimeticamente, deseja alcançar uma posição de liderança semelhante à dele. Com alguma habilidade, consegue dar um passo nessa direção convertendo o início de um impulso de torná-lo bode expiatório devido ao fato de que os trabalhadores de sua mina não aderiram à greve e, portanto, estariam prejudicando o movimento, em louros para si, inventando que fora à reunião para anunciar que os colegas adeririam finalmente à luta, o que lhe rende os aplausos de todos.

Chaval satisfaz, assim, seu desejo mimético de equiparar-se ao rival e o de ser reconhecido pela massa a um só tempo. Ele poderia, inclusive, consolidar em alguma medida sua verdadeira liderança entre os colegas, pois não tem dificuldade para convencê-los efetivamente a não descerem à mina, porém, coerentemente com a falta de caráter com que o autor vinha construindo sua personagem, ele prefere as promessas de promoção feitas pelo patrão e novamente convence os demais a voltarem ao serviço. 
Quando os grevistas se dão conta da traição, que agora o é de fato, sua fúria contra os companheiros renitentes é grande, e em particular contra Chaval, que neste ponto passa muito perto de se tornar por completo um bode expiatório e ser linchado.

$\mathrm{Na}$ verdade, antes mesmo que o antagonista de Étienne fosse identificado entre os que haviam descido para o trabalho, a excitação coletiva da multidão se mostra como uma violência mal contida que diversas vezes se inclina a concentrar-se em um bode expiatório particular durante o dia, cuja narração ocupa toda a quinta parte da obra. O primeiro candidato a vítima dessa violência coletiva é Deneulin, o dono de Jean Bart, cuja personalidade forte o leva a afrontar os grevistas imprudentemente, até que seus contramestres o afastam à força, o que leva os trabalhadores a se voltarem contra os equipamentos da mina, a destruição dos quais, devido à já mencionada maneira de Zola de descrever construções como seres vivos, se assemelha muito a um assassinato coletivo, o qual se repetirá diversas vezes ao longo do dia, já que os grevistas peregrinam de uma a outra das várias minas da região, sempre desejosos de vingança contra os patrões e os trabalhadores que não aderiram ao movimento, e sempre repetindo os danos aos equipamentos. Chaval é forçado a acompanhá-los, e diversas vezes se torna o centro da agressividade coletiva, até que Catherine convence Étienne a deixá-lo partir.

Rumo ao final do dia, as ameaças de sacrifício que seguem ocorrendo se tornam cada vez mais perigosas, uma das últimas a quase sucumbir ao furor dos grevistas sendo Cécile Grégoire - a ingênua filha da família burguesa que partilhava, de seu ponto de vista tão diferente, o antigo respeito religioso dos trabalhadores pela companhia -, que, caindo por acaso nas mãos dos operários, atrai, em particular, o ressentimento das mulheres, que durante esta longa sequência são sempre descritas com toques particularmente grotescos._Também o père Bonnemort, normalmente quase apático, por alguma razão desconhecida se volta contra ela e quase a estrangula, mas essa conclusão drástica é evitada por sua nora, que reconhece a jovem, que ainda assim segue como objeto da agressividade das mulheres.

É interessante notar aqui o modo como Étienne, durante toda a longa jornada, mantém um controle precário e parcial sobre a massa, sempre buscando redirecionar 
sua agressividade de um alvo espontâneo para outro de consequências menos graves, como fizera, por exemplo, ao impedir que seguissem a proposta de um operário de outra mina, que desejava destruir as bombas de água para que esta fosse inundada, propondo que fossem, ao invés disso, a uma em que quase a totalidade dos trabalhadores furava a greve. Também aqui ele tenta o mesmo recurso para salvar Cécile, sugerindo que saqueiem o armazém de Maigrat, o que teria a vantagem prática de obter alimentos para os grevistas famintos de uma longa privação, mas nesse momento a nova vítima substitutiva que propõe não basta, e ele é seguido apenas pelos homens, a garota sendo salva das mulheres - sem um arranhão, aliás - apenas pela chegada de Deneulin, que consegue pô-la a salvo.

Mas embora não tenha obtido o resultado esperado por Étienne, é o ataque ao armazém que conduzirá, acidentalmente, à conclusão sacrificial do dia, pois seu dono, um mesquinho e perverso comerciante que se aproveitava da miséria das famílias para oferecer crédito em troca de favores sexuais de suas mulheres, é levado pela avareza extrema a tentar penetrar na loja para proteger sua mercadoria, e acaba tombando do telhado e morrendo ao bater a cabeça. Embora acidental, essa morte se aproxima muito de um assassinato coletivo, pois decorre, de fato, do ódio da coletividade contra o comerciante, cuja queda se deveu ao tremor provocado pelo medo de receber pedradas, sendo que de fato os grevistas haviam apedrejado outros alvos sem consequências demasiado graves.

Mas, sobretudo, são os efeitos dessa morte que nos permitem considerá-la o sacrifício que encerra esta crise dentro da outra mais ampla que é a greve. Por parte das mulheres, a vingança contra o homem que tanto as atormentara com a fome e o abuso absorve toda sua agressividade, elas se dedicando a violar o cadáver, chegando ao ponto de arrancarem com as mãos os genitais de Maigrat, colocá-los na ponta de um bastão e se rejubilarem ao exibi-los como um troféu; enquanto a agressividade dos homens também se dispersa, embora isso se deva ao choque com o acidente e a cena de selvageria que presenciaram. Essa divisão entre as atitudes dos homens e das mulheres, apresentando os primeiros de modo mais racional e sensato, apesar de tudo, e as outras como tomadas por uma selvageria e barbárie irracionais pode ser questionável, mas contribui para apresentar o episódio como uma espécie de rito pré- 
civilizado, no qual elas atuariam como sacerdotisas, aproximando-as das figuras de bruxas ou mesmo bacantes, tão fortes no imaginário ocidental, e o narrador chega a compará-las, em seu triunfo ao exibir a parte mutilada do cadáver, com as Fúrias, grupo de divindades coletivas particularmente sacrificiais, responsáveis pela vingança de crimes contra os laços de parentesco. Além disso, a cena ainda apresenta semelhanças com os efeitos que Girard atribui ao sacrifício, pois não apenas o mal estar que a morte produz entre os homens desfaz, afinal, a excitação coletiva que tomava a multidão durante todo o longo dia, mas o próprio cadáver atua como uma proteção para a porta que até então tentavam arrombar, ou seja, como no sacrifício (aqui em pequena escala), a vítima assassinada se torna uma presença que atua sobre a comunidade que a matou, instaurando proibições e tabus.

Podemos considerar os grandes acontecimentos do romance a partir deste ponto como uma sucessão de crises sacrificiais cujas resoluções, não sendo fortes o bastante para reconciliar as partes em conflito e reestabelecer uma relativa unanimidade, apenas reforçam as tensões e conduzem a crises de maior violência. Nesse sentido, seu próximo elo é provavelmente o mais impressionante.

Com a continuação da greve, a companhia decide importar mão de obra belga para substituir seus obstinados trabalhadores, o que desperta mais uma vez sua indignação. Entretanto, como em decorrência da desordem precedente, Montsou fora ocupada por tropas militares que deveriam garantir a estabilidade social, a situação se torna extremamente conflitiva, com o destacamento de sessenta soldados que devia proteger a mina se vendo circundado e provocado por centenas de trabalhadores que pretendiam impedir a descida dos estrangeiros.

O foco narrativo se alterna constantemente entre a multidão e os soldados, destacando assim elementos de má reciprocidade no desenvolvimento do episódio, em que as reações cada vez mais exaltadas dos grevistas face às tentativas de intimidação cada vez mais ameaçadoras dos militares, em crescente tensão, leva ao pior. Frente ao assédio ameaçador da multidão, o capitão da tropa ordena que seus homens os ameacem com as pontas das baionetas, o que intensifica a indignação dos civis, que avançam sobre as armas e procuram tomá-las à medida que aumentam os 
insultos que já dirigiam contra os outros; isso leva o comandante a ordenar a prisão de alguns dos opositores, que reagem atirando tijolos partidos. Finalmente, quando o capitão estava prestes a ordenar fogo, seus homens disparam antes que o fizesse, destacando, assim, como a esta altura também estes se viam movidos pela dinâmica mimética de massa mais do que pela simples disciplina militar.

Desde o início da ocupação militar, Zola reforça diversas vezes que as tropas se comportavam como em país inimigo, assim como os próprios mineiros desdenhavam as tentativas de intimidação dos soldados, considerando inconcebível que o exército abrisse fogo contra seus compatriotas. Desse modo, essa catástrofe tem características que reforçam seu caráter de crise de violência intestina entre membros de uma mesma comunidade, aproximando-a, em particular, de uma das formas mais intensas de crises como essas, as guerras civis, que na antiguidade provocavam um horror de natureza religiosa entre os autores que delas tratavam. Além disso, as vítimas individualizadas do conflito são de jaez a aumentar a atrocidade da cena: as duas crianças Lydie e Bébert - que, aliás acabavam de passar sua primeira noite de amor -; a velha Brûlé, que, apesar de ser uma figura grotesca, reforça, por sua idade e gênero, a ideia de inocência, ou, quando menos, inofensividade; a jovem Mouquette, cuja morte tem traços de um puro autossacrifício, já que ela se joga diante de Catherine, que era sua rival pelo amor de Étienne, para salvá-la, e ainda expira aparentemente dando sua bênção ao casal; e, entre outros, o simpático Maheu, o que singulariza e concretiza o desastre no seio da família que recebe maior atenção no romance. Tudo isso contribui para fazer deste evento uma espécie de sacrifício nefasto, cuja consumação foi devida a forças muito além da intenção ou do controle dos envolvidos.

Mais uma vez, este sacrifício coletivo não tem a virtude de refundir a unidade no seio da comunidade como um todo, mas possui efeitos pacificadores, sendo percebido de modo muito distinto entre os operários e a burguesia.

Entre os primeiros, o acontecimento leva ao desânimo e ao abatimento. Ele é, sobretudo, uma catástrofe, e, como tal, exige um bode expiatório, o qual será encontrado em um indivíduo típico, o líder caído em desgraça: Étienne. 
O protagonista, que também se via abatido e desmoralizado após as mortes de seus companheiros, alguns dias após ela acaba atraindo a hostilidade de seus colegas. Estes, que o acuam em grupo do lado de fora de suas habitações atingidas pela miséria, começam por recriminá-lo e responsabilizá-lo pelo acontecido, acusando-o de ter-Ihes dado esperanças ilusórias e prometido uma vitória fácil; depois passam a lançar-lhe acusações mais infamantes e distantes da realidade, como a de se ter abrigado dos tiros atrás das mulheres mortas, e por fim começam a lançar-lhe pedras. O jovem só é salvo pela intervenção de Rasseneur, que muito antes previra tal revés de sua popularidade e o abriga, aproveitando para discursar e apaziguar os companheiros, recobrando assim, às custas da queda sacrificial de Étienne, sua antiga posição de prestígio.

Mas é do outro lado que se encontra a reação mais interessante ao massacre, a qual- permite que o consideremos mais propriamente um sacrifício. Tendo optado por primeiramente narrar o terrível estado em que o evento lançou os trabalhadores, aumentando assim o choque provocado pelo contraste, no mesmo primeiro capítulo da sétima parte do livro em que o faz, Zola apresenta o júbilo dos burgueses em um contexto particularmente impressionante e no qual reencontramos um tema abordado no capítulo anterior deste trabalho: uma festa que comemora alegremente a vitória violenta sobre os opositores.

Estritamente, não é, e nem poderia ser em tal contexto histórico, a repressão violenta a cidadãos franceses o motivo explícito da festa, que comemora em realidade o noivado de Cécile e do sobrinho do diretor das minas Négrel. Entretanto, o narrador afirma diretamente que tal festa assume para os presentes a função de comemorar os recentes fatos, que lhes devolvem a paz e a segurança.

E eles têm razão, pois, se o sacrifício dos grevistas com que se alegram não foi suficiente para produzir uma unanimidade que reunisse de modo mais integrado os dois grupos, seu efeito no interior de cada um foi suficiente para que na prática tudo voltasse ao normal com a submissão derrotista dos trabalhadores que, após exíguas garantias de que não haveria represálias por parte da companhia, terminam por retomar o trabalho. Há, entretanto, um último evento sacrificial de grandes 
proporções no livro, o qual é de gênero bastante diverso. Falo do atentado cometido por Souvarine.

Zola constrói este personagem em grande medida segundo os moldes de um herói maldito romântico. Personagens de tal gênero - em uma tendência que representa algum avanço na percepção dos mecanismos sacrificiais - apresentam traços que os diferenciam e isolam das sociedades que os rodeiam, como é típico dos bodes expiatórios tradicionais; tal diferenciação, porém, é apresentada como um traço de singularidade que os distingue como superiores à coletividade medíocre que não os compreende. Isso contraria a unanimidade completa que justifica a exclusão sacrificial praticada pelas diversas comunidades, mas não rompe com sua lógica, o sacrifício permanecendo como algo necessário, embora sua função seja enobrecer o herói, o que assim permite um novo tipo de aproveitamento literário do fascínio que a vítima sacrificial sempre exerceu.

Zola certamente não adere a esse ponto de vista, mas Souvarine apresenta essas características, e sua condenação total da sociedade que o rodeia, bem como das tentativas relativamente moderadas de substituí-la por outros modelos igualmente moderados, apresenta analogias com a crítica cética do próprio autor, que por outro lado não exclui dela este próprio radicalismo prometeico. À parte isso, o personagem interessa a esta pesquisa por unir a esse demonismo romântico a adoção de muitos dos elementos sacrificiais típicos dos ideais revolucionários discutidos na introdução teórica deste capítulo, os quais, aliás, são os que o conduziram a essa solitária posição heroica.

Dois traços típicos do personagem que o distinguem fortemente do meio em que o vemos no romance são sua proveniência de uma classe abastada e sua nacionalidade estrangeira, que o colocam na típica posição do herói sacrificial que não pertence inteiramente à comunidade em que se insere. Além disso, como mencionado anteriormente, Souvarine segue as ideias de transformação violenta da sociedade defendidas por Bakunin com um fervor (caso possamos aplicar a expressão contraditória à sua atitude fria e distanciada) que o autor apresenta bastante cedo como uma espécie de culto a um deus da destruição. Ele acredita, de acordo com as 
linhas mais ingênuas do anarquismo, que uma nova humanidade emergiria dos escombros da antiga sociedade, de cuja iniquidade apenas a destruição completa poderia livrar a Terra. Para contribuir com este renascimento, em que todo o mundo deveria ser sacrificado por um futuro superior, ele assume a dupla disposição sacrificial de aceitar sem pesar a própria morte ao passo que busca a morte daqueles que impediriam seu ideal, aderindo assim aos movimentos terroristas russos. Ele e seus companheiros armam um atentado contra o Czar, malogram e, em decorrência, Souvarine deve assistir impotente ao enforcamento de sua amada, que participava da conspiração.

São esses trágicos eventos que marcam uma adoção ainda mais intensa do personagem de seus ideais sacrificiais, e ele assume as mortes de seus companheiros e de sua amada como um sacrifício pessoal, que, desembaraçando-o de laços afetivos que o pudessem fazer hesitar, o tornaria capaz de atuar com total decisão em sua luta futura.

São estas as disposições que se ocultam sob a superioridade distanciada do personagem que conhecemos como um operário fleumático, que espera pacientemente uma oportunidade de desferir um golpe contra a sociedade cuja destruição tanto almeja. Graças a elas ele concebe seu grande plano, e não hesita em se aproveitar da oportunidade oferecida pelos estragos na estrutura do elevador que descia à mina para, ampliando-os, provocar um acidente no momento em que o trabalho fosse retomado.

Com isso Souvarine visava provocar grandes prejuízos à companhia, e assim causar sua pequena ferida ao capital. A morte dos mineiros que fossem apanhados no acidente seria um sacrifício colateral que ele estava disposto a pagar - sendo interessante notar que uma vez mais no livro, o golpe que deveria se voltar contra a estrutura de exploração representada pela companhia recai com muito maior força sobre outras vítimas, no caso os mesmos que ela explora -, mas, mais que isso, constitui em alguma medida uma punição pela fraqueza dos trabalhadores, como ele insinua a Étienne sem revelar seus propósitos. 
Mas apesar de se crer inteiramente desembaraçado de empecilhos emocionais que o detivessem, há um último laço que Souvarine deve romper, singularizando assim - sacrifício impessoal que realizava e reforçando os toques trágicos de sua personagem. Tendo praticado sua sabotagem, o anarquista se pusera a observar a chegada dos trabalhadores que abandonavam a greve, cujo grande número o surpreendia. O que jamais poderia esperar, porém, era ver entre eles Étienne, que finalmente se entendera com Catherine e se decidira a retomar, também, o trabalho, com o fim de construir com ela uma vida, ainda que precária.

Em uma explosão de raiva que contraria sua atitude constante, em parte provocada pela capitulação particularmente agastante daquele que, bem ou mal, provocara e conduzira a greve, mas em parte também devida ao desejo de poupar o amigo à armadilha que armara com as próprias mãos, Souvarine o interpela e tenta afastá-lo aos empurrões. Mas ao compreender seus motivos, sua emoção se dissipa de um golpe, e ele abandona toda tentativa de detê-lo, isso por considerar que, quando há uma mulher na vida de um homem, ele está perdido. O paralelo entre a perda da própria amada, que considerava tê-lo fortalecido, e a fraqueza a que considerava que o amor levara o amigo é visivelmente o que o leva a encontrar a frieza para este último sacrifício, e despachar o outro para a provável morte com um indiferente aperto de mão.

Souvarine passa, então, o restante do dia a observar à distância a destruição provocada por sua sabotagem, para então partir sozinho, ao aguardo de uma nova oportunidade. Embora voluntário, seu afastamento completo de todos é o mesmo do bode expiatório expulso, cuja virtude de provocar catástrofes também mantém, tornando-o, na descrição final do narrador, uma figura quase mítica, a qual, a despeito do anonimato, estaria por trás de todo o temor de violência e desordem social por parte dos burgueses.

Ironicamente, é este o sacrifício com virtudes de reconciliação mais fortes, pois no afã de oferecer socorro às vítimas soterradas do acidente, operários, mestres de obras e engenheiros deixam de lado suas diferenças e se lançam a um esforço desesperado por alcançar os sobreviventes. Contudo, a reconciliação em si não é 
propriamente sacrificial, já que não se deve à perseguição conjunta a um bode expiatório, senão a um impulso de camaradagem e solidariedade, que não necessariamente é implausível, se bem que a ausência completa ao menos de uma tendência a buscar culpados por parte do grupo como um todo possa causar estranheza a um olhar girardiano.

Ainda assim, os esforços para lidar com a crise não se findam sem um último acompanhamento sacrificial, já que a companhia, que preferiu ocultar a sabotagem e assumir a catástrofe como um acidente, aproveita o acontecido para demitir aqueles que julgava mais perigosos e que supunha poderem estar envolvidos no atentado. Fora isso, Zola não narra esse elã de solidariedade, de que um dos lados seria tão edificante, sem um toque de ironia, presente na curiosidade dos burgueses, que iam contemplar o local do acidente como um plácido espetáculo, e em particular a estranha morte de Cécile, que tendo ido com os pais à casa dos Maheu para demonstrar sua caridade e perdão, acaba sendo estrangulada pelo père Bonnemorte, que antes fora impedido de levar este ato de ressentimento inconsciente até o fim, o que rompe por completo a ilusão de que os conflitos pudessem ter sido verdadeiramente superados.

Mas a situação fica mais clara após o término das operações de resgate, quando Étienne, o único dos quinze mineiros que permaneceram presos a sobreviver, revê pela última vez os companheiros de trabalho. Sua estadia sob a terra é uma verdadeira passagem pela morte, com fortes ressonâncias de uma descida mítica aos infernos.

Após uma difícil fuga das águas que inundavam as galerias, o herói, Catherine e seu rival Chaval se veem presos juntos em um exíguo refúgio que devem partilhar. Nessa situação extrema, a simplista relação triangular se vê levada ao limite e é logo forçada a um desfecho. Ainda de modo insuficientemente simétrico, o desejo de Chaval por Catherine é reavivado por ela estar com Étienne. Ela o percebe e, assustada, faz o que pode para evitar o conflito direto entre os rivais que afetam ignorar um ao outro, mas isso se torna impossível, pois Chaval, que graças ao acaso e à falta de escrúpulos se encontrava em posse de alguns recursos a mais para fazer face à 
situação de extrema escassez, se aproveita disso para provocar o rival e tentar forçar a jovem a aceitá-lo de volta.

Diante disso, uma fúria assassina desperta em Étienne, atribuída também ao alcoolismo hereditário que, mesmo sem que ele houvesse bebido, parece ser capaz de fazê-lo ultrapassar os limites, e após um breve confronto ele golpeia e mata o adversário, o que condena a ele e à Catherine a, daí em diante, conviver durante o tempo de seu confinamento com o cadáver, de que tentam se desembaraçar, mas que é reiteradamente trazido de volta pela água. Os dois passaram dias assombrados por essa presença, torturados pela fome e a escuridão, concretizando seu amor em uma única união sexual já no limite de sua resistência, após a qual Catherine perece nos braços do amante, perdendo por pouco o socorro que logo os alcança.

Deste modo, Étienne experiencia em um mundo subterrâneo, diversas vezes comparado ao ventre de um monstro vingativo, a morte sob três formas: a violência mal contida em si mesmo e que se volta para os outros mesmo contra sua vontade; a dolorosa perda da amada; e sua própria morte, de que não poderia ter chegado mais perto, sendo resgatado inane, envelhecido e com os cabelos tornados inteiramente brancos nesse curto período. Assim, esses eventos, tão realistas de um ponto de vista, aproximam-se, por outro lado, de uma passagem mítica pela morte, de cujo reino o herói regressa transfigurado e trazendo marcas que tornam sua visão profundamente impressionante para os demais, no caso a união da juventude e da velhice, pronto para se erguer a esferas mais elevadas. No último capítulo, após semanas de recuperação, Étienne passeia entre os ex-companheiros de trabalho de que se despede, e aos quais sua presença intimida devido àquilo por que passou, sendo descrito alternadamente como velho e jovem, sem que deixe de ser ressaltado que algum tempo antes aqueles entre os quais se movia o haviam lapidado, o que aproxima o episódio do regresso de um bode expiatório transfigurado à comunidade de seus sacrificadores. Ele partiria para Paris, onde a notoriedade que os acontecimentos ligados à greve e ao acidente Ihe conferia abriam para ele a perspectiva de uma carreira política, o que, mais uma vez, é tratado com um bom toque de ironia por parte de Zola, bem como as esperanças de reforma social que voltam a ganhar força no espírito do protagonista, 
agora assumindo formas ainda mais moderadas e se depositando, particularmente, em um futuro sindicalismo fortalecido.

Ainda assim, a cena final do livro, em que o protagonista parte, deixando para trás os companheiros que afinal foram inteiramente derrotados, abandonando por completo a greve sem obter qualquer uma de suas reivindicações, não deixa de apontar para a futura retomada dos conflitos. Na submissão de cada um entra grande dose de ressentimento, e o som de suas ferramentas sob a terra, que são como que ouvidos por Étienne, portam o simbolismo do trabalho de subversão social operado pela revolta dos oprimidos; de um vigor subterrâneo que lentamente germinaria, para enfim brotar com a força de um exército que renovaria a sociedade em ruínas e levaria o perverso deus que tantas vezes personificara a exploração capitalista no livro a definhar.

Certamente o tom algo eufórico do fim do romance se deve menos à visão do próprio Zola do que ao fato de serem as esperanças de Étienne, reiteradamente apresentadas como ingênuas, o filtro do discurso do narrador, o que confere a ele alguma ironia. Entretanto, que o conflito provisoriamente apaziguado seja apresentado como apenas latente, à espera da ocasião para eclodir com redobrada violência, permanece verdade. O desconforto e o medo da burguesia diante da possibilidade de que a violência que emprega de modo sistemático contra as classes trabalhadoras reflua e se volte contra ela é a situação concreta para a qual aponta o livro, e o fato de que os acontecimentos históricos subsequentes não tenham confirmado as previsões de uma transformação generalizada da sociedade pela ação direta dos trabalhadores não a torna menos real.

Assim, podemos considerar que Germinal, unindo uma representação literária realista a um colorido mítico, nos apresenta um momento representativo das lutas de classe dentro da sociedade industrialista como o que podemos considerar uma sucessão de ciclos vitimários dentro de um sistema sacrificial em crise, em que a incapacidade de legitimar suficientemente o sacrifício de cada bode expiatório faz com que este falhe em alcançar um grau suficiente de unanimidade para instaurar um período durável de paz interna, como Girard julga típico de nosso período histórico. 
Desses sacrifícios, cujo caráter improfícuo é acentuado pela inocência particularmente marcante da maioria de suas vítimas (em grande medida acidentais), termina por resultar um período de menor comoção social, mas não sem que o sistema de exploração econômica apresentado de modo sacrificial se mostre enfraquecido, do processo resultando também personagens isolados que, marcados pelo sacrifício pessoal, carregam traços do herói mítico tradicional.

\section{Denúncia e adesão ao sacrificialismo em Brecht}

Brecht é um autor formalmente refinado, dotado de uma profunda capacidade de representação do real, mas que, por vezes, assume a propaganda revolucionária de modo, talvez, excessivo. Em algumas de suas obras mais famosas, prega nada menos do que a desumanização dos adversários políticos e sua eliminação pela violência em nome da revolução. Ele não se restringe $a$ isso, mas igualmente ataca violentamente os defensores do pacifismo - os quais, como destaca o filme $\mathbf{Z}$, de Costa-Gavras, podem ser bodes expiatórios tanto de capitalistas quanto de comunistas - e, idealizando os revolucionários em um curioso contraste com sua típica lucidez, defende a resistência violenta mesmo quando sua única consequência prática for a morte dos revolucionários em nome da revolução futura.

Essas características mais questionáveis são bastante visíveis em Os fuzis da senhora Carrar $^{64}$. Nesta peça, uma mãe procura impedir que os filhos vão para a linha de frente na guerra civil espanhola e oculta os fuzis que haviam pertencido a seu marido, morto na luta contra a aliança nazifascista. Embora, possivelmente, não pudesse existir um adversário ao qual a necessidade de combate fosse menos questionável - mesmo o pacifista extremo que foi Gandhi apoiando o esforço de guerra inglês contra a Alemanha de Hitler - o modo como Brecht a representa nesta peça é bastante problemático. Em um espelhamento do discurso nazista, que comparava suas vítimas a pragas, os partidários de Franco são comparados a tubarões e à lepra, que devem ser extirpados sem hesitação. A posição de um simpático, mas equivocado, padre local que defende a paz é duramente combatida, a defesa da não resistência sendo apresentada como cumplicidade criminosa com o inimigo.

\footnotetext{
${ }^{64}$ BRECHT, Bertolt. Os fuzis da senhora Carrar. Em Bertolt Brecht Teatro completo. Rio de Janeiro: Paz e Terra, 1991, V. 6.
} 
Sem questionarmos a legitimidade da resistência aos falangistas, o autor destaca incessantemente não seu aspecto prático, mas o heroísmo dos mortos particularmente apelativo no caso da filha dos vizinhos, uma honrada e jovem professora que vai à luta por julgar que não poderia ensinar sob o regime que tomava o país -, assim incitando o público ao martírio.

Ao fim, o filho mais velho, que a mãe forçava a seguir pescando em lugar de ir para a guerra, é arbitrariamente morto pelos falangistas, o que tanto prova a desumanidade do inimigo quanto a ilusão de que a não resistência possa garantir a segurança de qualquer um. Desse modo, esta trágica morte é o sacrifício que reúne os personagens em conflito na unanimidade a favor da guerra, a mãe se convence de que sua atitude é egoísta e parte com o irmão caçula para o combate.

Já no irônico "Poema a um homem bom", o alvo é bem menos indiscutível que o nazifascismo. Nele é ao "homem bom", preocupado com a própria vida e mais ou menos neutro que Brecht promete uma "boa bala", já que essa mesma neutralidade significaria, na verdade, um apoio à ordem estabelecida e um consequente entrave à revolução.

Essas mesmas características estão presentes, de modo mais complexo, em uma peça bastante superior: A Santa Joana dos matadouros ${ }^{65}$. Nela, Brecht representa com impressionante força a violência da exploração capitalista, ainda mais escancarada em inícios do século XX (ao menos com relação a seu estado atual no interior dos países desenvolvidos).

O sacrificialismo é particularmente presente nesta obra. De um lado, a escolha da indústria da carne, além de servir para ilustrar realisticamente dinâmicas do mundo dos negócios, é particularmente adequada para simbolizar o sacrifício dos trabalhadores em nome do capital ao remeter para o sacrifício dos animais, e de outro, o diálogo direto da peça com a obra de Schiller, A donzela de Orléans, sobre Joana D'Arc, e a clara referência à santa no título e no nome da protagonista trazem explicitamente a ideia de martírio, ressignificada para o contexto da luta operária.

\footnotetext{
${ }^{65}$ BRECHT, Bertolt. A Santa Joana dos matadouros. Em: Bertolt Brecht Teatro completo. Rio de Janeiro: Paz e Terra, 1991, V. 4.
} 
Embora a produção de Brecht apresente influências da tradição religiosa e o autor tenha feito a famosa declaração de que a leitura que mais o influenciou foi a Bíblia, a representação direta que faz da religião em suas obras se restringe, em geral, a seus aspectos mais grosseiros. Em Santa Joana não é diferente, mas, como veremos, a questão se complexifica pela qualidade da obra.

O papel da religião na peça é o de instrumento ideológico voltado à contenção das massas exploradas, intencionalmente utilizado pelas classes dominantes. Além disso, porém, aspectos mais sutis da ideologia, enquanto distorção da apreensão da realidade e mecanismo inconsciente de autojustificativa são discutidos, principalmente por meio do personagem Bocarra.

Este grande especulador da carne recebe informações privilegiadas de influentes amigos de Wall Street, e, com base nessas informações, toma decisões muito acertadas do ponto de vista de seu lucro pessoal, mas devastadoras para o equilíbrio econômico de Chicago, onde o enredo se situa, e sobretudo para os trabalhadores. Essas decisões, porém, ele justifica para os outros, e cada vez mais para si próprio, como ditadas por escrúpulos morais. De início, por exemplo, afirmando que sua sensibilidade foi demasiadamente afetada pela visão, que evitara durante todo o tempo que se dedicara a seu ramo de negócios, de um vitelo sendo abatido, o milionário cede suas ações ao sócio por um preço predeterminado, antes disso levando o maior concorrente à falência e condenando grande número de operários à miséria. Deste modo, ele se livra de um negócio que sabia de antemão estar condenado a uma próxima crise pelo excesso do produto no mercado.

A protagonista Joana, por outro lado, é uma sincera militante do grupo Soldados de Deus, que com sopas e cantos vai aos trabalhadores em apuros, tentando convencê-los a abandonarem suas preocupações materiais e se voltarem para o espiritual. Frente à inutilidade de seus esforços, a corajosa jovem procura descobrir as causas materiais do sofrimento com que se depara - sempre ingenuamente, acreditando encontrá-las em atitudes pessoais dos ricos e poder resolvê-las pela mesma via -, confrontando diversas vezes Bocarra. A cada vez ela se compenetra mais da verdadeira extensão do mal imposto aos pobres e aparentemente conquista uma 
vitória junto a Bocarra, o qual, porém, sempre acreditando ceder caridosamente e com o próprio prejuízo à forte impressão que Joana lhe provoca, passa a usá-la como justificativa para as decisões arriscadas, mas vantajosas, que segue tomando em detrimento de todos os demais. É assim, por exemplo, que, supostamente atormentado pela visão dos desempregados que a heroína conduz até ele, Bocarra compra todo o estoque de carne acumulado e a produção das próximas semanas, o que deveria garantir a retomada do trabalho, apenas mais tarde revelando, como se não ligasse os fatos, que as noticias que recebera indicavam uma breve alta dos preços e recomendavam a compra de produto.

O que temos assim é, portanto, uma alegoria em que a sincera ideologia religiosa de Joana, à medida que se torna cada vez mais insustentável, serve de justificativa para o autoengano ideológico do homem de negócios, que cada vez mais verá na religiosidade um instrumento útil a seus interesses, mas não o reconhece e se crê, também, sincero.

A dada altura, outros homens de negócios, tanto menos hábeis no jogo financeiro quanto menos sutis em seu envolvimento com o campo ideológico do que Bocarra, mas conscientes da possibilidade de utilização da religião como instrumento de contenção da revolta popular que se acumula, vão aos Soldados de Deus, e negociam abertamente patrociná-los com esse fim. Joana, porém, os expulsa e, apenas então descobrindo que o desemprego prosseguia, também devido a ações praticadas por Bocarra sob sua influência, decide - mesmo por ter sido expulsa pelos companheiros após estragar a oportunidade de patrocínio - que permaneceria junto aos operários até a retomada do trabalho e partilharia seu destino.

É a esta altura que a resistência dos próprios operários entra em cena. Joana acreditava poder contribuir com suas ideias para a resolução de seus problemas, mas as pretensões a certo protagonismo por parte da jovem são ironicamente desfeitas, em favor dos sindicalistas comunistas. Estes, entretanto, são bastante idealizados, em um curioso contraste com a lucidez que domina a peça como um todo.

Esses abnegados personagens, sem caráter individual e que fazem apenas breves aparições, como se dirá mais à frente - no momento em que estão sendo 
conduzidos à prisão - dedicaram toda sua vida a lutar, não pelo próprio bem, mas pelo bem coletivo, são os que "sabem o que fazer". Para escândalo de Joana, afirmam que a única solução para os problemas dos trabalhadores é a violência, mas, curiosamente, ao menos por ora, essa violência parece ser menos a que poderiam praticar do que aquela a que deveriam se expor.

Uma greve geral se prepara para dar apoio aos trabalhadores desempregados da indústria da carne, mas para que o movimento tenha sucesso, estes não podem fraquejar e devem se manter nos pátios dos matadouros, que já vêm ocupando, não importa o que haja. É inverno, e eles não devem ceder ao frio, nem à violência policial, mesmo a polícia empregando não menos do que metralhadoras para dispersá-los. Seu sacrifício, e eis um grande sacrifício, não necessariamente trará uma vitória imediata, mas deve ser feito em nome da vitória futura.

Tudo malogra, porém, pois Joana, que fora incumbida de entregar aos trabalhadores de um dos matadouros a notícia de que os serviços básicos adeririam à greve, fraqueja e, sem esta informação, os trabalhadores se retiram, impossibilitando o movimento. A fraqueza traidora de Joana tem motivos ideológicos em um duplo sentido: por um lado ela abomina a violência - postura que, como já vimos, Brecht ataca sistematicamente - e por outro, utiliza essa aversão como uma desculpa para si própria, justificando sua desistência no momento em que a nevasca se intensifica, bem como a violência repressiva, como ditada exclusivamente por essa recusa de tomar parte na incitação à violência.

Entretanto, ela passa por uma intensa crise de consciência ao se retirar, e desaparece por algum tempo. Ressurge no momento em que Bocarra, e com ele o mercado de carne, aparentemente alcançam o apogeu, o capitalista encontrando a saída para a crise extrema em que lançara o negócio ao unificar os concorrentes em um conglomerado e propor a destruição de boa parte da produção (novo sacrifício simbólico de bois que representa o sacrifício imposto aos trabalhadores e consumidores). Dá-se também então a união com a força religiosa dos boinas pretas, 0 que concretiza um império e consolida uma nova ordem unânime, contra a qual a voz de Joana é a única a se erguer. 
A heroína, abatida e à beira da morte após o período que passou desaparecida, rejeita a ideia de uma ajuda invisível por parte de Deus e, finalmente, assume a necessidade de violência, não apenas contra os poderosos como contra os que defendem tal concepção de Deus ${ }^{66}$ : "Por isso se alguém aqui embaixo diz que Deus existe/Embora não esteja à vista/E que invisível é que ele ajuda/Deviam bater na calçada a cabeça desse alguém/Até matar" ${ }^{\prime 67}$. Ela se recrimina e vitupera a nova aliança, que, não obstante, cala sua voz e quer fazê-la mártir de sua causa, entoando hosanas enquanto ela morre. Deste modo, a morte de Joana é um sacrifício, sobre o qual há duas interpretações contraditórias. Os negociantes e os boinas pretas efetuam um verdadeiro ocultamento mitológico, apagando os sinais de sua participação na morte da vítima e convertendo-a em um símbolo sagrado que será uma das bases da nova ordem que fundam, enquanto os espectadores verão na morte da protagonista uma consequência da violência capitalista e uma metonímia do sacrifício dos trabalhadores, junto aos quais ela finalmente consegue se posicionar verdadeiramente. Assim, é interessante notar como a denúncia contra o discurso ideológico capitalista e religioso na peça se dá, justamente, na forma da revelação da verdade violenta sob a criação de um mito e da sacralização de uma vítima.

Brecht constrói a morte de Joana de fato como um martírio, mas não um martírio revolucionário típico, nos moldes da jovem professora de Os fuzis da senhora Carrar. Trata-se, antes, de um martírio da tomada de consciência. São suas contradições ideológicas que a conduzem a um gradual sacrifício não da própria vida, mas de seu modo de ser, o qual culmina, ainda assim, com sua morte trágica e que não alcançará seu verdadeiro significado no interior da peça, já que os que a testemunham a distorcem. Mas o autor não permite que sua obra se conclua com esse aparente malogro, pois o suposto triunfo de Bocarra e dos seus é contestado por notícias referentes à catástrofe econômica da crise de 1929, as quais entrecortam os hinos que entoam ao fim da peça. Desse modo, a forte obra representa uma dura denúncia do sacrificialismo capitalista e do encobrimento ideológico de suas vítimas, profetizando o

\footnotetext{
${ }^{66}$ Note-se que grande parte das tendências religiosas não conservadoras poderiam bem concordar com esta frase, exceto, talvez, no que diz respeito à defesa da violência. A teologia da libertação, por exemplo, defende que a verdadeira vivência da fé exige o empenho humano da transformação concreta da sociedade.

${ }^{67}$ Op. cit. 124.
} 
futuro surgimento de uma outra sociedade que emergirá de suas ruínas. Esta nova sociedade, porém, se fundará sobre o autossacrifício dessas mesmas vítimas, o qual Brecht vê como necessário e heroico.

Mais uma vez, é difícil rejeitar por completo a validade deste autossacrifício, desde que interpretado no sentido positivo de martírio empregado por Juan Luís Segundo, já discutido. Mais problemática é sua contrapartida na forma de sacrifício do inimigo, o qual, sob a forma despreocupada como Brecht o defende nos textos aqui mencionados, é inaceitável, mas que também não pode ser condenado a priori, considerando-se que recusá-lo absolutamente representa a manutenção da violência já instaurada.

É uma difícil aporia, que se torna ainda mais difícil diante do risco, inúmeras vezes concretizado de que, como afirmam Adorno e Horkheimer ${ }^{68}$, as revoluções terminem por criar formas ainda mais opressoras de poder. O próprio Brecht, em sua obra mais tardia, mostra-se bastante desiludido com o resultado objetivo das lutas a que tanto se dedicou, assumindo uma posição, em grande medida, de afastamento.

Mais provavelmente, estas dificuldades não poderão jamais ser resolvidas. 0 único que nos resta é estarmos atentos à onipresença da lógica sacrificial e, a cada momento histórico, buscar nos posicionar ao lado dos bodes expiatórios do presente, procurando os melhores caminhos práticos para tanto. Não há receitas prévias, e cada um deverá se ater ao próprio julgamento, consciente do risco de aderir involuntariamente a mecanismos sacrificiais e assumindo as próprias escolhas.

\footnotetext{
${ }^{68}$ HORKHEIMER, Max e ADORNO Theodor W. Dialética do esclarecimento. Rio de Janeiro: Jorge Zahar, 1985.
} 


\section{Conclusão}

E assim seguimos, a passos desproporcionais e um tanto quanto erradios, a trilha do sacrifício, tal como se revela e oculta nas obras literárias, desde os impérios antigos até a sociedade capitalista do século XX que em linhas gerais ainda é a nossa. Não será, talvez, animador nem surpreendente, notar que a violência do sacrifício não se faz menos presente hoje em dia do que há milhares de anos e mesmo parece muito mais visível. Eis, porém, algo ambíguo, pois se de um lado não podemos negar que as vítimas do presente possam ser ainda mais numerosas que as do passado, por outro, justamente o fato de que as possamos ver e reconhecer atualmente com mais clareza é um avanço que não pode ser subestimado.

É grande a diferença entre o poema mítico no qual com algum esforço podemos vislumbrar o sacrifício do monarca que ocupa o cimo do império (quase confundindo-se com o sistema mítico e idolátrico de divindades que o justifica) enquanto mal haverá algum indício daquele dos escravos que o sustêm, e a peça que apesar de qualquer limite - denuncia sistematicamente o sacrifício dos operários explorados e ainda lança luz sobre o próprio mecanismo de ocultamento que deveria recobri-lo. Não, é claro, que se trate de um avanço linear ou muito menos de apresentar as obras contemporâneas como superiores às do passado, mesmo porque vimos como também elas possuem seu próprio sacrificialismo, para não falar do fato de que as poucas aqui selecionadas se opõem a outras que podem ser tão sacrificiais quanto qualquer uma já produzida. O que ocorre é que essa maior sensibilidade para o sacrifício reflete uma tendência ética fundamental que se desenvolveu a partir do Ocidente e hoje engloba todo o mundo, a qual podemos definir como o enfraquecimento cada vez maior da unanimidade mítico-ideológica que apresenta as vítimas como culpadas ou quando menos o sacrifício como necessário e inevitável. Isto representa um grande passo, pois é uma condição necessária para qualquer denúncia ou mesmo para o reconhecimento das reivindicações das próprias vítimas, que sem isso simplesmente seriam reprimidas sem que se questionasse a justiça dessa violência. 
Para Girard, este avanço se deve à especificidade das narrativas cristãs da morte de Jesus, que revela o mecanismo sacrificial que o conduziu à cruz, o condena e demonstra sua analogia com todas as manifestações desta dinâmica universal nas sociedades humanas. Essa é, de modo geral, também a opinião que adoto, embora não o tenha desenvolvido mais profundamente neste trabalho. Entretanto, é essencial ressaltar que isso não significa absolutamente que o cristianismo seja livre do sacrifício, pois como todas as culturas ele desenvolveu suas formas específicas de sacrificialismo, suas linhas antissacrificiais sendo, aliás, minoritárias ao longo da história, tanto que boa parte das obras estudadas neste trabalho foram produzidas no contexto cristão e as que mais se afastam do sacrificialismo se opõem a ele, ainda que herdem as conquistas de suas vertentes libertárias.

$\mathrm{Na}$ verdade, se o foco da pesquisa houvesse sido este, poderíamos observar como na tradição literária dos últimos quinhentos anos, por exemplo, se deu um crescimento constante de obras em que se manifesta o desconforto com os elementos sacrificiais da tradição literária, com diferentes tentativas de dar-lhes outras soluções, como vimos em Gargantua, assim como de obras que pretendem trazer uma denúncia direta daquilo que podemos considerar o sacrificialismo real de suas sociedades, isso não sem que se deparem com limites, haja retrocessos ou mesmo que, ao contornar certas formas do sacrificialismo, recaiam em outras igualmente problemáticas. Mas nosso objetivo não era acompanhar essa evolução, senão algumas das formas como a literatura trabalha, de modo inconsciente, as relações entre o sacrifício e a estruturação do poder, no que me deparei com grande variedade de obra a obra, mas também com linhas de continuidade.

Alguns dos resultados a que cheguei foram inesperados, como, aliás, seria normal em qualquer pesquisa honesta. Um desses foi a construção da hipótese de que, nas obras épicas, por serem fruto de culturas (e principalmente de certas camadas sociais dentro destas culturas) em que a ambivalência do sagrado - que nos mitos originários se concentraria nos mesmos personagens nascidos das vítimas transfiguradas - causa desconforto ou mesmo escândalo, o sacrifício tende a se dividir em dois: um cuja prática é positiva, e a vítima possui traços predominantemente negativos, outro cuja prática é culpável e a vítima possui traços predominantemente 
positivos. Ao se consumar de modo mais ou menos completo segundo o caso, esse sacrifício duplo do herói e de seus inimigos possui todas as virtudes pacificadoras do sacrifício básico girardiano, além disso correspondendo muito bem às necessidades ideológicas de culturas bélicas imperialistas, em que a disposição para o autossacrifício heroico dos guerreiros em nome de sua pátria, em torno da qual se constitui o culto aos mortos de guerra, e a justificativa da destruição e conquista do inimigo externo em nome do Império constituem um duplo pilar sacrificial de seu éthos e um poderoso elemento de sua unidade.

Essa hipótese também permitiu considerar que o interessante conceito de sacrifício dos sacrificadores, que Franz Hinkelammert criou e considera específico do mundo cristão, tem como sua condição o sacrifício duplo, pois a prática do sacrifício mau de vítimas inocentes é um dos principais traços negativos da vítima condenada, e uma das principais justificativas para o sacrifício positivo que sofrerá. Isso, entretanto, não é exclusividade de culturas cristãs, mas já se esboça em todas aquelas nas quais se inicia o processo de dissociação da ambivalência do sagrado.

É interessante notar que essas mesmas tendências se fazem presentes no discurso revolucionário dos séculos $X I X$ e $X X$, ainda que em princípio pudéssemos supor que, sendo a literatura épica a expressão do poder imperialista estabelecido e em expansão, suas características deveriam ser muito diversas daquelas do discurso que pretende a subversão da ordem presente. Para os revolucionários, o sacrifício duplo se constitui no ideal de morrer pela revolução ao passo que se elimina aqueles que a entravam, esses últimos sofrendo o sacrifício dos sacrificadores, já que é sua defesa de uma sociedade repressiva e de exploração extremada dos inocentes, ou seja, de uma ordem sacrificial, o que torna justa sua destruição em nome da revolução.

Claro que isso não significa de modo algum que teria havido uma transferência de antigas tendências sacrificiais, outrora presentes no discurso ligado ao poder estabelecido, para seus atuais opositores. Em realidade, elas permanecem vivas na ideologia capitalista ${ }^{69}$, sobretudo naquela imperialista, nacionalista e militarista que

\footnotetext{
69 Aliás, em seu livro, Hinkelammert segue a continuidade entre o sacrifício dos sacrificadores na cristandade, a que chama de inversão antissacrificial - por converter aqueles que, como Cristo, se
} 
alcançou seu auge no período das obras estudadas, as quais, seja como crítica direta do sacrificialismo, seja como manifestação de seu discurso, nos permitem vê-las em ambos os lados. Assim, sem desejar de modo algum apagar as diferenças concretas entre os discursos e práticas conservadores e revolucionários, é preciso reconhecer como em grande medida, neste e em outros pontos, eles estão presos em uma violenta relação de duplos miméticos.

Já menos direta é a presença dessas formas específicas do sacrificialismo nas obras cômicas aqui estudadas, o que se deve ao fato de que nelas a ambivalência do sagrado permanece menos dissociada do que nas outras tendências literárias que estudamos. Por isso, em particular o sacrifício duplo não está presente, pois não há o sacrifício do herói, a não ser - pelo menos em Rabelais - sob sua forma transfigurada. Melhor dizendo, já que aqui certamente não falamos de eventos reais transfigurados em uma narrativa mítica: o que podemos encontrar são cenas em que se configura quase por completo a unanimidade sacrificial do "todos contra um", chegando à beira do assassínio coletivo em que o herói seria a vítima, mas este escapa ileso graças a peripécias que na vida real não poderiam ter lugar.

Mas como sabemos, o sacrifício duplo não é necessário para a fundação ou refundação da ordem, sendo o sacrifício da vítima única e sua repetição cíclica, aliás, sua matriz, e este está bastante presente na literatura cômica. Muito frequentemente, em obras que representam uma ação em um meio privado, as quais aqui não foram estudadas, os conflitos e mal entendidos entre os personagens acabam se resolvendo às custas de um deles, como no Tartuffe de Molière, a crise dando lugar a um modelo de paz não problemático. Nas obras que analisamos, o mesmo princípio é aplicado a um cenário bem mais amplo, englobando a totalidade da sociedade representada, sendo designadas e expostas ao ridículo as vítimas cujo sacrifício deveria por fim à crise e restaurar a ordem ideal.

Outro elemento que se fazia presente nas três vertentes literárias estudadas, embora bem mais visível em certas obras do que em outras, é a idolatria. Devo admitir

opunham ao sacrificialismo vigente em praticantes do sacrifício nefasto que deveria ser punido - e a perseguição nos países capitalistas daqueles que pretendem uma transformação da sociedade. 
que, embora desde o início pretendesse articular este conceito com a reflexão girardiana quanto ao sacrifício, o desenvolvi ao longo deste trabalho de modo pouco sistemático, mencionando-o sem grande desenvolvimento ao início do primeiro capítulo, aqui e ali ao longo das análises seguintes, para alcançar uma formulação um pouco mais trabalhada apenas no terceiro capítulo. Talvez esta conclusão seja uma boa oportunidade para retomar rapidamente a definição do conceito de um modo mais ordenado e explicitar com mais clareza sua aplicação nas obras analisadas.

O ídolo sacrificial é tudo aquilo que um indivíduo, e principalmente uma comunidade, considera um valor elevado o bastante para justificar a morte de uma pessoa ou grupo. De início, embora intuindo uma ligação mais direta, julgava que a discussão desse conceito de sacrifício idolátrico seria antes um paralelo à do mecanismo de bode expiatório, mas de fato sua relação é maior do que isso. O ídolo coletivo se origina do sacrifício fundador junto com a cultura e poderíamos identificálo, para usar tardiamente um conceito que bem poderia ter figurado nas páginas anteriores, com a lei que mata ${ }^{70}$ : as prescrições e tabus cuja desobediência é punida com a morte ou a exclusão da sociedade e os ritos que exigem o sacrifício de novas vítimas. Essas instituições sacrificiais originárias são mimeticamente aceitas pela comunidade como um todo e se tornam, com o devido apoio mítico e simbólico, seu referencial último, seu ídolo, a execução de suas leis sendo praticada por ela como um todo, quer diretamente ou por delegação de poder.

Com o desenvolvimento das sociedades, outros ídolos vão se destacando deste conjunto que, basicamente, poderíamos identificar como a cultura como um todo, tais como: a ideia de pátria, a lealdade à monarquia, o império, a adesão a determinada crença religiosa, ou, mais recentemente, ideias como as de progresso, o mercado ou a revolução. Quando em nome de qualquer um destes ídolos cria-se a exigência de uma guerra, da conquista ou escravização de um povo, bem como do autossacrifício dos que os aceitam, isso é um sacrifício em um sentido muito próximo ao do mecanismo sacrificial estudado por Girard, pois também depende do mimetismo coletivo e até

\footnotetext{
${ }^{70}$ A respeito deste conceito de Paulo, muito retomado atualmente, inclusive pela chamada nova esquerda, ver HINKELAMMERT, Franz. A maldição que pesa sobre a lei. São Paulo: Paulus, 2012.
} 
mesmo possui as mesmas virtudes de apaziguamento de conflitos internos e reforço da unidade de uma sociedade.

Nas análises literárias que compõem esta pesquisa vimos, embora nem sempre o texto o explicitasse, unidas ou separadas, a idolatria do império ou da fé como um dos elementos centrais na maioria das obras estudadas; no segundo capítulo, talvez possamos considerar os interesses de Atenas, que determinam as posições de Aristófanes pró ou contra a guerra, como o ídolo que lhe indicava as vítimas para o ataque sacrificial, e certamente para Rabelais seu ideal de monarquia justa o era; enquanto no terceiro capítulo víamos em conflito o ídolo do capital e o da revolução violenta.

Mais uma vez, é importante ressaltar que a análise destes elementos nas obras estudadas não significa condená-las em nome de algum critério arbitrariamente imposto a elas. Trata-se de ressaltar um aspecto realmente significativo em sua composição literária, e cuja presença ao longo de toda a tradição ressalta sua importância. É um aspecto problemático, ligado à violência e à opressão, mas assim como não nos passaria pela cabeça - falando de modo geral - condenar toda a cultura humana e sua História, mas sim discuti-las, reconhecendo suas misérias e suas formas de lidar com elas na esperança, quem sabe, de que assim possamos contribuir para minorá-las; o mesmo vale para a literatura que as representa e que deste modo mostra seu valor essencial para esta discussão. Como toda obra humana, a literatura se liga ao que a humanidade tem de bem e de mal, mas, em maior grau que a maioria dessas obras, sua própria natureza contém um questionamento a seu respeito e convida à reflexão. 


\section{Bibliografia}

ADORNO, Theodor, W. Notas de literatura I. São Paulo: Duas Cidades/Editora 34, 2003.

Notas sobre literatura - Obra completa, v.11. Madri: Akal, 2009.

ADORNO, Theodor W. \& Horkheimer, Max. Dialética do esclarecimento. Rio de Janeiro: Jorge Zahar Editor, 1985.

AGAMBEN, Giorgio. O Reino e a Glória: uma genealogia teológica da economia e do governo. São Paulo: Boitempo, 2011.

ANCHIETA, José de. $\mathbf{O}$ auto de São Lourenço. Rio de Janeiro: Ediouro, s/d.

ANÔNIMO, La chanson de Roland, tradução para o francês moderno por FABRE, Josephhttp://www.litteratureaudio.com/livre-

audio-gratuit-mp3/anonyme-la-chanson-de-roland.html

ANSPACH, Mark R. Édipo mimético. São Paulo: É Realizações, 2012.

ASSMANN, Hugo (org.) René Girard com teólogos da libertação - um diálogo sobre ídolos e sacrifícios. Petrópolis: Editora vozes de Piracicaba: Editora UNIMEP, 1991.

ARRIGUCCI, JR., Davi. Enigma e comentário - ensaios sobre literatura e experiência. São Paulo: Cia das Letras, 1987.

Outros achados e perdidos. São Paulo: Cia das Letras, 1999.

AUERBACH, Erich. Ensaios de literatura ocidental. São Paulo: Duas Cidades/Editora 34, 2007.

Figura. São Paulo: Ática, 1997. 
Mimesis - a representação da realidade na literatura ocidental. São Paulo: Perspectiva, 1987.

BAKHTIN, Mikhail. A cultura popular na Idade Média e no Renascimento. São Paulo: Hucitec, 2010.

Marxismo e filosofia da linguagem. São Paulo: Hucitec, 2015.

Problemas da poética de Dostoiévski. São Paulo: Forense Universitária, 2005.

BANDERA, Cesáreo. "Despoja e despida": a humilde história de Dom Quixote reflexões sobre a origem do romance moderno. São Paulo: É Realizações, 2012.

Mimesis conflictiva - ficción literaria y violencia en Cervantes e Calderón. Madri: Editorial Gredos, 1975.

BENJAMIN, Walter. Obras escolhidas - Magia e técnica, arte e política. São Paulo: Brasiliense, 1993.

A origem do drama trágico alemão. Belo horizonte: Autêntica, 2011.

BOSI, Alfredo. Céu, inferno - ensaios de crítica literária e ideologia. São Paulo: Ática, 1998.

Dialética da colonização. São Paulo: Cia das Letras, 1992,

Ideologia e contraideologia. São Paulo: Cia das Letras, 2010.

O ser e o Tempo da Poesia. São Paulo : Cia das Letras, 2006.

CAMPBELL, Josef. O herói de mil faces. São Paulo, Pensamento, 2014.

CANDIDO, Antonio. O discurso e a cidade. São Paulo: Duas Cidades, 1998. 
A educação pela noite. São Paulo: Atica, 1987.

Tese e antítese. São Paulo: Companhia Editora Nacional, 1978.

CARPEAUX, Otto Maria. História da literatura ocidental. Rio de Janeiro: Edições O Cruzeiro, 1966.

CHEVAlIER, Jean \& GHEERBRANT, Alain. Dicionário de Símbolos : mitos, sonhos, costumes, gestos, formas, figuras, cores, números. Rio de Janeiro: José Olympio, 1998.

DOURADO, Autran. Armas \& corações. Rio de Janeiro/São Paulo: Difel, 1978. O artista aprendiz. Rio de Janeiro: José Olympio,1989.

DRUMMOND, Carlos. "Reflexões sobre o fanatismo", em Passeios na ilha. São Paulo: Cosac Naify, 2011.

DUPUY, Jean-Pierre. Petite métaphysique des tsunamis. Paris : Seuil, 2005.

EAGLETON, Terry $\mathbf{O}$ problema dos desconhecidos - um estudo da ética. Rio de Janeiro: Civilização Brasileira, 2010.

Doce violência: a ideia do trágico. São Paulo: Editora UNESP, 2013.

FRANZ, Marie Luise von. A interpretação dos contos de fada. São Paulo: Paulus, 1990.

FRY, Northrop. Anatomia da crítica. São Paulo: Cultrix, 1973. 
GEERTZ, Clifford. A interpretação das culturas. Rio de Janeiro: Editora Guanabara, 1989.

GIRARD, René. O bode expiatório. São Paulo: Paulus, 2004.

Coisas ocultas desde a fundação do mundo. São Paulo: Paz e Terra, 2018.

A crítica no subsolo. São Paulo/Rio de Janeiro: Paz e Terra, 2011.

Dostoiévski: do duplo à unidade. São Paulo: É realizações, 2011.

Eu via Satanás cair do céu como um raio. Lisboa: Instituto Piaget, 2002.

Je vois Satan tomber comme l'éclair. Paris : Grasset, 1999.

Mentiras românticas e verdade romanesca. São Paulo: É Realizações, 2009.

Rematar Clausewitz. São Paulo: É Realizações, 2011.

A rota antiga dos homens perversos. São Paulo: Paulus, 2009.

Shakespeare: Teatro da inveja. São Paulo: É Realizações 2010.

A voz desconhecida do real - uma teoria dos mitos arcaicos e modernos. Lisboa: Instituto Piaget, 2002

A violência e o sagrado. Rio de Janeiro/São Paulo: Paz e Terra,1998.

GOLDMANN, Lucien. Dialética e cultura. Rio de Janeiro, 1967.

A sociologia do romance. Rio de Janeiro/São Paulo : Paz e Terra, 1990.

HINKELAMMERT, Franz. As armas ideológicas da morte. São Paulo: Editora Paulinas, 1983. 
A maldição que pesa sobre a lei. São Paulo: Paulus, 2012.

. Sacrifícios humanos e sociedade ocidental: Lúcifer e a Besta. São Paulo:

Paulus, 1995.

HOMERO. The Iliad (tradução Samuel Butler) disponível em áudio em https://librivox.org/the-iliad-by-homer-translated-by-samuel-butler/ The Odyssey (tradução Samuel Butler) disponível em áudio em https://librivox.org/the-odyssey-by-homer/

HÖSLE, Vittorio. L’idealisme objectif. Paris: Les Éditions Du Cerf, 2001.

Woody Allen: filosofia del humor. Barcelona: Tusques Editores, 2002.

JAMESON, Fredric. 0 inconsciente coletivo - a narrativa como ato socialmente simbólico. São Paulo: Ática, 1992.

Marxismo e forma - Teorias dialéticas da literatura no século XX. São Paulo: Hucitec, 1985.

JOHNSEN, William A. Violência e modernismo: Ibsen, Joyce e Woolf. São Paulo: É Realizações Editora, 2011.

LACLOS, Choderlos de. Les Liaisons Dangereuses. Paris: Garnier-Flamarion, 1971.

LEWIS, C. S. Alegoria do amor - um estudo da tradição medieval. São Paulo: É Realizações Editora, 2012. 
LOPES, Paulo César Carneiro. Utopia cristã no sertão mineiro: uma leitura de "A hora e vez de Augusto Matraga" de João Guimarães Rosa. Petrópolis: Vozes, 1997.

Dialética da iluminação - estudo sobre Corpo de Baile. São Paulo: Nankin, 2014.

LÖWY, Michael. Walter Benjamin: aviso de incêndio - uma leitura das teses "obre o conceito de história". São Paulo: Boitempo Editorial, 2005.

LÖWY, Michael e NAÏR, Sami. Lucien Goldmann ou a dialética da totalidade.

LUKÁCS, György. Ensaios sobre literatura. Rio de Janeiro: Editora Civilização Brasileira, 1965.

O romance histórico. São Paulo: Editora Boitempo, 2011.

Teoria do romance. São Paulo: Livraria duas cidades e Editora 34, 2000.

MALRAUX, André. La condition humaine. Paris: Librairie Gallimard, 1933.

MARCUSE, Herbert. Eros e civilização: uma interpretação filosófica do pensamento de Freud. Rio de Janeiro: Zahar, 1999.

MAZZARI, Marcus Vinícius. Labirintos da Aprendizagem - pacto fáustico, romance de formação e outros temas de literatura comparada. São Paulo: Editora 34, 2010.

MERQUIOR, José Guilherme. Razão do poema - ensaios de crítica e de estética. São Paulo: É Realizações Editora, 2013. 
OLIVEIRA, Manfredo Araújo de. Ética, direito e Democracia. São Paulo: Paulus, 2010.

PACHECO, Ana Paula. Lugar do mito - narrativa do processo social nas Primeiras estórias de Guimarães Rosa. São Paulo: Nankin, 2006.

RABELAIS, François. Gargantua, disponível em áudio em:

http://www.litteratureaudio.com/livre-audio-gratuit-mp3/rabelais-francoisgargantua.html Pantagruel, disponível em áudio em: http://www.litteratureaudio.com/livreaudio-gratuit-mp3/rabelais-francois-pantagruel.html

RICOEUR, Paul. História e verdade. Rio de Janeiro: Companhia Editora Forense, 1955. Ideologia e utopia. Lisboa: Edições 70, 1991.

Philosophie de la volonté. Paris: Aubier, 1949.

Philosophie de la volonté II - finitude e culpabilité, comprenant deux textes: I'homme faillible, la symbolique du mal. Paris: Aubier, 1988.

Tempo e narrativa, 3v. Campinas: Papirus Editora, 1997.

RIGHI, Maurício G. Pré- História \& História: As instituições e as ideias em seus fundamentos religiosos. São Paulo: É Realizações, 2017.

ROCHA, João Cezar de Castro. Culturas Shakespearianas: teoria mimética e os desafios da mímesis em circunstâncias não hegemônicas. São Paulo: É realizações, 2017. 
Machado de Assis: por uma poética da emulação. Rio de Janeiro: Civilização Brasileira, 2013.

SCHWARZ, Roberto. Martinha versus Lucrécia - ensaios e entrevistas. São Paulo: Cia das Letras, 2012.

Que horas são? São Paulo: Cia das Letras, 1989.

SEGUNDO, Juan Luis. O homem de hoje diante de Jesus de Nazaré . São Paulo: Edições Paulinas, 1985. V. I - fé e ideologia.

SEVCENKO, Nicolau. Literatura como missão: tensões sociais e criação cultural na Primeira República. São Paulo: Brasiliense, 1989.

SUNG, Jung Mo. Idolatria do dinheiro e direitos humanos: uma crítica teológica do novo mito do capitalismo. São Paulo: Paulus, 2018.

TERÊNCIO. O eunuco. em: Plauto e Terêncio/A comédia latina. Coleção Universidade. Rio de Janeiro: Edições de Ouro, s/d.

VAZ, H.C.Lima. Ética e cultura - Escritos de filosofia II. São Paulo: Loyola, 1988. Escritos de filosofia III - filosofia e cultura. São Paulo: Edições Loyola, 1997.

VIRGÍLIO. LA Eneida. Traduzido por OCHOA, Eugenio de, disponível em áudio em: https://librivox.org/la-eneida-por-virgilio/ 
ZIZEK, Slavoj. Violência. São Paulo: Boitempo, 2014.

ZOLA, Émile. Germinal. Disponível em áudio em

http://www.litteratureaudio.com/livre-audio-gratuit-mp3/zola-emile-germinal.html 